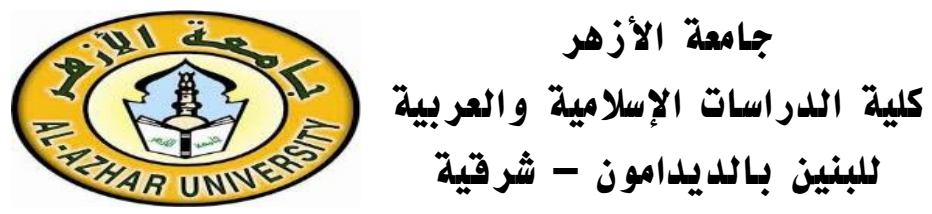

$$
\text { الوسطية وعلاقتها بالاجتهاد النقهي }
$$

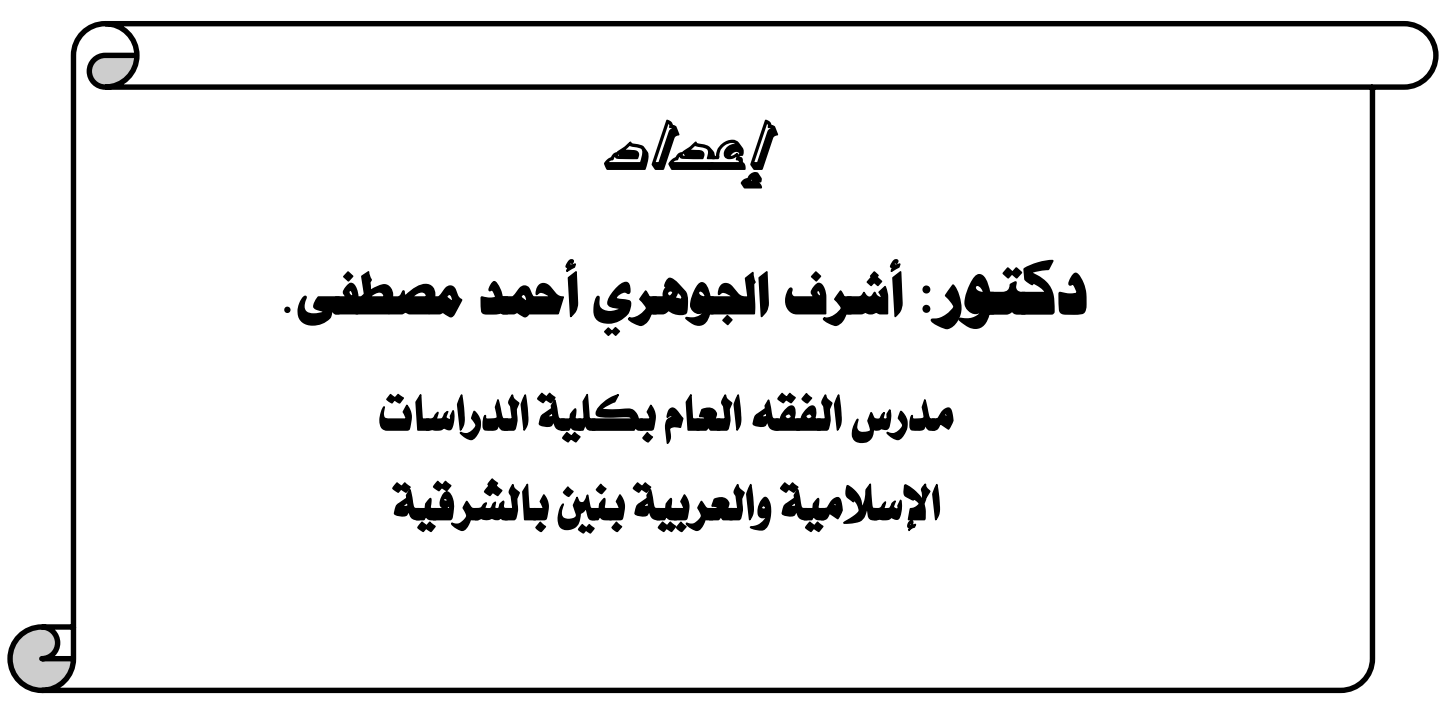

$$
\text { المؤتمر العلمي الدولي الأول }
$$

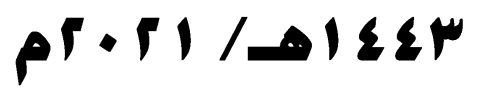


$\square$

$-1 \cdot N r-$ 
الوسطية وعلاقتها بالاجتهاد الفقهي (المذهب الشافعي) نموذجًا

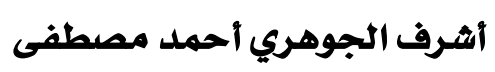

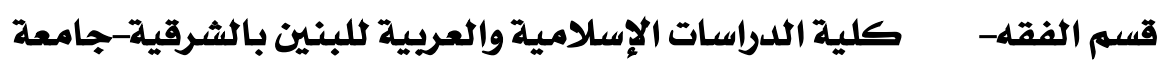

الأزهر. مدينة: فاقوس. الدولة: جمهورية مصر العربية.

ملخص البحث

اللحمد لله رب العالمين والصلاة والسلام على آثرف الخلق وسيد المرسلين، أما بعد:

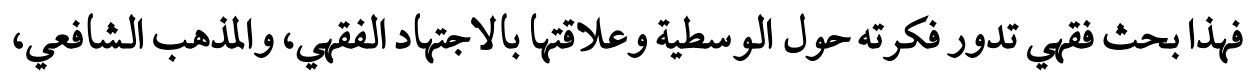

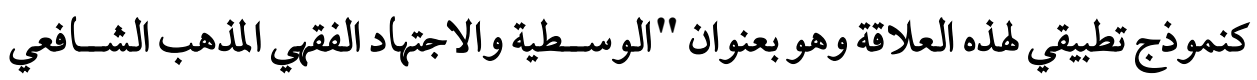

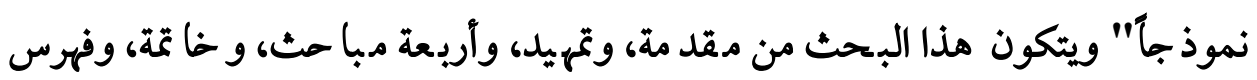

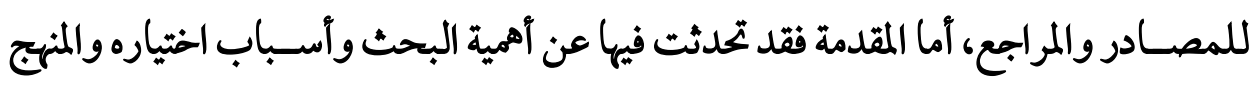

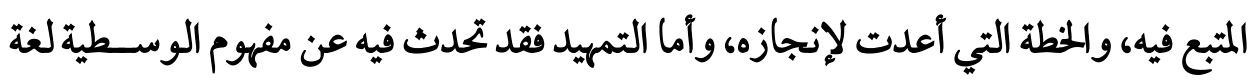

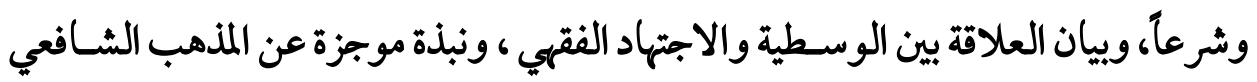

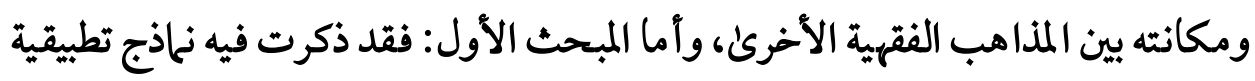

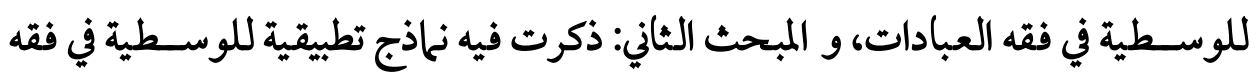

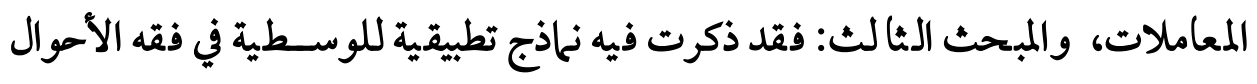

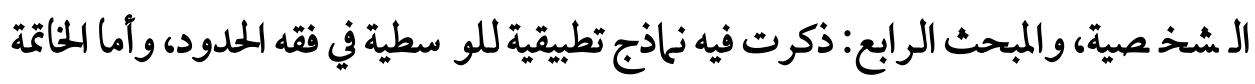

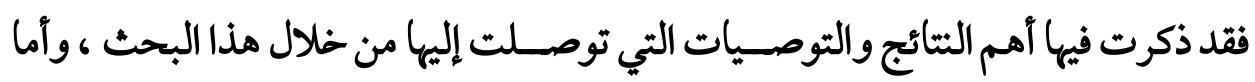
فهرس المصـادر والمراجع: فيشـتمل علئ المصـادر والمراجع التي اعتمدت عليها في كتابة هذا

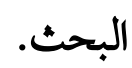
الكلمات المفتاحية: الوسطية-الاجتهاد الفقهي-المذهب الشافعي. 
Moderation and its relationship to jurisprudence (Shafi'i school of thought) as a model

\section{Ashraf El Gohary Ahmed Mostafa}

Department of jurisprudence- Faculty of Islamic and Arab Studies for Boys in Sharqiya - Al-Azhar University.

City: Faqous - State: Arab Republic of Egypt

Research Summary

Praise be to God، the Lord of the Worlds، and peace and blessings upon the most noble of creation and Messenger. The preface deals with the importance of research the reasons for its choice، the method used and the plan prepared for its implementation. The preface describes the concept of intermediation as a language and a law' indicating the relationship between intermediation and jurisprudencer and a brief overview of the Shafi 'i school of thought and its place among schools of thought، The first is described as applied models of mediocrity in jurisprudential jurisprudencer the second is mentioned as applied models of mediocrity in jurisprudential jurisprudence، the third is mentioned as applied models of mediocrity in personal jurisprudencer the fourth is mentioned as applied models of mediocrity in jurisprudential jurisprudence، and the conclusion is stated as the most important findings and recommendations it reached through this research As for the indexes: they include an index of Quranic verses ، an index of hadiths and antiquities، an index of jurisprudential rules' an index of sources and references' and an index of topics. Keywords: moderation - jurisprudence - Shafi'i school 


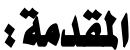

الحمد لله رب العالمين أكمل لنا الدين، وآتم علينا النعمة ورضي لنا الإسلام دينا، اللهم ربنا لك الحمد كله ولك الشكر كله وإليك يرجع الأمر كله ، والصلاة والسلام علئ خاتم الأنبياء، و سيد الأصفياء، وإمام العلماء، وأكرم من مشتى تحت أديم السماء، سيدنا محمد نبي الرحمة، الداعي إلى سبيل ربه بالمكمة والموعظة الحسنة، وخير نبي بعث إلى خير أمة أخرجت للناس،

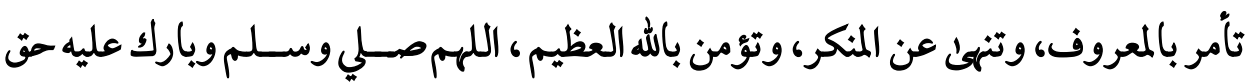
إلى أن يســـــوم الـــــــاس

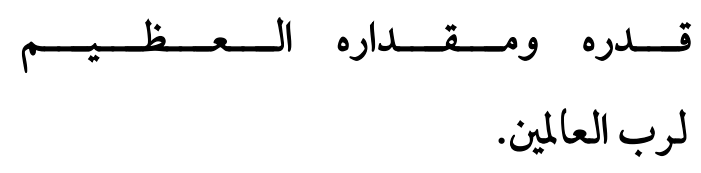
أَمَّهَ بَعْدُ:

فإن الإسـلام دين جمع بين الدذيا والآخرة، والعلم والعمل، وا لملادة والروح، والعبادة والمعاملة، فهو دين الوسـطية والاعتدال، وإعطاء كل ذي حق حقّه،ولقد كان من رحمة الله تعالى بالأمة الإ سلامية أن جعل الو سطية والاعتدال شعار آكيزاً ملما عن غيرها من الأممفي

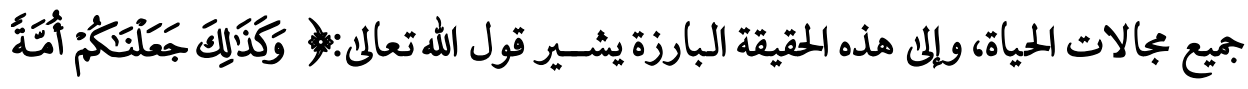

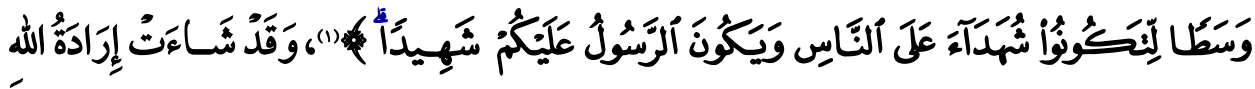

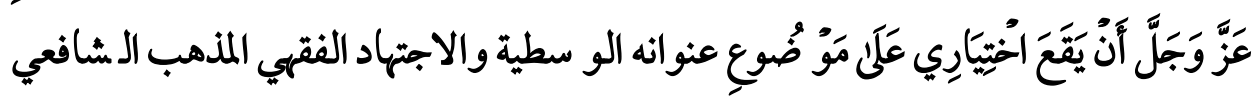
نموذجاً ،لمشاركة في المؤتمر العلمي الدولي الأول والذي بعنوان الو سطية تأصيلاً وتطبيقاً وأثر ها في تحقيق الأمن الفردي والاجتماعي، والذي تنظمه كلية الدراسـات الإسـاميلامية والعربية للبنين بالديدامون شرقية، بالتعاون مع كلية الدراسـات العليا في العلوم الشر-عية العية

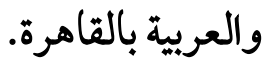

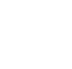

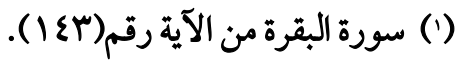


أسباب الاختيار:

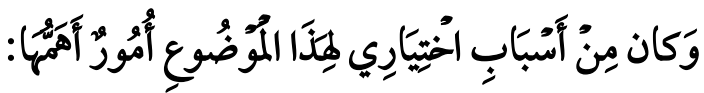

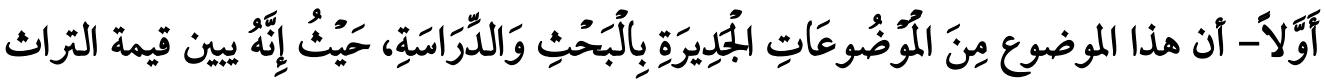
الفههي الإسلامي وتأصيل احترامه في نفوس المسلمين من خلال الفهم الصحيح للأدلة الشرعية المعتبرة.

ثانياً- أن هذا الموضوع يبين مكانة الإمام الثافعي بين الأئمة المجتهدين، ومذهبه الفقهي الاجتهادي الوسطي المعتدل من خلال ذكر النحاذج التطبيقية في جميع أبواب الفقه المختلفة جمعاً بين النظرية والتطبيق.

ثالثاً-- عدم وجود دراسة علمية وافية تتناول هذا الموضوع تأصيلا وتطبيقا. منهج البحث:

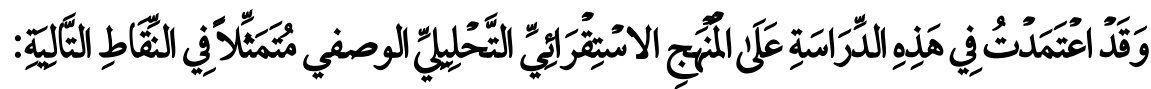

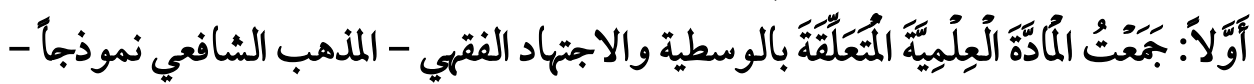

$$
\text { من الَكتُبْ الأَصِيلَةِّ. }
$$

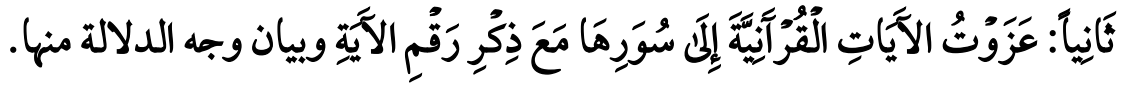

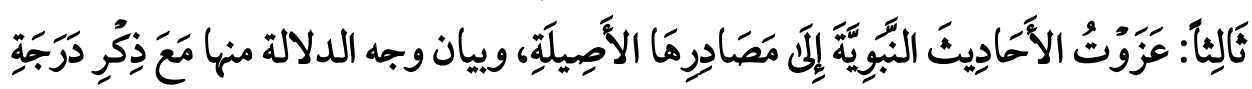

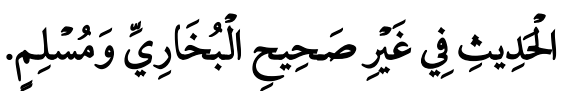

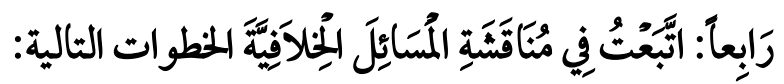

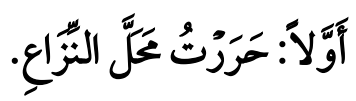

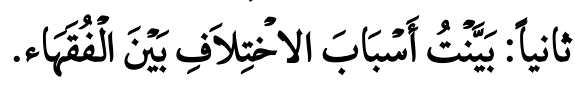

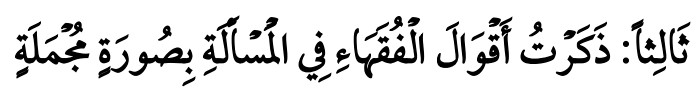

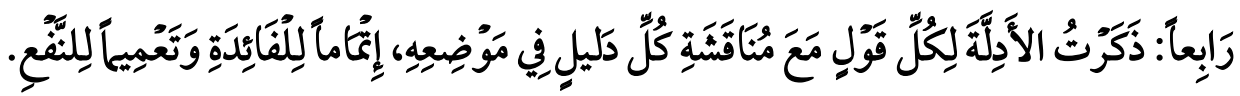

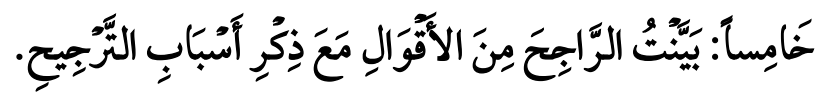


خطة البحث:

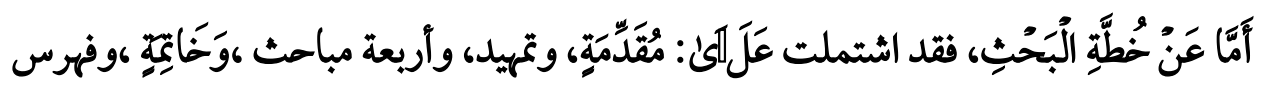
للمصادر والمراجع.

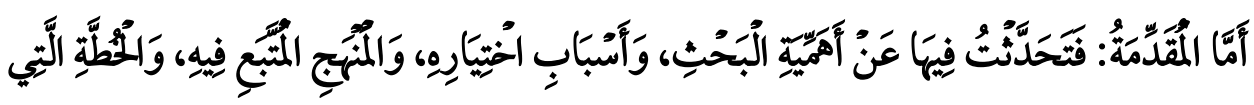
أَعِدَّتُ لإِنججَازِهِ. وأما التمهيد: وعنوانه التعريف بالكلمات المفتاحية التي تكون منها عنوان البحث.

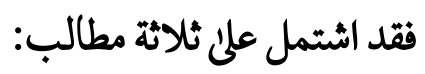
المطلب الأول: مفهوم الوسطية لغة وشرعاً. المطلب الثني: العلاقة بين الوسطية والاجتهاد الفقهي. المطلب الثالث: نبذة موجزة عن المذهب الثافعي وييان مكانته بين المذاهب الفقهية الأخرى'.

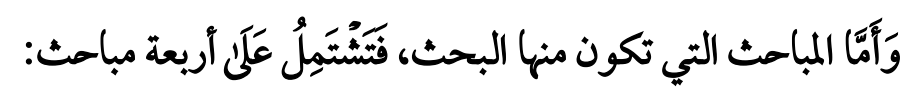
المبحث الأَوَلُ: نحاذج تطبيقية من الوسطية في فقه العبادات. المبحث الثلني: نحاذج تطبيقية من الوسطية في فقه المعاملات. المبحث الثالث: نماذج تطبيقية من الوسطية في فقه الأحوال الشخصية. المبحث الرابع: نماذج تطبيقية من الوسطية في فقه الحدود. وأما الخاتمة: فتشتمل على أهم التتائج والتوصيات التي توصلت إليها في نهاية البحث. وأما فهرس البحث، فيشتمل على المصادر والكتب التي اعتمدت عليها في كتابة هذا البحث. 


\section{التمعيد}

\section{التصريف بالكلمات المتتاحية التي فمون منها عنوان البعث}

لما كان الحكم علني الشيء فرع عن تصوره، فإن معالجة هذا المبحث، سوف تشتمل على

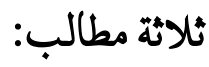

المطلب الأول: مفهوم الوسطية لغة وشرعاً.

المطلب الثاني: العلاقة بين الوسطية والاجتهاد الفقهي.

المطلب الثالث: نبذة موجزة عن المذهب الشافعي ومكانته بين المذاهب الفقهية الأخرى'.

\section{المطاب الأول}

\section{مثهوم الوبسيلة لفة وششرماً}

لما كانت الوسـطية لما معنيان: أحدهما في اللغة، والآخر في الشرع، فإن معالجة هذا المطلب

$$
\begin{aligned}
& \text { سوف تشتمل على فرعين: } \\
& \text { الفرع الأول: مفهوم الوسطية لغة. } \\
& \text { الفرع الثاني: مفهوم الوسطية شرعاً. }
\end{aligned}
$$




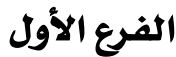

\section{مفهوم الوسطية لغة}

الوسطية لغة: التوسط والاعتدال اسملما بين طرفي الشيء وهو منه(1)، والوسط من كل شيء: أعدله (r)، ووسط الشيء: ما بين طرفيه("). الفرع الثاني

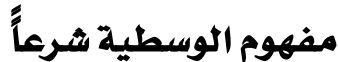

الوسطية في عرف فتهاء الشافعية هي: التوسط بين شيئين()، كالتوسط بين القرب والبعد؛(0)، وبين الطول والقصر()، وبين الاختصار والتطويل ()()، وبين المهر والإسرار،(()، ويين السرف

(') ابن منظور محمد بن مكرم بن علنه، أبو الفضل، جمال الدين ابن منظور الأنصاري الرويفعى الإفريقى (المتوفن: IIIII)-

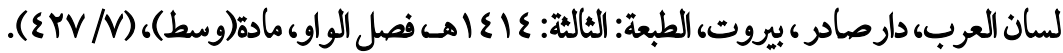
(') ابن فارس أحمد بن فارس بن زكرياء القزويني الرازي، أبو الحسين(المتوفن: 90 بهـــ)- بجمل اللغة، مؤ سسة

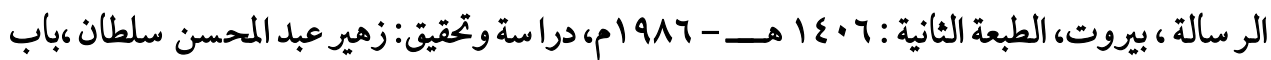
الواو والسين وما يثلثها، مادة(وسط)،(1/ / ع ج ه). (r) ابن منظور - لسان العرب، فصل الواو، مادة(وسط)، (V/ צY ). (") إمام الحرمين عبد الملك بن عبد الله بن يوسف بن محمد الجويني، أبو المعالي، ركن الدين، الملقب بإمام الحرمين

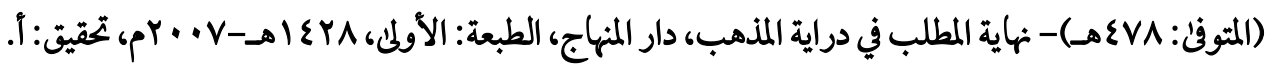

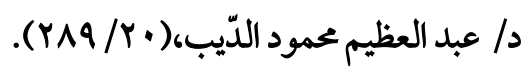

(•) الماوردي أبو الحسن علي بن محمد بن محمد بن حبيب البصري البغدادي، الشهير بالماوردي(المتوفن: • 0ع مهـــ-

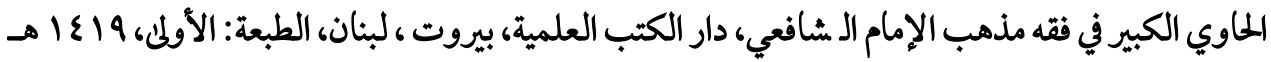

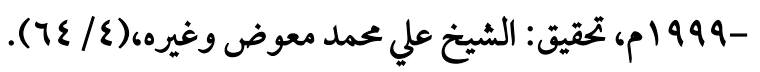

(1)أبو يجيح السنيكي زكريا الأنصاري زكريا بن محمد بن أحمد بن زكريا الأنصاري، زين الدين أبو يجيح السنيكي

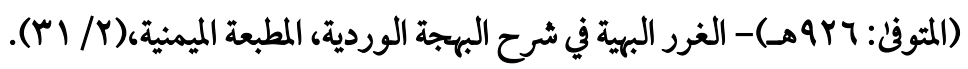

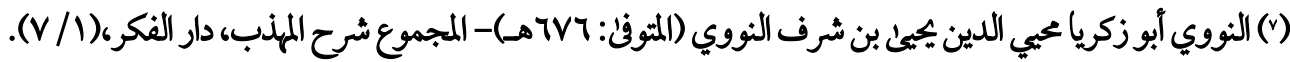
(^) الرملي شمس الدين محمد بن أبي العباس أحمد بن مزة شهاب الدين الرملي (المتوفن: ع ـ · اهـــ) - نهاية المحتاج 
والتقتير،(1)، ويين الجودة والرداءة، ويين اليســار والإعســار (()، ويين القلة والكثرةة(1)، ويين والصغر (i)، ويين السفل والعلو (o)، ويين الغالب والنادر و(1) ،وغير ذلك.

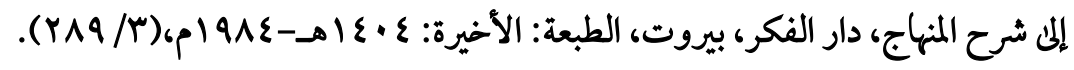

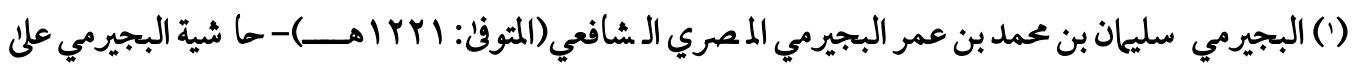

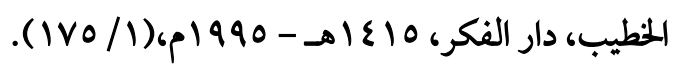

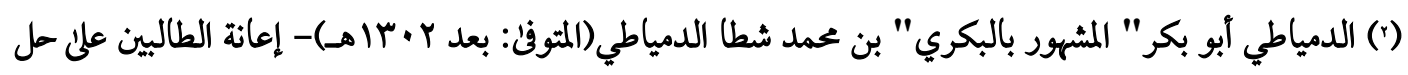

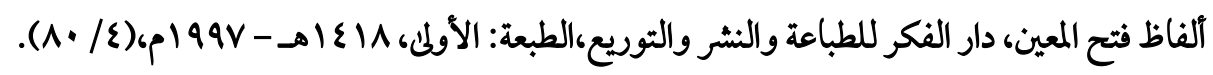

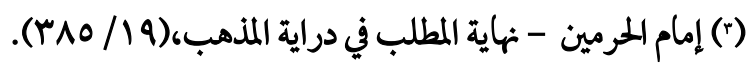

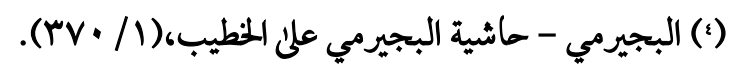

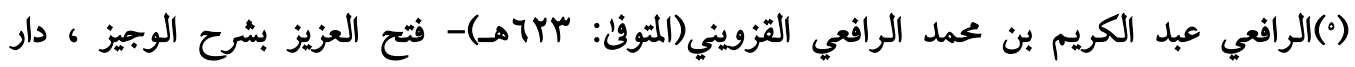

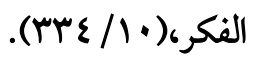

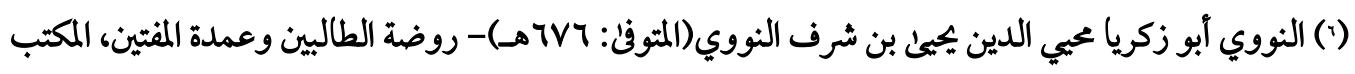

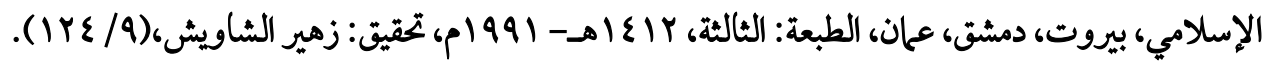




\title{
المبلب الثاني
}

\section{الملاوقة بين الوسطية والاجتهاد الفقهي}

لما كان المكم على الثيء فرع عن تصوره، فإن معالجة هذا المطلب سوف تشتمل على فرعين:

$$
\text { الفرع الأول: مفهوم الاجتهادلغة وشرعاً. }
$$

الفرع الثاني: العلاقة بين الوسطية والاجتهاد الفتهي.

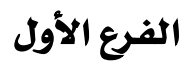

مفهوم الاجتهاد لغة وشروعاً

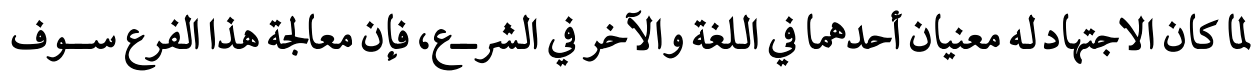

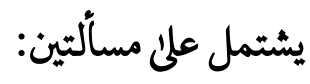

المسألة الأولى: مفهوم الاجتهاد لغلة.

المسالة الثانية: مفهوم الاجتهاد شرعاً.

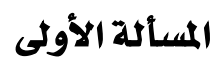

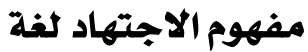

الاجتهاد لغة: بذل الوســ في طلب الأمر (1)، يقال : اجتهد في الأمر بذل وسـعه وطاقته في طلبه ليبلغ بههوده، ويصل إلى نهايته (").

\author{
المعالة الثانية \\ مفهوم الاجتهاد شرعاً \\ الاجتهاد شرعا:" هو استفراغ الفقيه الوسع لتحصيل ظن بحكم شرعي".
}

(1) ابن الأثير بجد الدين أبو السعادات المبارك بن محمد بن محمد بن محمد ابن عبد الكريم الشيباني الجزري ابن الأثير

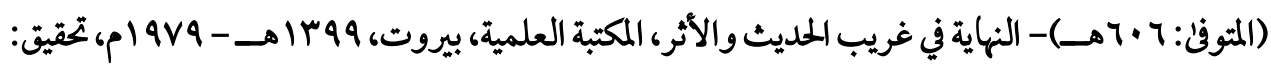

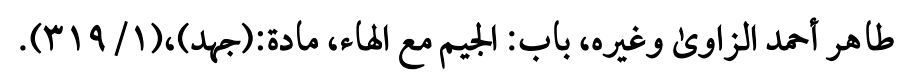

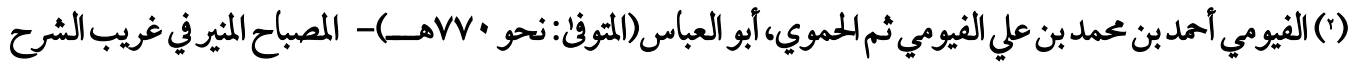

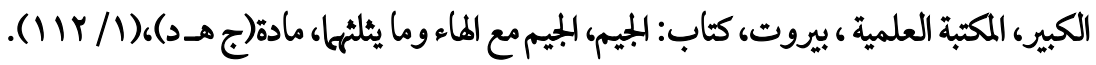

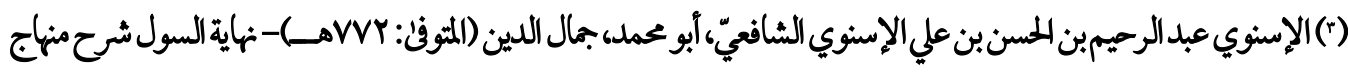

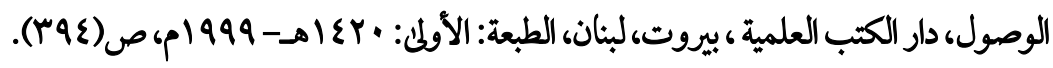




$$
\text { العلاقة بين الوسطية والاجتهاد الفقهي الفري الثاني }
$$

من خلال التعريف الشرعي للو سطية في عرف فقهاء الشافعية يتبين مدى العلاقة الوثيقة بين الو سطية والاجتهاد الفقهي، فلقد كانت الو سطية تلازم فقهاء الـ شافعية بـصفة خا صة، وباقي الفقهاء المعتدلين والموثوق فيهم بصـفة عامة، وهم يعالجون جميع الموضسوعات الفقهية في جميع أبواب الفقه المختلفة، وســوف يظهر ذلك واضـحاً جلياً من خلال ذكر النهاذج التطبيقية في العبادات، والمعاملات، والأحوال الشخصية، والمدود، والله ولي التوفيق"). 


\section{المطلب الثالثه}

نبذه موجزة عن المذهب الشافعي ومكانته بين المذاهب الفقهية الأخرى

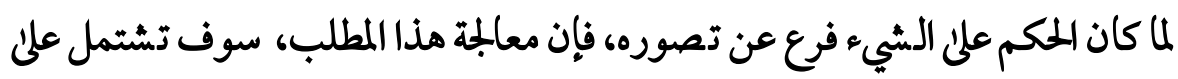

ثلاثة فروع

الفرع الأول: التعريف بمؤسس المذهب الشافعي.

$$
\text { الفرع الثاني: أصول المذهب الشافعي. }
$$

الفرع الثالث: مكانة المذهب الشافعي بين المذاهب الفقهية الأخرىن.

\section{الفرعالاول}

\section{التعريف بمؤسس المذاب الثافي الثيان}

اسمه: هو محمد بن إدريس بن العباس بن عثلان بن شافع بن السائب ابن عبيد بن عبد يزيد بن هاشم بن المطلب بن عبد مناف، القرشي المطلبي الشافعي.

$$
\text { كنبه: كنبه: الشافعي }
$$

مولده: ولد رضي الله عنه بمدينة غزة بفلسطين سنة خمسين ومائة.

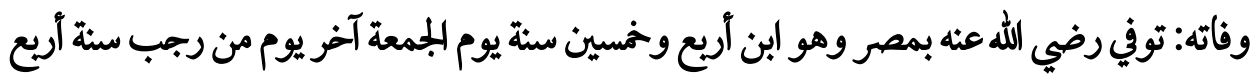
وماثتين، ودفن بعد العصر من يومه بالقرافة الصغرئ، وقبره يزار بها بالقرب من المقطم. مناقبه: كان الشافعي كثير المناقب جم المفاخر منقطع القرين، اجتمعت فيه من العلوم بكتاب

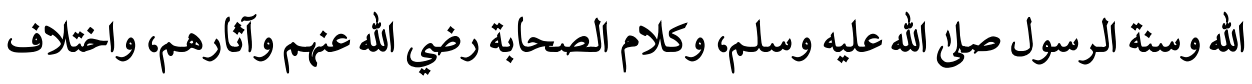

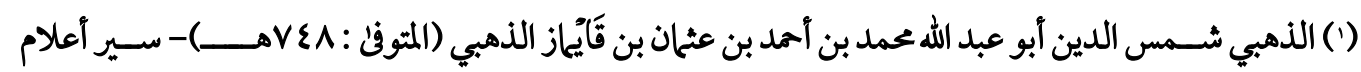

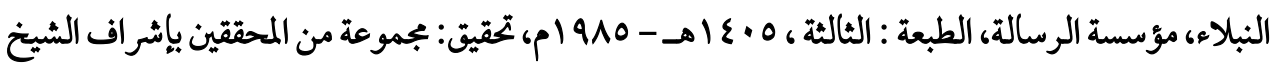

$$
\text { شعيب الأرناؤوط،(· / م). }
$$


أقاويل العلماء وغير ذلك من معرفة كلام العرب واللغة والعربية والشعر مالميتمع في غيره، حتى قال أحمد بن حنبل رضي الله عنه: ما عرفت ناسخ المديث ومنسوخه حتى جابل جالست

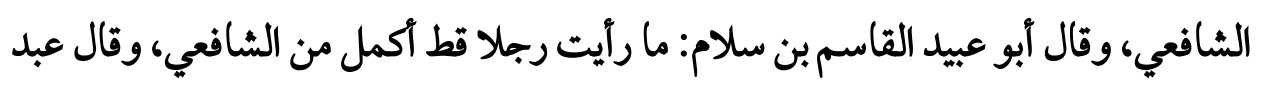
الله بن أحمد قلت لأبي: أي رجل كان الثافعي فإني سمعتك تكثر من الدعاء له، فقال: يا بني،

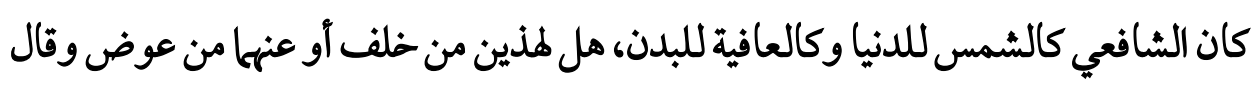

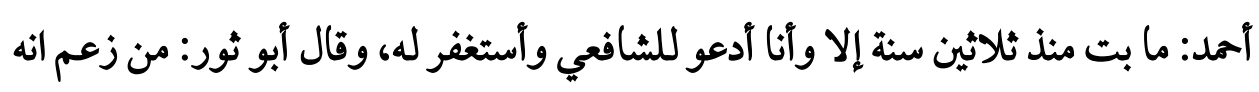

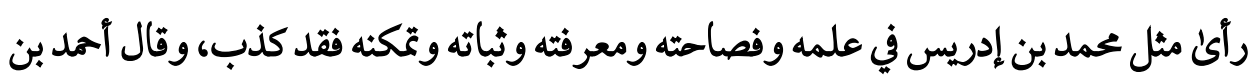

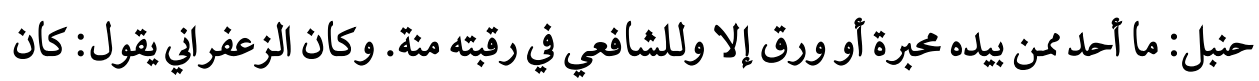

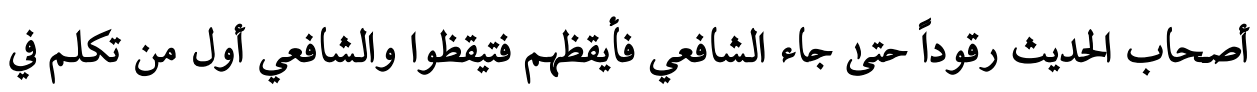

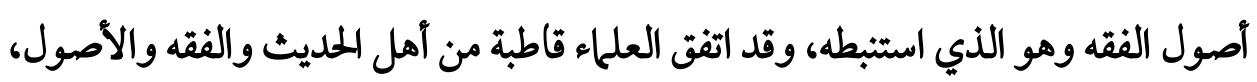

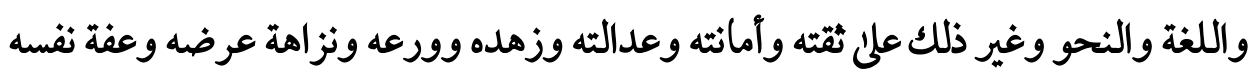
وحسن سيرته وعلو قدره وسخائهة).

مكانته بين الأئمة: هو أحد الأئمة الأربعة عند أهل السنة، وإليه نسبة الشافعية كافة.

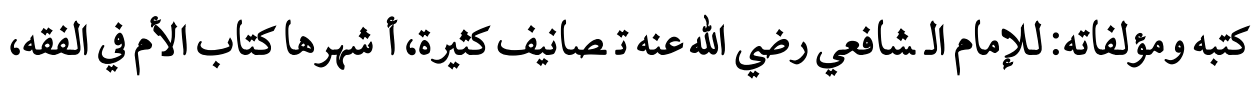

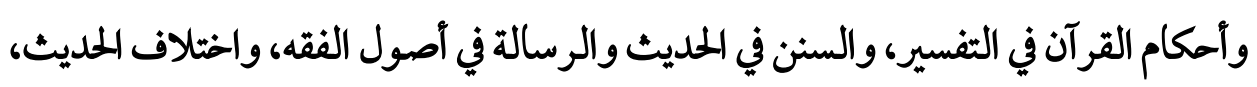

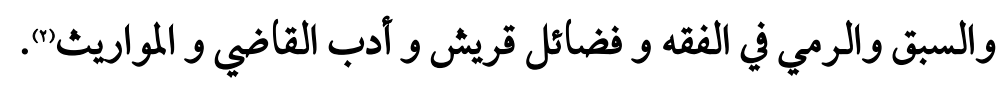

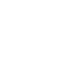

(1) ابن خلكان أبو العباس شــس الدين أهمد بن محمد بن إبراهيم بن أبي بكر ابن خلكان البرمكي الإربلي(المتوفن:

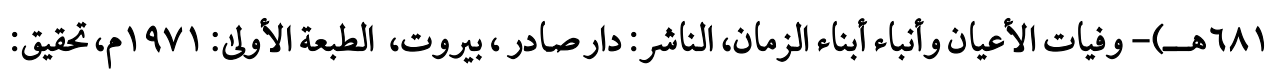

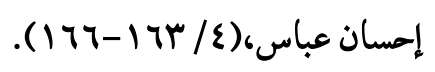

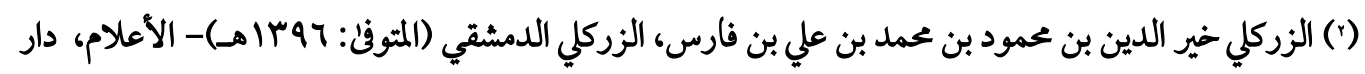

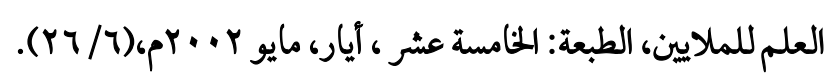




\section{الثرعالثاني \\ أصول الملاثهب الثماشيمي}

إن أصــول المذهب الشـافعي التي بني عليها، قد بينها الإمام الشـافعي بنفسـهـ في كتابه الأم، حيث جاء فيه ما نصـهـ" والعلم طبقات شـتـى الأوله: الكتاب والسـنة إذا ثبتت السـنة، ثم الثانية: الإجماع فياليس فيه كتاب ولا سنة، والثالثة أن يقول بعض أصحاب النبي ،صلن الله عليه وســلم، ولا نعلم له مخالفأ منهم، والرابعة اختلاف أصــحاب النبي ، صـلى الله عليه وسلم، في ذلك، الخامسة: القياس على بعض الطبقات ولا يصار إلى شيء غير الكتاب والسنة وهما موجودان وإنها يؤخذ العلم من أعلى" (1). وجاء في موضع آخر ما نصه:" والأصل كتاب، أو سنة، أو قول بعض أصحاب رسول الله - صـلنا الله عليه وسـلم ، أو إجماع الناس، قال: لا يكون أصـل أبداً إلا واحداً من هذه

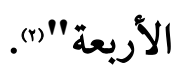

ومما سبق يظهر جلياً آن الإمام الشافعي رضي الله عنه بنى مذهبه بناءاً محكلا، وذلك آنه كان اعتحاده على كتاب الله وسنة رسوله والنظر الصحيح من الاجتهاد الراجع إلى الكتاب والسنة وترجيح أشبه المذاهب إلى الكتاب والسنة، وهذا هو الأصل الصحيح القوي الذي يتم البناء عليه إلا أنه قد يعرض له ما يعرض لغيره من البشر ممن ليس بمعصوم من الغفلة والنسيان فأحالنا تصريح قوله على أن ما يصح من آقوال النبي صلنى اللهعليه وسلم فهو مذهبه، فلم يترك لعائب عيباً، ولا لمتتقد من حساده انتقادآ، فرضي الله عنه (r).

(') الشافعي أبو عبد اللهحمد بن إدريس بن العباس بن عثلان بن شافع بن عبد المطلب بن عبد مناف المطلبي القرشي

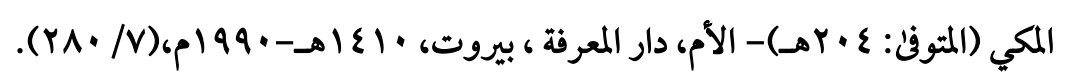

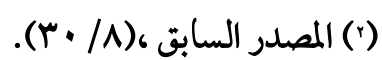

(r) أبو القاسـم شهاب الدين عبد الرمن بن إسـاعيل بن إبراهيم المقدسي الدم ششقي المعروف بأبي شـامة (المتوفن:

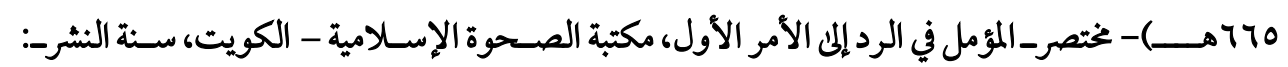


ومن خلال النصين السابقين يمكن القول بأن أصول المذهب الشافعي تتمثل في الكتاب

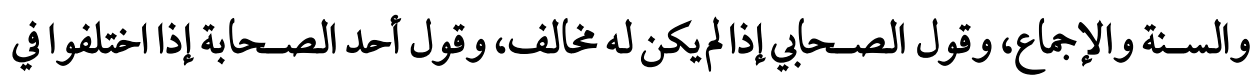
المسألة محل البحث، والقياس، ومن الملاحظ في النص السابق آن الإمام الشافعي آنزل السنة

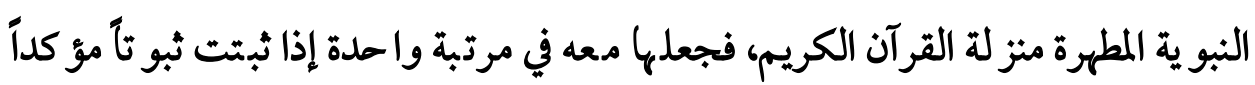

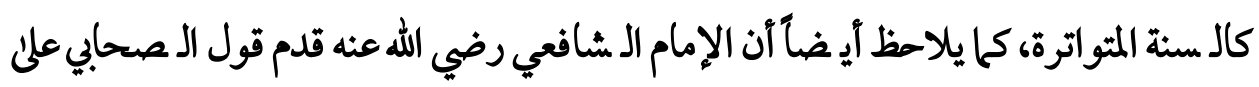
القياس، ومن جميع ما سبق يتخح جلياً مدئ و سطية واعتدال المذهب الشافعي في معالجة

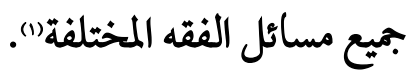

\section{الفرع الثالث}

مكانة المذهب الشافعي بين المذاهب الفقهية الأخرى الفيان

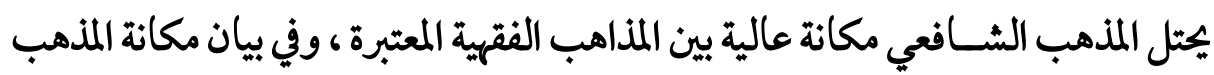

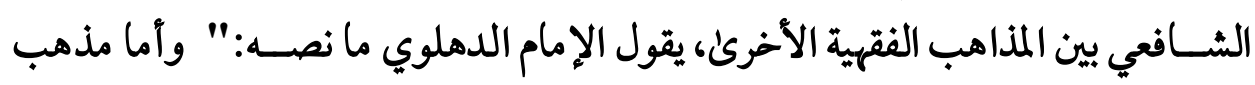

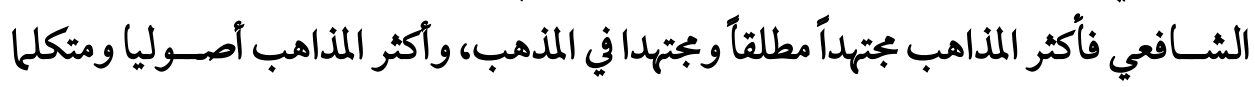

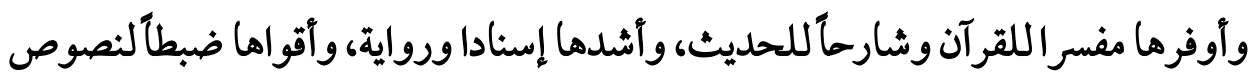

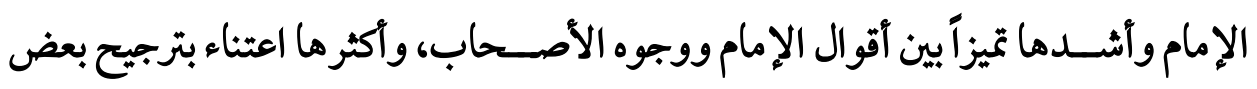

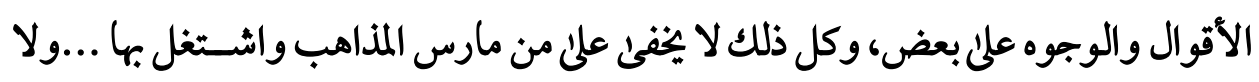

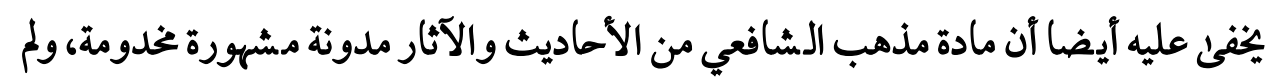

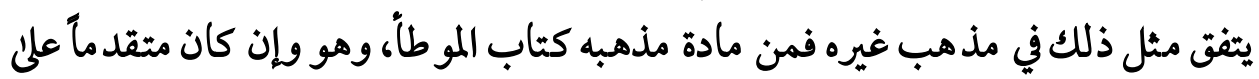

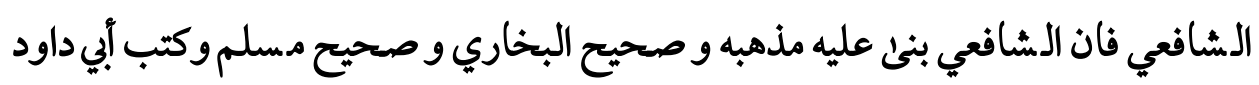

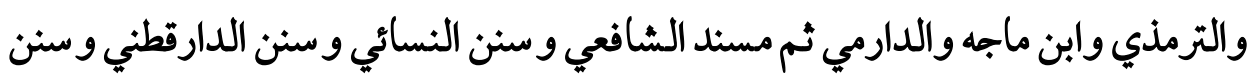

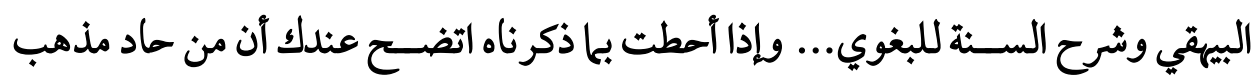

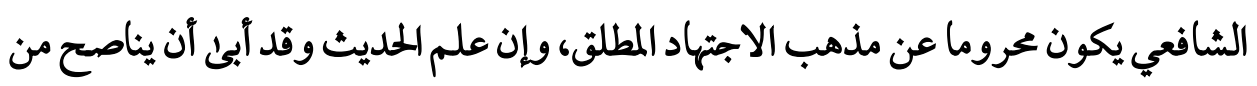

$$
\begin{aligned}
& \text { r. أ اهـ، تحقيق:صلاح الدين مقبول أهد، ص(VI). }
\end{aligned}
$$

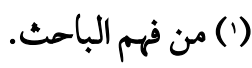


يتطفل على الشافعي وأصحابه رضي الله عنهم" (1).

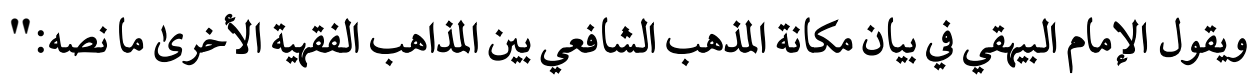

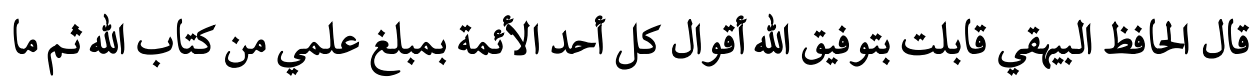

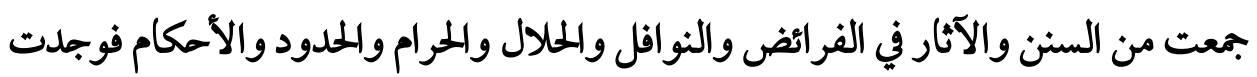

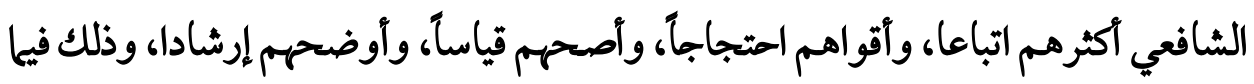

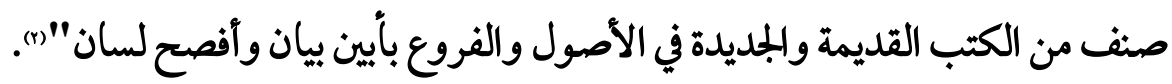

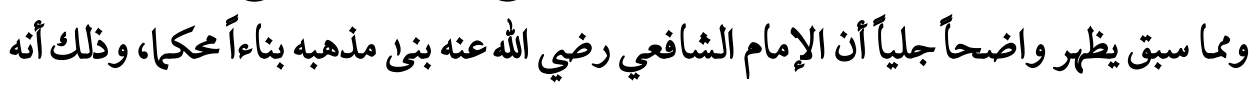

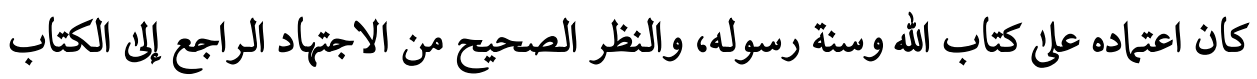

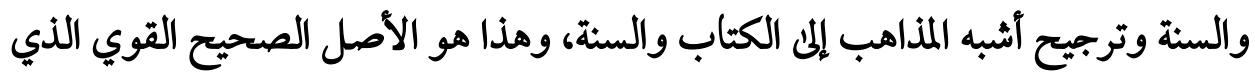

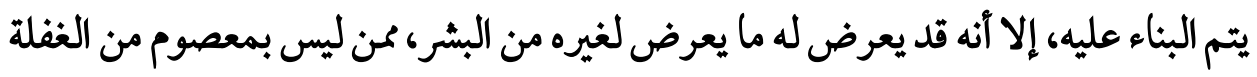

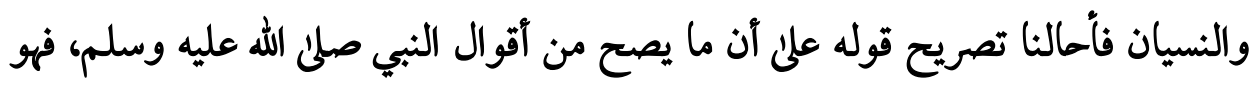

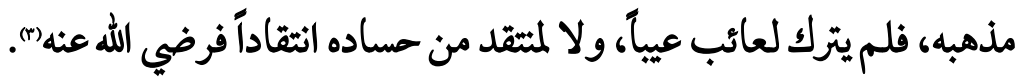

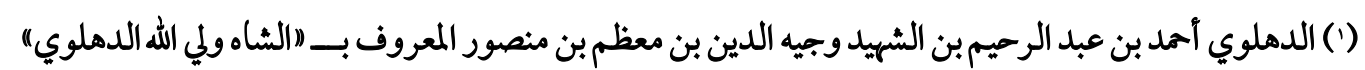

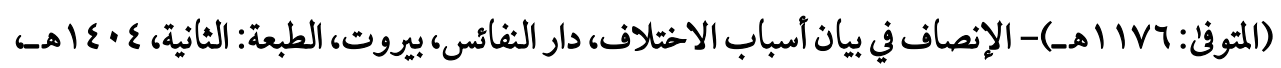

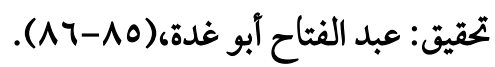

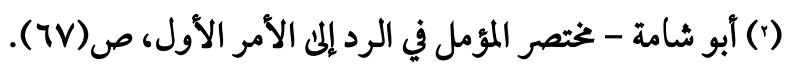

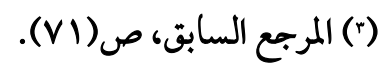




\section{المبحث الأول \\ ثماذج تطبيقية من الوسطية في قته العبادات}

لما كان الحكم علئ الشيء فرع عن تصوره، فإن معللجة هذا المبحث، سوف تشتمل علئ خمسة مطالب:

المطلب الأول: الوسطية في الطهارة.

المطلب الثاني: الوسطية في الوضوء.

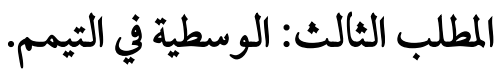

المطلب الرابع: الوسطية في صلاة الجمعة وخطبتها.

المطلب الخامس: الوسطية في زكاة الإبل.

\section{المطلب الأول}

\section{الوسطية في الطهارة}

لمل كان المكم علني الثيء فرع عن تصوره، فإن معلجة هذا المطلب سوف تشتمل على فرعين:

$$
\text { الفرع الأول: تعريف الطهارة لغة وشرعاً. }
$$

الفرع الثاني: الوسطية في المكم بطهارة الماء إذا اختلط به مائع يخالفه في الصفات.

$$
\text { الفرع الأول }
$$

تعريف الطهارة لغة وشرعاً

لما كانت الطهارة لها تعريفان أحدما في اللغة، والآخر في الشرع، فإن معالجة هذا الفرع الفرعاع

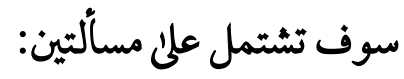

المسالة الأولم: تعريف الطهارة لغة.

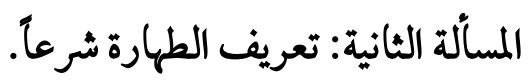

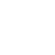




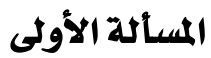 \\ تعريف الطهارة لغة}

الطهارة لغة: النظافة حسية آو معنوية").

\section{المسائل الثانية \\ تعريف الطهارة ثرعاً}

عرف فقهاء الشافعية الطهارة بأنها: ارتفاع المنع المترتب على المهارة فئل والنجس (r).

$$
\text { الفرع الثاني }
$$

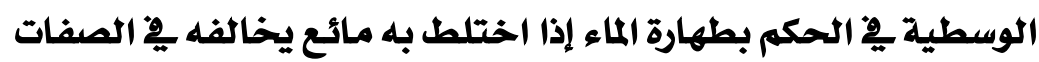

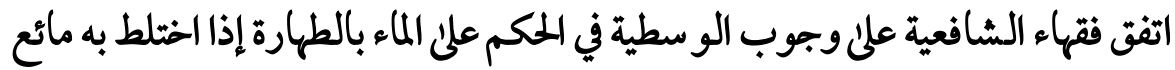
يخالفه في الصفات، فإذا اختلط بالماء ماتع طاهر واستهلك في الماء لقلته، وكثرة الملاء مع خخالفة

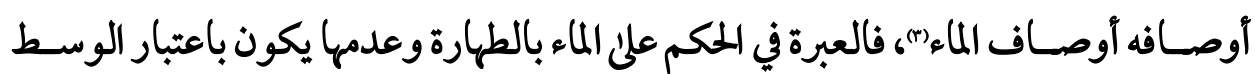

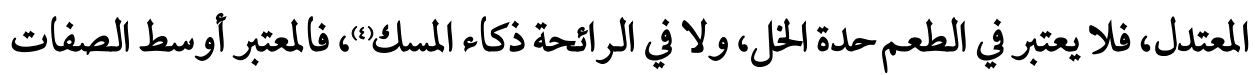

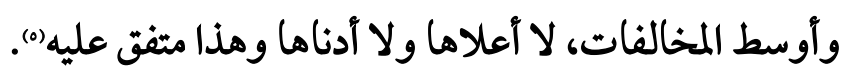

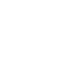

(') المناوي زين الدين محمد المدعو بعبد الرؤوف بن تاج العارفين بن علي بن زين العابدين الحدادي ثم المناوي

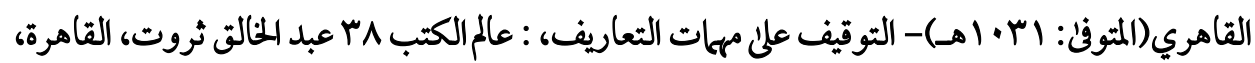

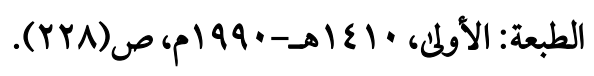

(') الخطيب الشربيني شمس الدين، محمد بن أمد الخطيب الشربيني الشافعي(المتوفن: 9VVهـ)- الإقناع في حل ألفاظ أبي شجاع، الناشر : دار الفكر، بيروت، تحقيق: مكتب البحوث والدراسات - دار الفكر، (1 / 1 ). (r) الخطيب الشربيني شمس الدين، محمد بن أمد الخطيب الشربيني الشافعي (المتوفن: 9VVهـ)- مغني المحتاج إلى دالى

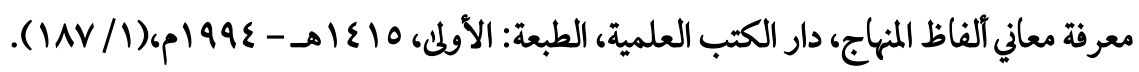
(") حيث جاء ما نصه:" إذا استهلك الخليط الطاهر في الماء، لقلته مع مخالفة أوصافه أوصاف الماء. قال الأصحاب: .... وفي الطاهر اعتبروا الوسط المعتدل، فلا يعتبر في الطعم حدة الخل، ولا في الرائحة ذكاء المسك " يراجع:

$$
\begin{aligned}
& \text { النووي - روضة الطالبين ، (1 / ). } \\
& \text { (·) النووي - المجموع شرح المذب،(1/ 1 + ). }
\end{aligned}
$$




\section{الأدلة:}

استدل فقهاء الشافعية على وجوب الوسطية في المكم بطهارة الماء إذا اختلط به مائع يخالفه في الصفات، بالكتاب الكريم، والسنة النبوية المطهرة ،والمعقول.

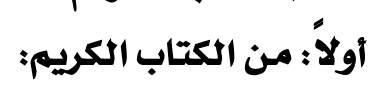

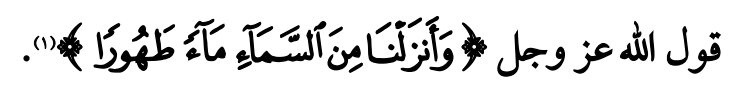
وجه الدلالة من الآية الكريمة:

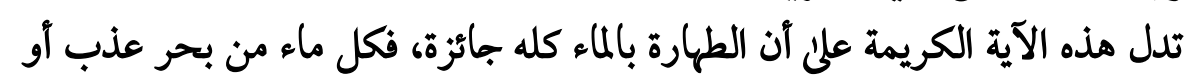

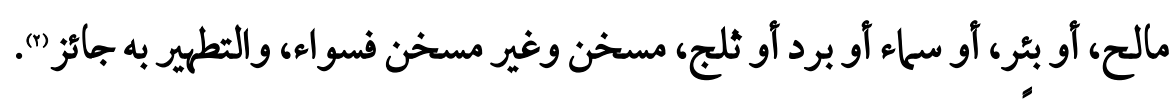

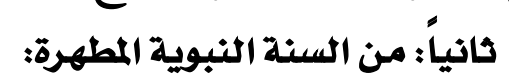

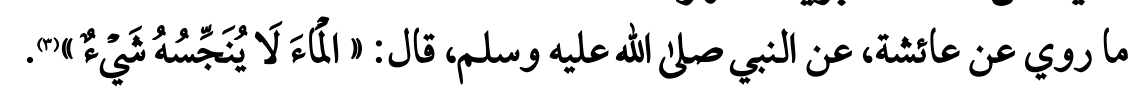
وجه الدلالة من الحديث الشريف:

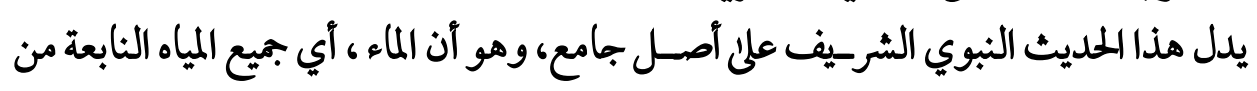

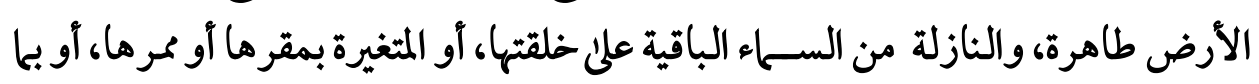

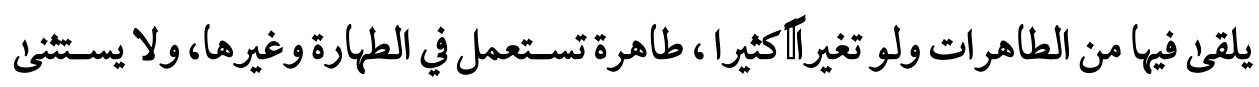

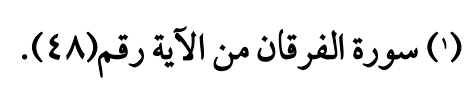

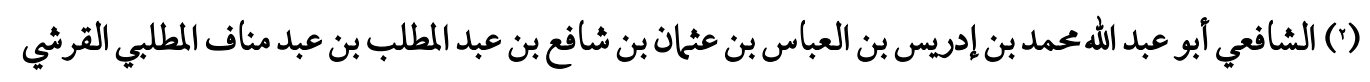

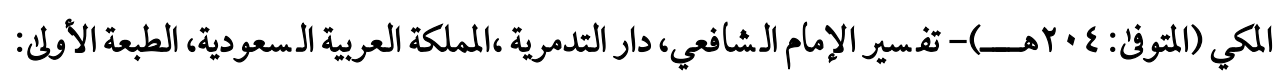

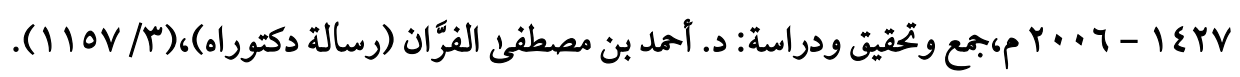

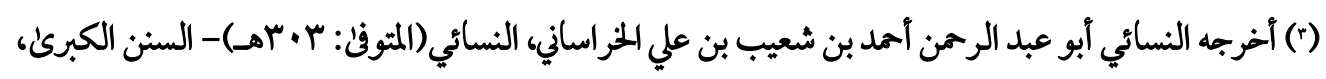

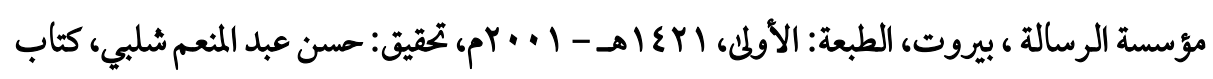

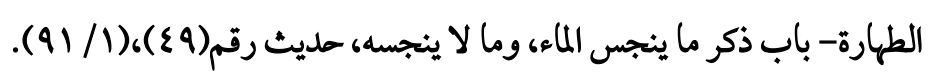

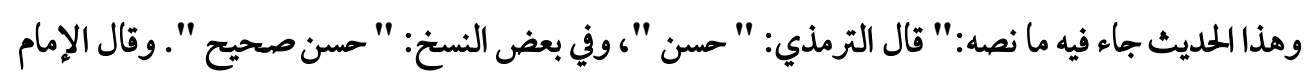

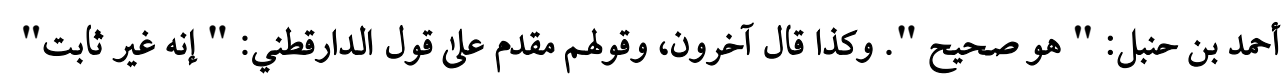

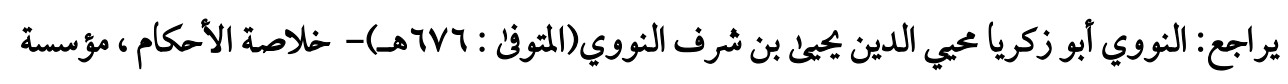

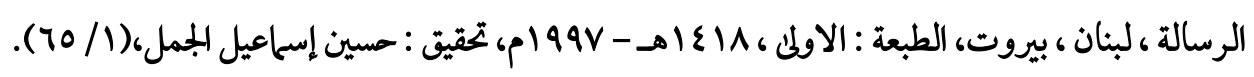


من هذا الكلام الجامع إلا الماء المتغير لونه أو طعمه أو ريحه بالنجاسة)".

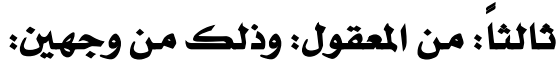

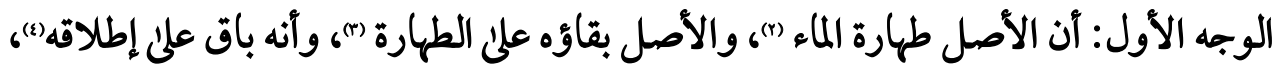

والماء المطلق طاهر مطهر غير مكروه"(م)، والقاعدة الفقهية تقول: الأصل بقاء ما كان علئ ما

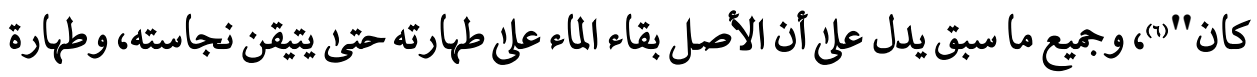

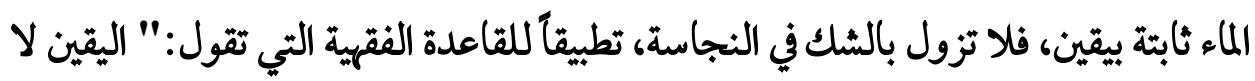

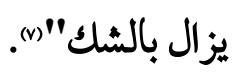

الوجه الثاني: أن الله تعالثي خلق الماء طهوراً، والأصل بقاؤه علئ خلقته (1).

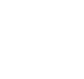

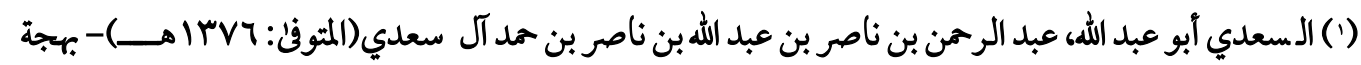

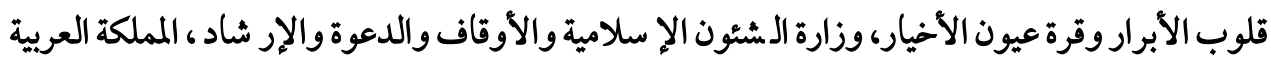

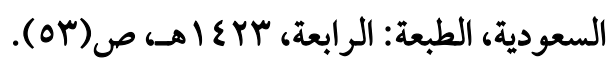

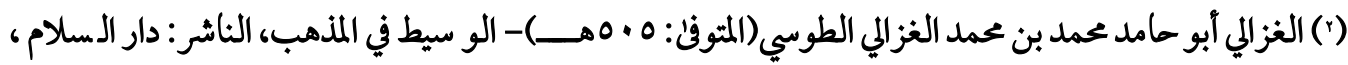

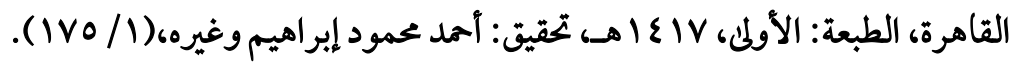

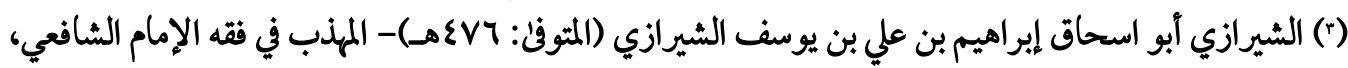

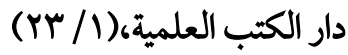

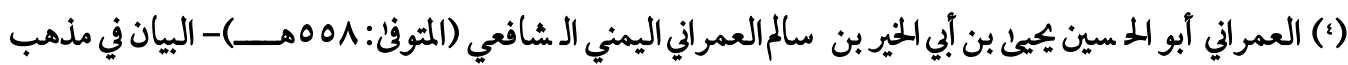

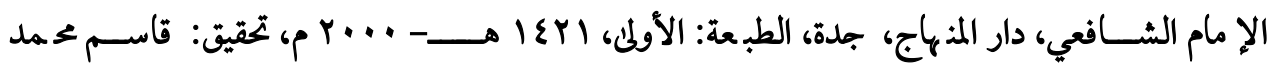

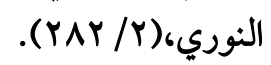

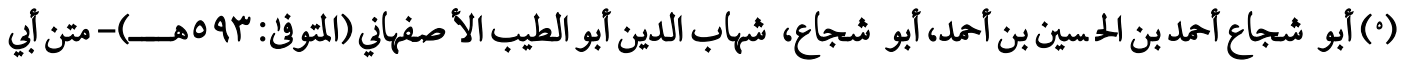

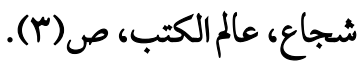

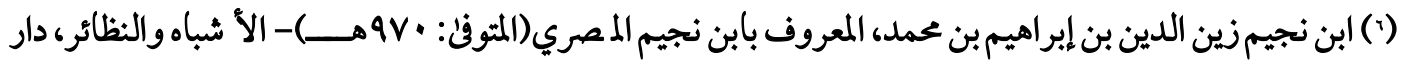

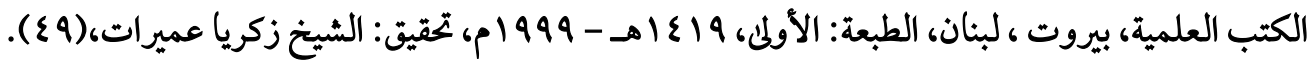

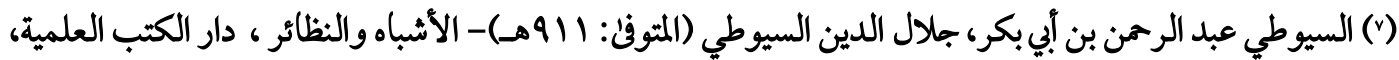

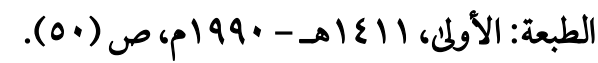
(^) العمراني - الييان في مذهب الإمام الشافعي، (1/ / م ه ). 


\title{
المطلب الثاني \\ الوسطيلة في الوضوية
}

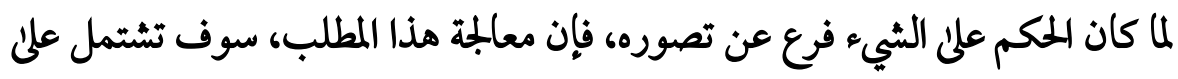

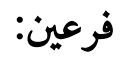

$$
\text { الفرع الأول: تعريف الوضوءلغة وشرعاً. }
$$

الفرع الثاني: الوسطية في الوضوء بين الإسراف والتقتير.

\section{الفرعالاول \\ تصريف الوضوء لفة وشرعاً}

لما كان الوضوء له تعريفان أحدهما في اللغة، والآخر في الشرع، فإن معالجة هذا الفرع، سوف تشتمل على مسألتين:

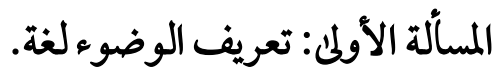

المسألة الثانية: تعريف الوضوء شرعاً.

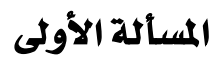 \\ تعريف الوضوء لغة \\ الوضوء لغة من الوضاءة وهو المسن والنظافة والنقاوة"). \\ المسالة الثانية \\ تعريف الوضوء شرعاً \\ عرف فقهاء الشافعية الوضوء بأنه: بضم الواو: اسم للفعل، وهو استعمال الماء في
}

(') القونوي قاسم بن عبد اللهبن أمير علي القونوي الرومي المنفي(المتوفن: 9VAهـ) - أنيس الفقهاء، دار الكتب العلمية،

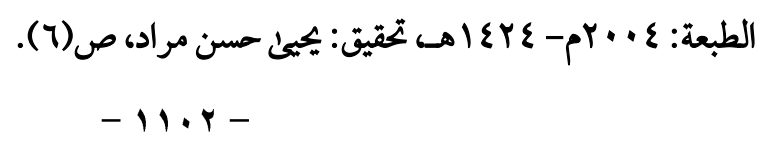


أعضاء يخصوصة وهو المراد هنا ويفتحها اسم للماء الذي يتوضاً به")

$$
\text { الفرع الثاني }
$$

الوسطية فِّ الوضوء بين الإسراف والتقتير

اتفق فقهاء الشافعية على استحباب الوسطية في الوضوء بين الإسراف والتقير (r).

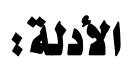

ا ستدل فقهاء المشافعية على ا ستحباب الو سطية في الو ضوء بين السرف والتقتير، بالكتاب الكريم، والسنة النبوية المطهرة والمعقول. أولاً: من الكتاب الكريه:

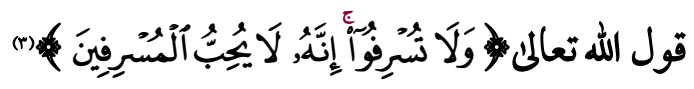

\section{وجه الدلالة من الآية الكريمة:}

تدل هذه الآية الكريمة على كراهية الإسراف والذي هو بجاوزة الحد المشرـوع في كل فعل آو قول بوجه عام، ومن ثم تشمل الإسراف في الوضوء وهو المطلوب إثباته()، فلحلاصل

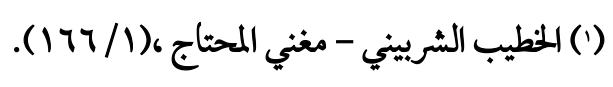

(') حيث جاء ما نصه:" وإن كان مقدار الماء كافياً لوضويء، صح الوضوء به، مع الاقتصاد في استعحال الماء" يراجع:

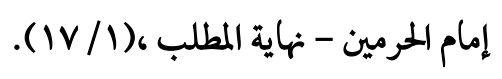

وجاء أيضاً ما نصه:" عبارة الخطيب ومنها أن يقتصد في الماء فيكره السرف فيه اهـ قال البجيرمي ويكره التقتير

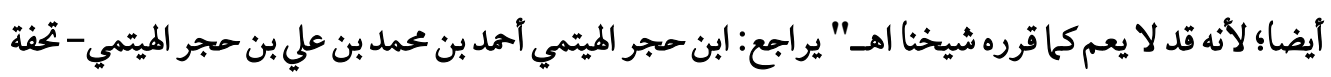

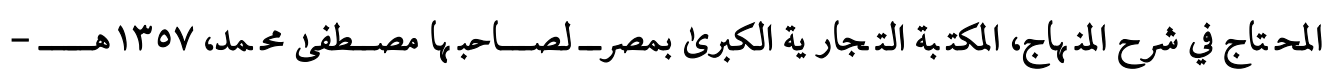

$$
\begin{aligned}
& \text {. ( } \varepsilon \varepsilon \cdot / 1) \text { (p) } 9 \wedge r \\
& \text { (r) سورة الأعراف من الآية رقم(1) }
\end{aligned}
$$

() ابن حجر العسقلاني أحمد بن علي بن حجر أبو الفضل العسقلاني الشافعي - فتح الباري شرح صحيح البخاري،

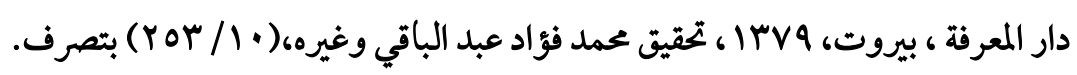


الأمــــور أن المذمومة شرعاًا).

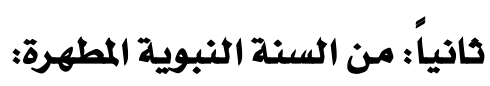
ما روي عن عبد اللهبن عمرو، أن رسول اللهصلئ الله عليه وسلم مر بسعد وهو يتوضاً،

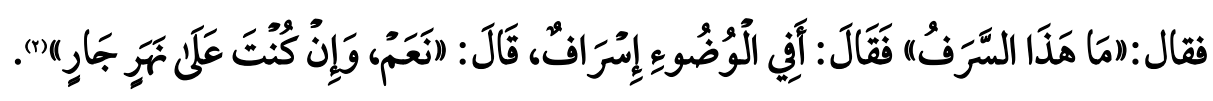
وجه الدلالة من الحديث الشريف: هذا الحديث الشريف يدل دلالة واضسحة علئ كراهية الإسراف في الوضسوء، إما فعلاً

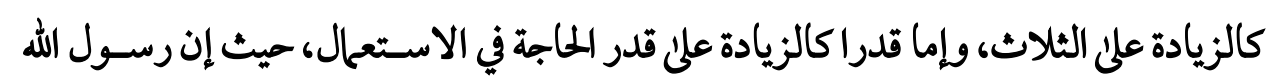

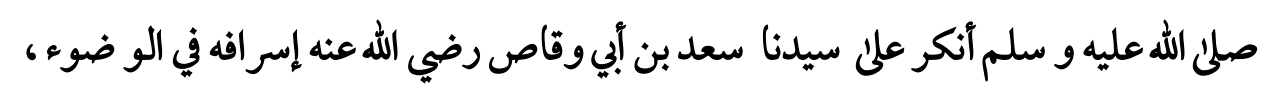

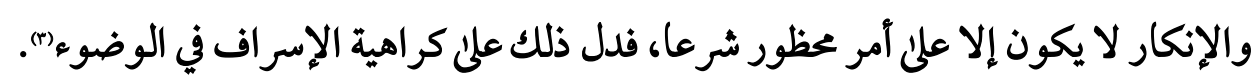

ثالثاً: من المعقول، وذلك من وجهين: الوجه الأول: أن الإسراف في الوضوء ودئرتب عليه إهدار الوقت وتضييع العمر، وتجاوزاًعن

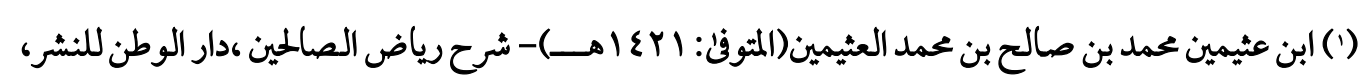

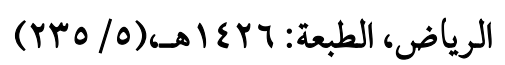

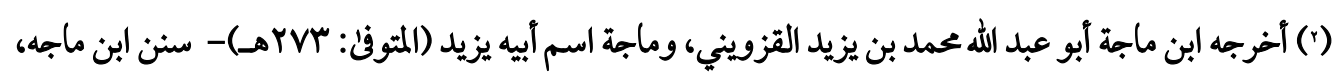

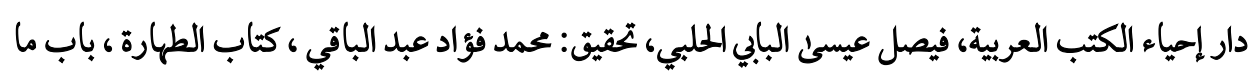

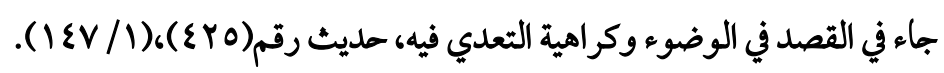

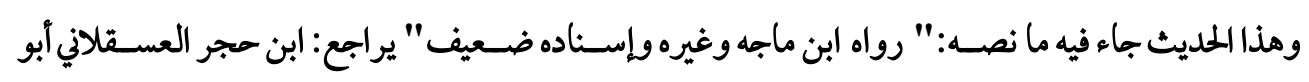

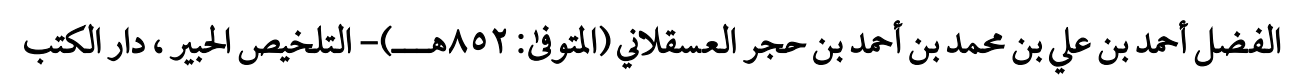

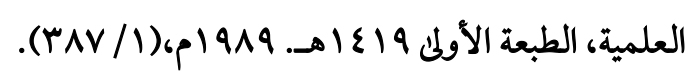

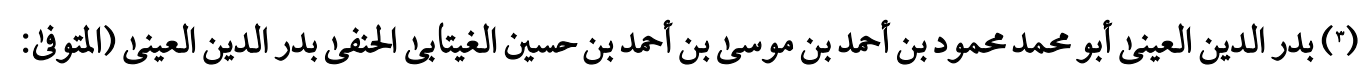

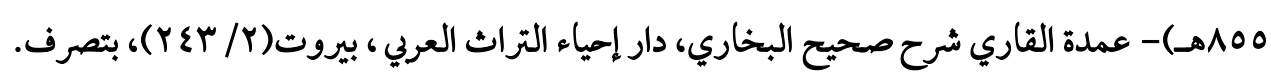


الحد الشرعي، والتقتير في الوضوء يترتب عليه الإخلال بالعبادة وهي أمور كرهها الإسلام

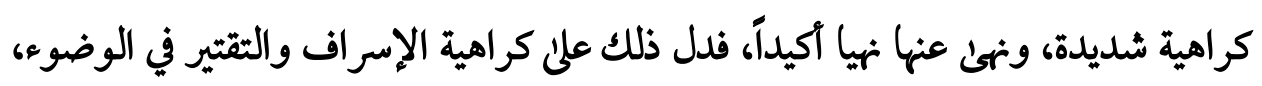
واستحباب التوسط فيه (1)

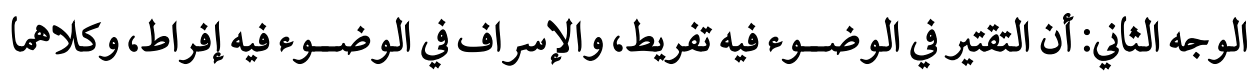

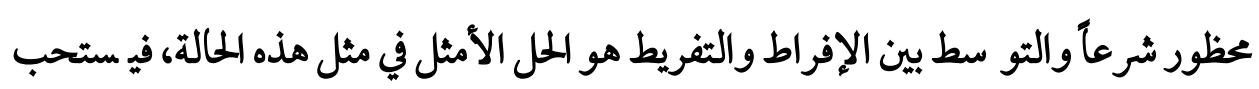
التوسط في الوضوء تجنباً للوقوع في الإثم").

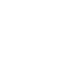

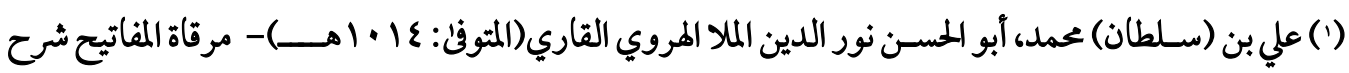

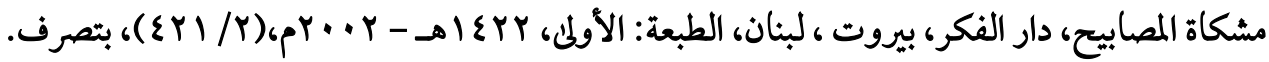




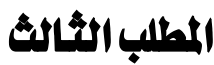

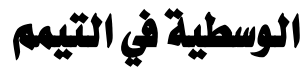

لما كان اللمكم على الثيء فرع عن تصوره، فإن معالجة هذا المطلب، سوف تشتمل على فرعين:

$$
\text { الفرع الأول: تعريف التيمم لغة وشرعاً }
$$

الفرع الثاني: الوسطية في طلب المسافر الماء قبل التيمم

الفرع الأول

\section{تعريف التيمم لغة وشرعاً}

لما كان التيمم له تعريفان أحدهما في اللغة، والآخر في الشرع، فإن معالجة هذا الفرع سوف تشتمل علما مسألتين:

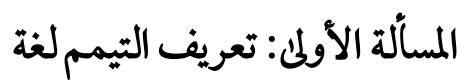
المسألة الثانية: تعريف التيمم شرعاً

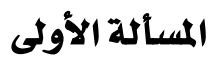

تعريف التيمم لغة

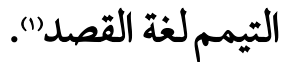

\section{المسالة الثانية \\ تعريف التيمي ثرعاً}

عرف فقهاء الشافعية التيمم شرعا بأنه: عبارة عن إيصال التراب إلى الوجه واليدين

بشر ائط خخصوصة(r).

(1) القاضي عبد الني بن عبد الرسول الأمدنكري(المتوفن: ق Y (هـ) - دستور العلماء، دار الكتب العلمية ، لبنان، بيروت، الطبعة:

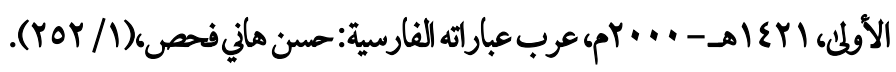

(') الحصني أبو بكر بن محمد بن عبد المؤمن بن حريز بن معلن الحسيني الحصني، تقي الدين الشافعي (المتوفن:

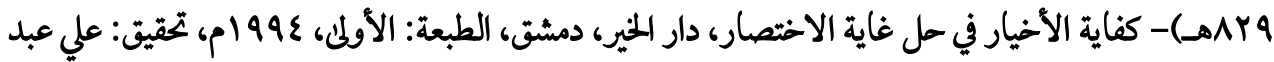

$$
\text { اللحميد بلطجي وغيره، ص(ه) }
$$




\section{الثرعالثاني \\ الوسطيلة في طلب المساضز الماه قبل التيبم}

اتفق فقهاء الشافعية علئ وجوب طلب المسافر الماء قبل التيمـ"(1)، مع مراعاة حد القرب وهو ما يصله المسافر لحاجته بسهولة ويسر، ومع اعتبار الوسط المعتدل بالنسبة إلى الوعورة والسهولة والصيف والشتاء، فإذا كان الأمر كذلك وجب عليه طلب الماء قبل التيمم بشرط أن لا يخاف ضرراً في نفسه، أو ماله أو انقطاعه عن رفقته آو خروج الوقت، فإن خاف ما ذكر أو كان الماء في مكان بعيد، وهو ما يسمى حد البعد وهو ما يصله المسافر بشق الأنفس وييد في الوصول إليه مشقة وعناء، فلا يجب عليه في هذه الحلالات طلب الماء لما فيه من المشقة والضرر وييوز له التيمم (r)

\section{וالأدلة:}

أولاً: أدلة وجوب الوسطية في طلب المسافر الماء قبل التيمم:

ا ستدل فقهاء المشافعية على وجوب الو سطية في طلب المسافر الماء قبل التيمم، بالكتاب

(') حيث جاء ما نصه:" وليس للمسافر آن يتيمم إلا بعد دخول وقت الصلاة وإعواز الماء بعد طلبه" يراجع:

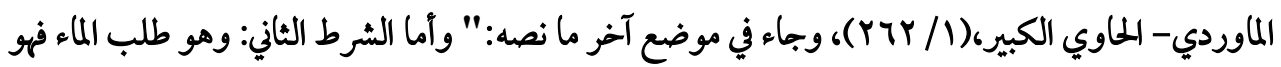

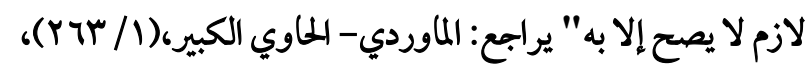

(r) حيث جاء ما نصه:" (فلو علم) مسافر بمحل (ماء) في حد القرب وهو ما (يصله المسافر لحاجته) كاحتطاب واحتشاش مع اعتبار الوسط المعتدل بالنسبة إلى الوعورة والسهولة والصيف والشتاء وهذا فوق حد الغوث الذي يقصده عند التوهم قال محمد بن يجيخ: لعله يقرب من نصف فرسخ (وجب قصده) أي طلبه منه؛ لأنه

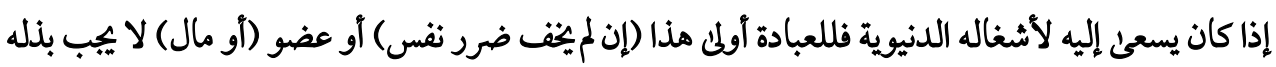

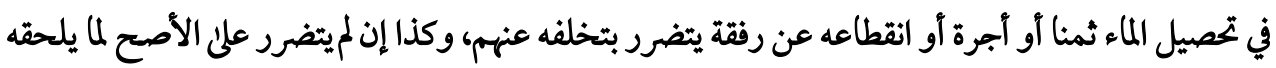
من الوحشة أو خروج الوقت (فإن) خاف ما ذكر أو (كان) الماء بمحل (فوق ذلك) المحل المتقدم، وهذا يسمى لئل حد البعد (تيمم) ولا يحب عليه الطلب لما فيه من المشقة والضرر" يراجع: الخطيب الشريني - مغني المحتاج، 
الكريم، والسنة النبوية المطهرة والمعقول.

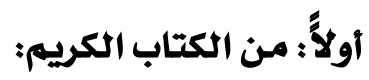

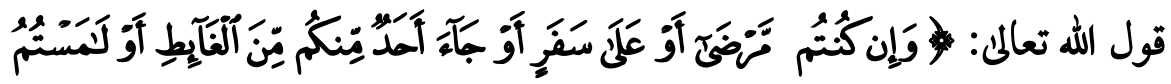

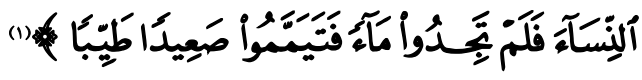

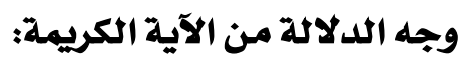
في هذه الآية الكريمة أباح الله عز وجل التيمم بعد الوجودة، والوجود هو الطلب؛ لأن اللسان يقتضيه وعرف الخطاب يوجبه ألا ترئ لو أن رجلا قال لعبده اشتر لحما فإن لم تجد

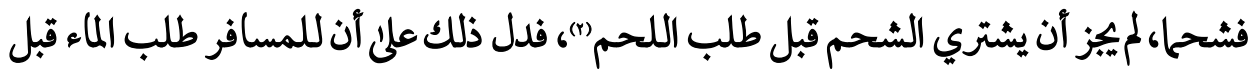

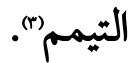

\section{كانيا: من السنة النبوية المطهرة:}

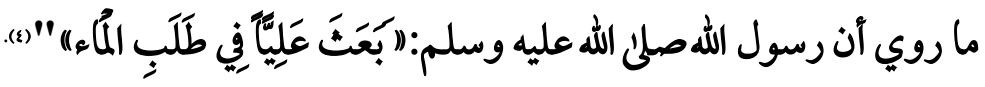
وجه الدلالة من الحديث الشريف:

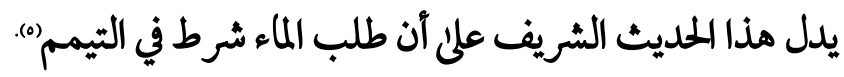

$$
\begin{aligned}
& \text { (1) سورة المائدة من الآية رقم(7). }
\end{aligned}
$$

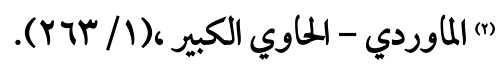

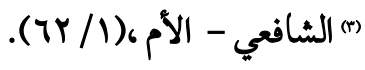

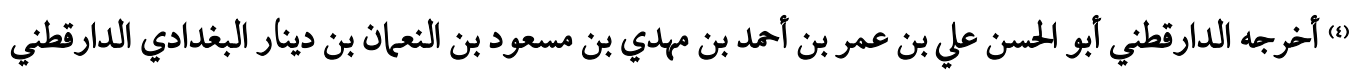

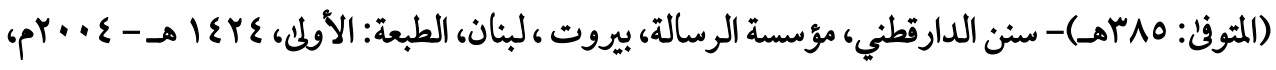

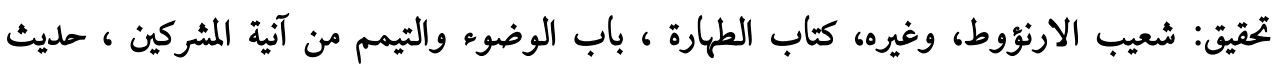

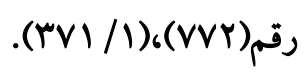

وهذا الحديث جاء فيه ما نصه:" رواه ابن ماجه وغيره وإسناده ضعيف" يرابع: ابن حجر العسقلاني -

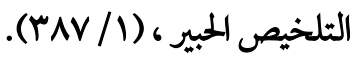

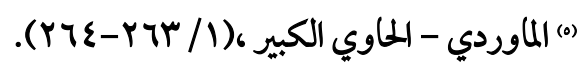




\section{ثالثاً: من المعقول: وذلك من أربعة وجوه:}

الوجه الأول: أن كل موضع لو تيقن وجود الماء فيه، منع التيمم وجب إذا جوز وجود الماء فيه أن لا يجوز له التيمم قياساً على رحله (1). الوجه الثاني: أن كل بدل لا يصح الإتيان به إلا بعد طلب العجز عن مبدله لميصح الإتيان به إلا بعد طلب مبدله، كالصوم في الكفارة ، لا يجوز إلا بعد طلب الرقبة (r). الوجه الثالث: أن التيمم مع وجود القدرة على الملاء لاييوز (r).

الوجه الرابع: أن الأصل في الطهارة هو الوضوء والتيمم بدل عنه ولا يتتقل إلى البدل إلا بعد العجز عن الأصل الذي هو الوضوء فوجب طلب الماء ،لأن ما لا يتأدي الواجب إلا به فهو واجب)

ثانياً: أدلة عدم وجوب طلب المسافر الماء قبل التيميم يِ حالة الخوف على النفس، أو المال، وغير ذلك.

استدل فقهاء الشافعية علئ عدم وجوب طلب المسافر الماء قبل التيمم في حالة الخوف علن النفس، آو المال، وغير ذلك، بالكتاب الكريم، والسنة النبوية المطهرة ،والمعقول. أولأ: من الكتاب الكريه:

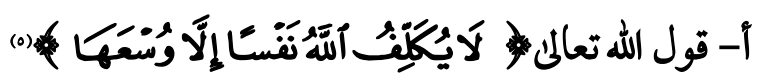

$$
\begin{aligned}
& \text { (') المرجع السابق ، (1) (1) (1) ) } \\
& \text { (r) (1)، الماوردي - اللحاوي الكبير (r) (1) } \\
& \text { (r) (المرجع السابق ، (1) (1)، بتصرف. (1) }
\end{aligned}
$$

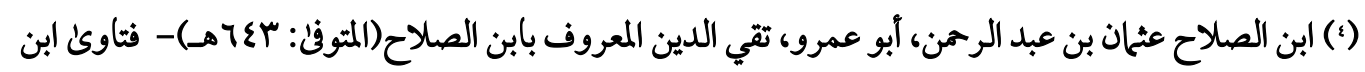

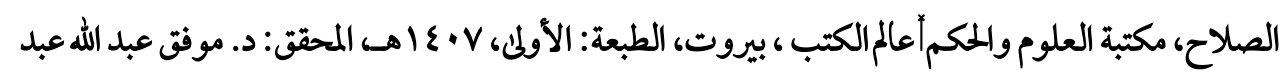

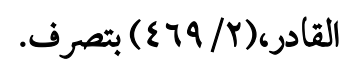

$$
\begin{aligned}
& \text { (•) سورة البقرة من الآية رقم(Y^)). }
\end{aligned}
$$


وجه الدلالة من الآية الكريمة:

تدل الآية الكريمة على آن التكليف يكون بحسب الطاقة وفي تكليف المسافر بطلب الماء قبل التيمم مع خوفه علنى نفسه، أو ماله، أو غير ذلك ، فيه تكليف ما لا يطاق، وهو ممنوع شرعاً بصريح الآية الكريمة').

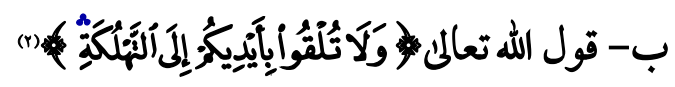
وجه الدلالة من الآية الكريمة:

في هذه الآية الكريمة ينهن الله عز وجل عن إلقاء النفس في التهلكة وفي تكليف المسافر بطلب الماء قبل التيمم مع خوفه على نفسه، أو ماله، أو غير ذلك، يعتبر من إلقاء النفس في التهلكة، وهو محرم شرعاً بنص الآية الكريمة"(r). ثانياً: من السنة النبوية المطهرة:

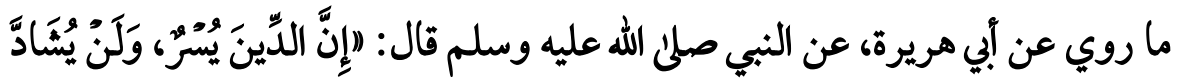

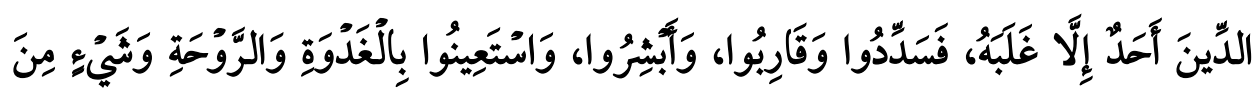

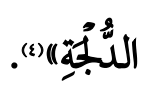

(') مقاتل بن سليان أبو المسن مقاتل بن سليان بن بشير الأزدي البلخحي (المثوفى: • 0 (هـ) - تفسير مقاتل بن سليان، دار إحياء

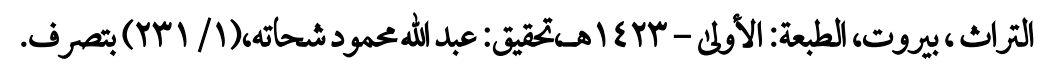

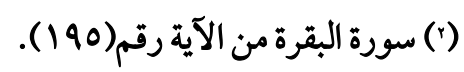

(r) القرطبي أبو عبد الله محمد بن أمد بن أبي بكر بن فرح الأنصاري المزرجي شمس الدين القرطبي (المتوفى : 17V) : أحمد البردوني وغيره، (r/ rآr) بتصرف.

(؛) أخرجه البخاري محمد بن إسماعيل أبو عبدالله البخاري الجعفي- صحيح البخاري، الناشر: دار طوق النجاة

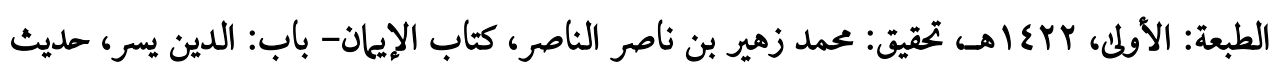

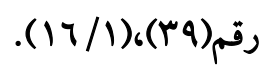


وجه اللهلالة من الحليث الشيريف:

يدل هذا الحديث النبوي الششريف على و سطية الإ سلام و سحاحته، كما يدل على تحريم

التشديد في الدين بأن يحمل الإذسان نفسه من العبادة مالا يحتمله، إلا بكلفة شديدة، فدل ذلك على عدم وجوب طلب المســافر الماء قبل التيمم في حالة الخوف علنى النفس، أو الملال،

وغير ذلك، لأن في إيباب ذلك مشقة شديدة لا تحتمل (1). ثالثاً: من المعقول: وذلك من أربعة وجوه:

الوجه الأول: أن تكليف المســافر طلب الماء مع خوفه على نفسـهـ أو ماله، آو غير ذلك فيه إلحاق ضرر كبير به، والقاعدة الفقهية تقول:" الضرر يزال "(r)

الوجه الثاني: : أن تكليف المســافر طلب الملاء مع خوفه على نفسـهـ أو ماله، أو غير ذلك فيه تعارضت مصلحة ومفسدة، أما المصلحة فهي تتمثل في وجوب طلب الماء لأداء العبادة تقرباً إلى الله عز وجل، وأما المفســدة فهي هلاك النفس أو الملال أو هما معاً، والقاعدة الفقهية تقول "درء المفا سد أوله من جلب المصالح" فإذا تعار ضت مفسدة ومصلحة قدم دفع المفسدة غالباً؛ لأن اعتناء الشرع بالمنهيات أشد من اعتنائه بالمأمورات(r). الوجه الثالث : أن تكليف الممسـافر طلب الماء مع خوفه على نفسـهـ أو ماله آو غير ذلك فيه إلحاق مشقة كبيرة به فوق مشقة السففر، وهو أمر لا تحتمله النفس، والقاعدة الفقهية تقول:

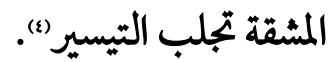

(') ابن رجب زين الدين عبد الرحمن بن أحمد بن رجب بن الحسن، السَلامي، البغدادي، ثم الدمشقي، الحنبلي (المتوفن:

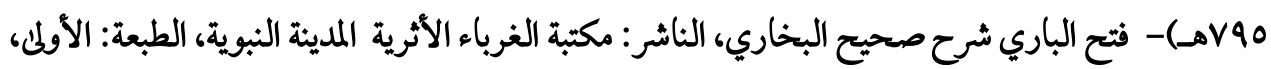

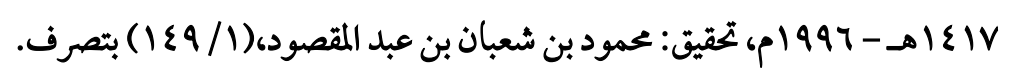

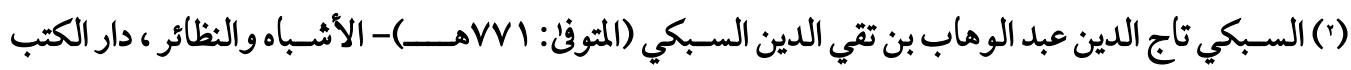

$$
\begin{aligned}
& \text { العلمية، الطبعة: الأولى ل| (ع (هـ- (99 امو(1/ (ع). }
\end{aligned}
$$

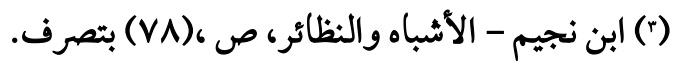

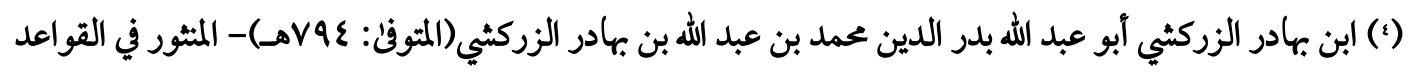


الوجه الرابع: أن طلب المســافر الماء قبل التيمم حق من حقوق الله عز وجل وحقوق اللهز وجل مبنية على المساعحة بخلاف حقوق الآدمي".

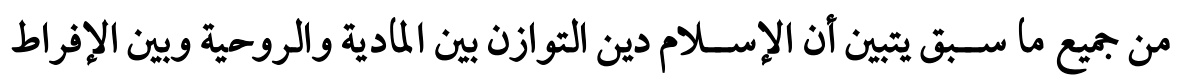
والتفريط؛ لا يطغن أحدهما على الآخر، بل تو سط بين المادية والروحية، وجمع بينها في توازن

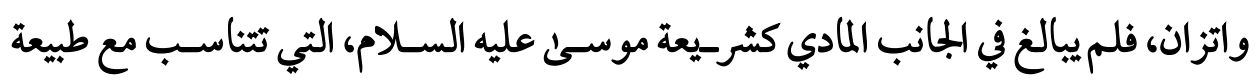

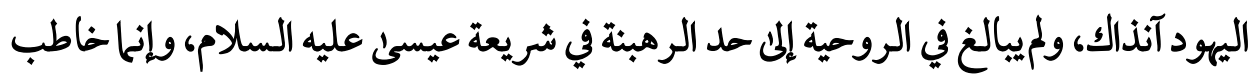
العقل والقلب معا بعد اكتماله بشر-يعة الإسـلام، فلا تقبل المبالغة فيها؛ فحث علئ العمل والكسـب وجمع المادة، وجعلها عبادة روحية، ما دامت ابتغاء مرضـاة الله تعالمى، لذلك كانت

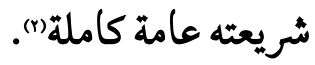

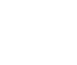

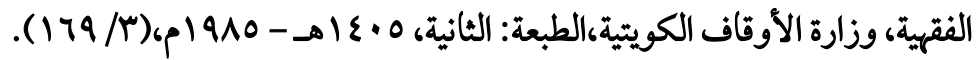

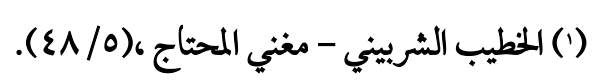

(1) الدكتور علي علي صبح- التصوير النبوي للقيم النلقية والتشريعية في المديث الشريف، المكتبة الأزهرية للتراث،

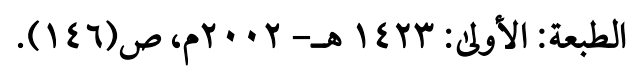




\section{المطالب الزابع

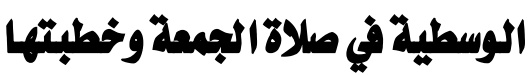 \\ الوسطية في صلاة الجمعة وخطبتها).}

اتفق فقهاء الشــافعية على وجوب صــلاة الجمعة وخطبته)(1)،كل) اتفقوا على اسـتحباب

الأدلة:

أ- أدلة وجوب صلاة الجمعة وخطبتها:

ا ستدل فقهاء الـشافعية علئ وجوب صلاة الجمعة وخطبتها، بالكتاب الكريم، والـسنة

النبوية المطهرة، والإجماع، والمعقول.

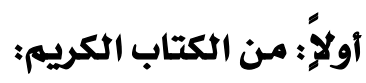

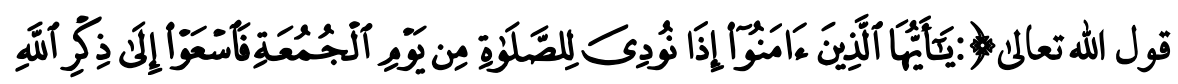

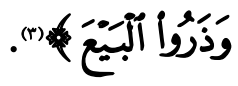

\section{وجه الدلالة من الآية الكريمة:}

تدل هذه الآية الكريمة على وجوب صلاة الجمعة وخطبتها، حيث إن المراد بذكر الله فيها

هو الصلاة، واللطبة جميعاً، لاشتمالما على ذكر الله).

ثانياً: من السنة النبوية المطهرة:

ما روي عن عبد الله بن مسعود آن النبي صلنى الله عليه وسلم قال لقوم يتخلفون عن انب

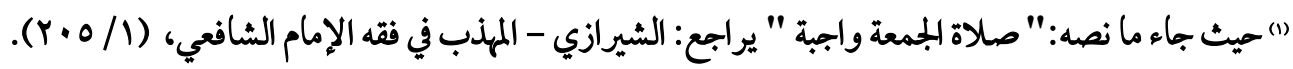

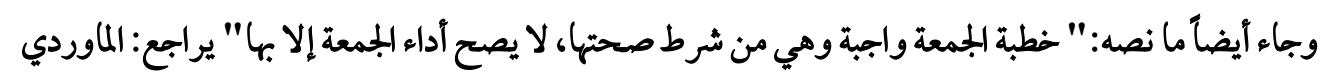

$$
\text { - الحاوي الكبير (r/ ( }
$$

(") حيث جاء ما نصه " المحبوب فيها التوسط " يراجع: الرافعي - فتح العزيز،(ع/ ( + 7).

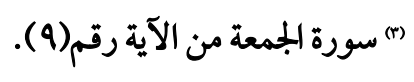

(2) الصابوني محمد علي الصابوني - روائع البيان تفسير آيات الأحكام، مكتبة الغزالي ، دمشق، مؤسسة مناهل العرفان،

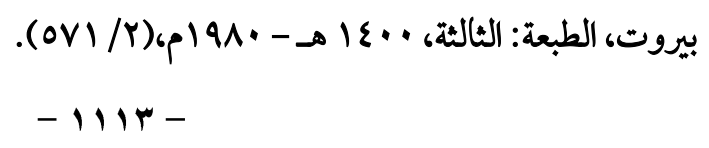




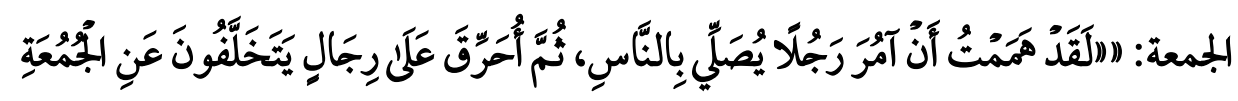

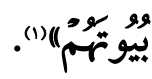

\section{وجه الدلالة من الحديث الشريف:}

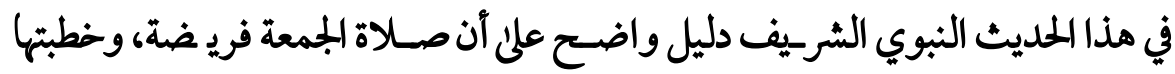
كذلك، لأن لهـلاة الجمعة لا تجوز بدون خطبة، وما لا يتم الواجب إلا به يكون واجباً مثله، ومما يوكد هذا الوجوب أن رسـول اللهصـلن الله عليه وسـلم توعد من يتخلف عن صــلاة الجمعة وخطبتها بحرق بيته، ولا يكون هذا الوعيد الشديد إلا لأمر واجب(").

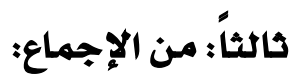
أجمع المسلمون علئ وجوب الجمبعة وخطبتها".).

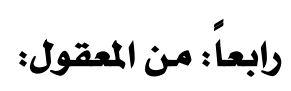

أن صلاة الجمعة وخطبتها بمثابة الثيء الواحد، لا وجود لأحدما بدون الآخر، فدل ذلك على وجوب صلاة الجمعة وخطبتهان.

ب- أدلة استحباب الوسطية فِ صلاة الجمعة وخطبتها. استدل فقهاء الشافعية علئ استحباب الوسطية في صلاة الجمعة وخطبتها، بالسنة النبوية

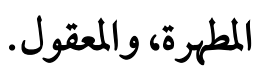

(1) أخرجه مسلم بن الحجاج أبو المسن القشيري النيسابوري(المتوفن: (آبهــ) - صحيح مسلمه، دار إحياء التراث

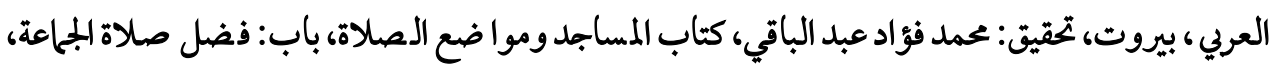

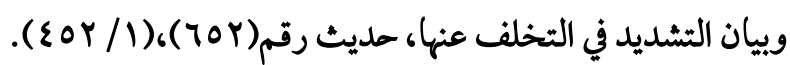

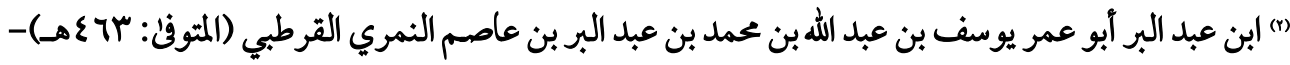

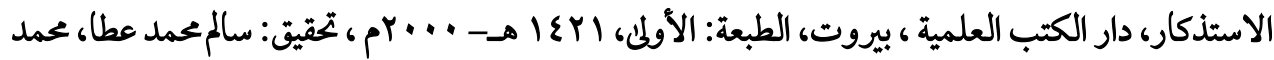

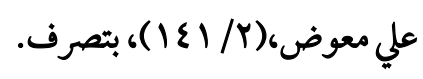

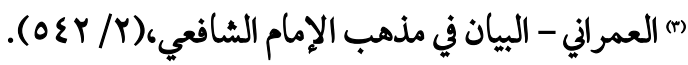

$$
\text { (1) من فهم الباحث. }
$$


أولاً: من السنة النبوية المطهرة:

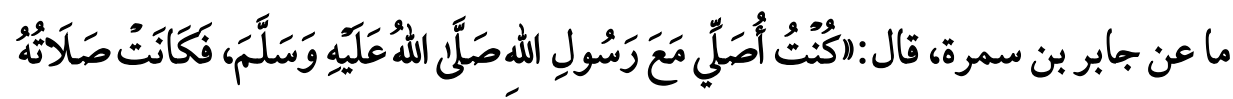

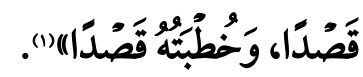

وجه الدلالة من الحلديث الشريف:

يدل مذا الحديث النبوي الشريف علنى استحباب الوسطية في صلاة الجمعة وخطبتها، حيث إن كلمة قصداً في الحديث الشريف معناها التوسط بين الطول والقصر، والمعنى آن صلاته عليه الصلاة والسلام كانت: متوسطة بين الإفراط والتفريط، من التقصير والتطويل، وخطبته

كذلك (1).

ثانياً: من المعقول: وذلك من وجهين:

الوجه الأول: أن التوسط في صلاة الجممعة وخطبتها فيه تيسير على الناس ورفق بهم؛ وفيه أيضاً أداء العبادة على وجهها المشروع من غير زيادة ولا نقصان، وهو مطلب شرعي أصيل (r). الوجه الثاني: أن تطويل صلاة البممعة وخطبتها عن الحد الوسط المعتلل يجعل الناس يملون من العبادة، وتقصير هما عن الحد الوسط المعتلل يخل بمقصود العبادة وكلاهما منوع شرعاً (8).

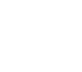

(1) أخرجه مسلم - صحيح مسلم، كتاب: الصلاة، باب: تخفيف الصلاة والخطبة، حديث رقم(177)،(Y / (1) (1).

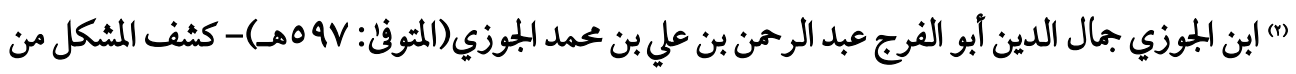

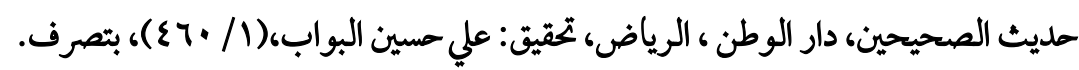
(r) (8) الشوكاني محمد بن علي بن محمد بن عبد الله الشوكاني اليمني (المتوفن: ـ Y (هـ) - نيل الأوطار، دار الحديث،

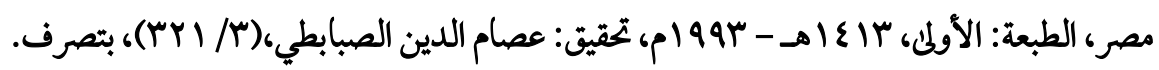




\section{المhاب الأحامس}

\section{الوسبطية في زكاةالإبل}

اتفق فقهاء الشافعية على أن آول نصاب الإبل خمس ويجب فيها شاة (1). الأدلة:

استدل فتهاء الشافعية على أن أول نصاب الإبل خمس ويجب فيها شاة ، بالسنة النبوية المطهرة، والمعقول.

\section{أولاً: من السنة النبوية المطهرة:}

ما روي عن أنس بن مالك رضي الله عنه آن آبا بكر رضي الله عنه، كتب له كتاباً لما وجهه إلى

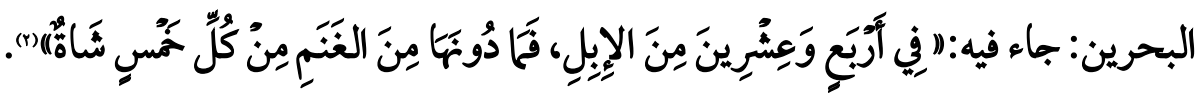

وجه الدلالة من الحديث الشريف:

يدل هذا للحديث النبوي الشريف على ابتداء نصاب الإبل وقدر الواجب فيه فأول نصاب الإبل

خمس، يجب فيها شاة، كا يلل أيضاً على أنه لا يجب في أربع وعشرين من الإبل إلا الغنم (Y). ثانياً: من المعقول: وذلك من ثلاثة وجوه:

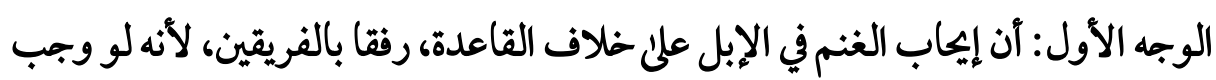
بعير لأضر بأرباب الأموال، ولو وجب جزء بعير، لأضر بالفريقين بالتشقيص (8)،

(') حيث جاء ما نصه:" لا اختلاف بين العلماء أن أول النصاب في الإبل خمس، وأن الواجب فيها شاة "يراجع: الماوردي-

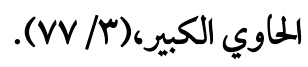

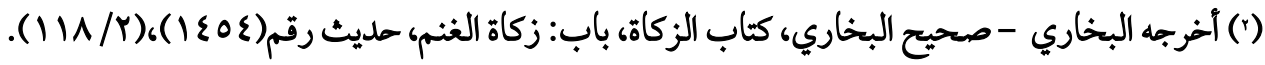

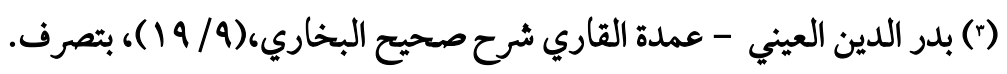

$$
\text { (؛) الرملي - نهاية المحتاج ،(س/ م ع ). }
$$


والتشقيص (1)، على كل قول في الحيوان بجتبب(r).

الو جه الثاني: أن ايياب الشـاة في الإبل على خلاف الأصـل، لأنها من غير الجنس، لكن في مشرسوعية ذلك رفق بالجانبين، إذ إخراج بعير في خمسـة أبعرة فيه إجحاف بالمالك، وفي عدم

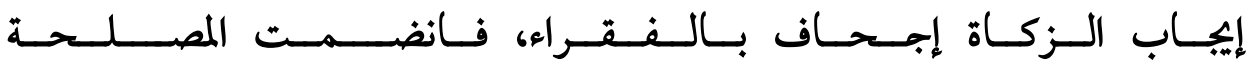
لهما بالشاة (r). الوجه الثالث: أن الإبل قد بلغ دون الخمس والعشرين مبلغاً يحتمل المواساة، ولمير الثارع آن يوجب فيها دون الخمس والعشرين بعيراً، فيكون إجحافاً برب المال، ولمير آن يوجب شقصاً من بعير؛ لما في التشقيص من التعذر، ونقصان القيمة؛ فعدل عن جنس الإبل إلى الغنم، فأوجب في خمس شاة، وفي عشرين أربع شياه(8). وهنا تظهر وسطية الإسلام وعدالته في مراعاة مصلحة الفريقين، ودفع الضرر عنها، فلم يجامل الإسلام آحد الفريقين على حساب الآخر، ولكنه وضع في اعتباره المصلحتين معاً.

(') التشقيص: التجزية، والشقص الجزء من الشيء: يراجع: المطرزئ ناصر بن عبد السيد أبيل المكارم ابن علنها أبو

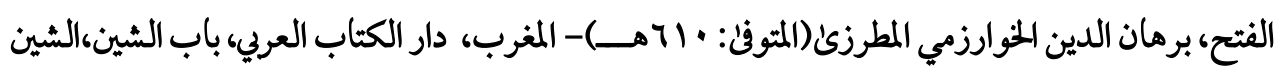

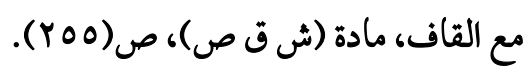

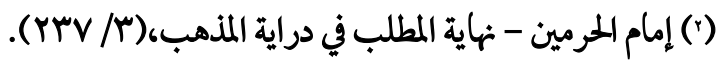

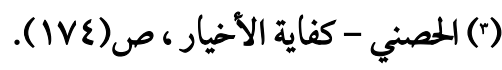

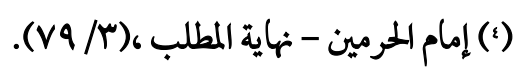




\section{المبحثة الثاني \\ نعاذج تطبيقية من الوسطية في قثه المعاملات}

توطئة: - ( )

إن فقه المعاملات الشرعية والذي مصدره الشريعة الإ سلامية، هو بلا شك أفضل

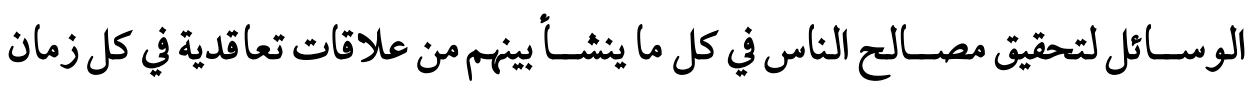

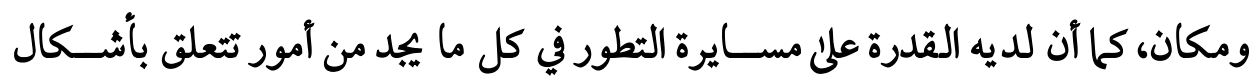

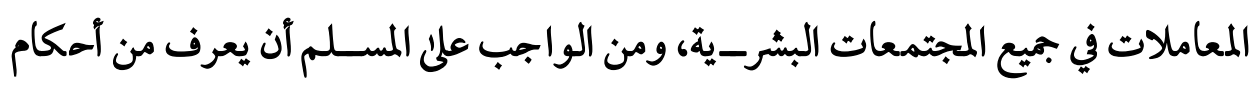

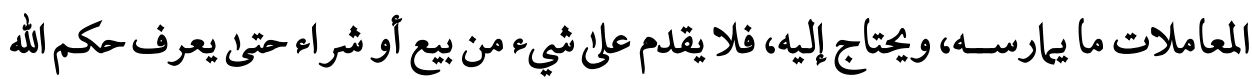

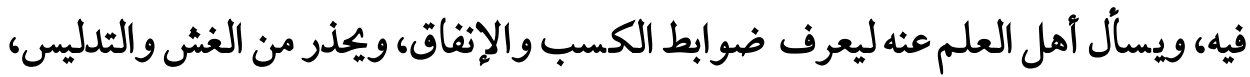
وأخذ أموال الناس بالباطل، ويجذر من الإسراف والتبذير، والبخل والتقتير، حتى تكون تصرفاته، في ضوء الكتاب والسنة. ولما كان الحكم علئ الثيء فرع عن تصوره، فإن معلجة هذا المبحث سوف تشتمل علئ

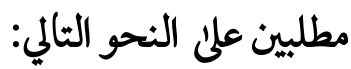

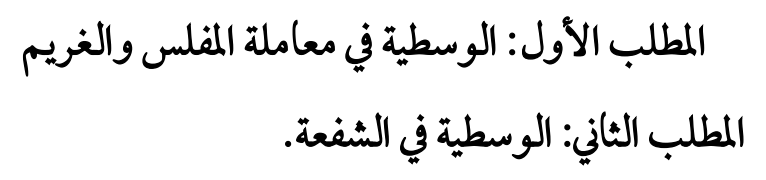




\section{المطلب الأول \\ الوسطية يِّ معاملة المفلس والغريم}

لما كان الحكم على الثيء فرع عن تصوره، فإن معللجة هذا المطلب سوف تشتمل على فرعين: الفرع الأول: مفهوم المفلس لغة وشرعاً، ومفهوم الغريم لغة وشرعاً الفرع الثاني: الوسطية في نفقة المفلس ومن يعولهم حفظاً لحق الغريم. الفرع الأول

مفهوم المفلس لغة وشرعاً، ومفهوم الغريم لغة وشرعا

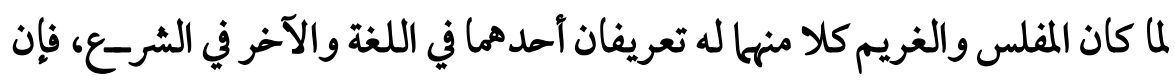
معالجة هذا الفرع، سوف تشتمل على أريع مسائل: المسألة الأولمه: تعريف المفلس لغة المسألة الثانية: تعريف المفلس شرعاً

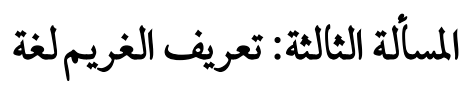

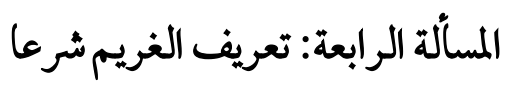

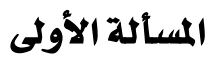 \\ تعريف المفلس لغة}

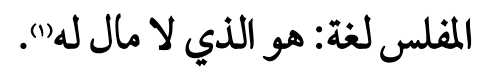

(') ابن السكيت، أبو يوسف يعقوب بن إسحاق(المثوفن: ع ع هـ)- الكنز اللغوي في اللَسَن العربي، مكتبة المتنبي ،

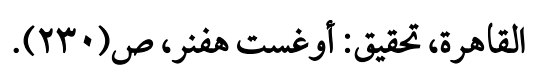




\author{
المسألة الثانية \\ تعريف المفلس ثرعاً \\ عرف فقهاء الشافعية المفلس شرعاً بأنه هو" من لا يفي ماله بدينه "(1)
}

المسالة الثالثة

تعريف الغريم لغة

الغريملغة: هو الذي له الدين والذي عليه الدين جميعاً (r).

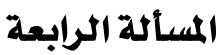 \\ تعريف الغريم شرعا \\ الغريم شرعاً:" يطلق علنى المدين وعلني صاحب الدين" (r)
}

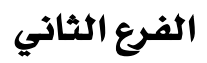

\title{
الوسطية يِّ نفقة المفلس ومن يعولهم حفظاً لحق الغريم أفرعيم
}

اتفق فقهاء الشافعية على أن المفلس إذا كان له كسب أنفق على نفسه من كسبه، وإذا لم

يكن له كسب، وحجر القاضي عليه، ومنعه من التصرف في ماله، فإنه ييب أن يترك له ولمن

تلزمه نفقتهم ما يكفيهم من النفقة الوسط من غير إسراف ولا تقتير (i).

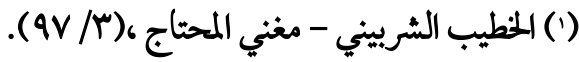

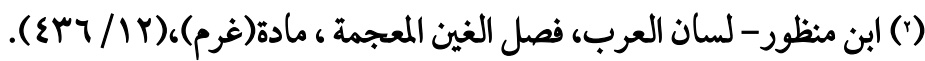

$$
\begin{aligned}
& \text { (r) النووي - المجموع شرح المذب،(T/7 (r) ). }
\end{aligned}
$$

(") حيث جاء في كلام فقهاء الشافعية عن المفلس ما نصه "ويترك له ما يحتاج إليه من الكسوة من غير إسراف ولا لإنا

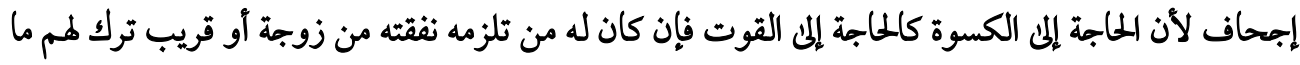

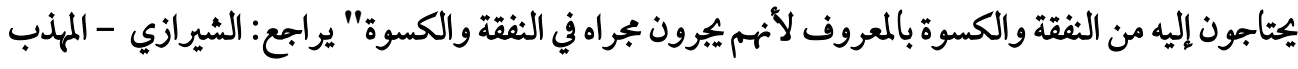

$$
\text { في فقه الإمام الشافعي (1) (1) }
$$




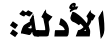

استدل فقهاء الشافعية على وجوب ترك الو سط من النفقة للمفلس ولمن تلزمه نفقتهم، ويعطى الباقي للغريم بمقدار ما له من ديون، بالكتاب الكريم، والســنة النبوية المطهرة، والمعقول.

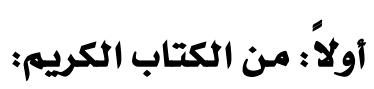

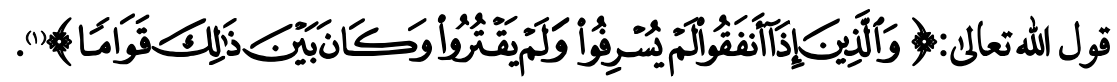

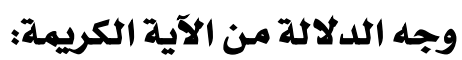
في هذه الآية الكريمة ذم الله عز وجل الإسراف في النفقة وهو ما جاوز الحد الذي أباحه الله لعباده إلى ما فوقه، والثقتير: وهو ما قصر، أي قل عما أمر الله به ومدح القوام: بين ذلك.

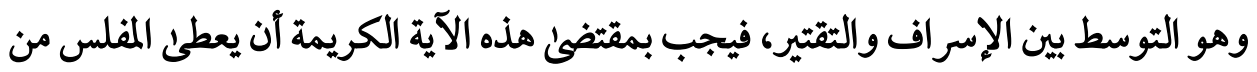

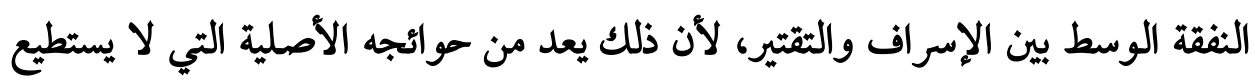

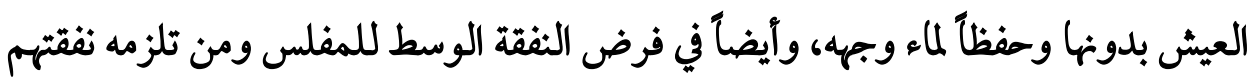
محافظة على حق الغريم إذل لو فرض للمفلس فوق النفقة الوسط لأضر ذلك بحق الغريم وعرض ماله للضياع، فالوسطية في النفقة تضمن للمفلس آن يعيش حياة كريمة وتضمن أيضاً للغريم آن يسترد حقه من المفلس (r). ثانياً: من السنة النبوية المطهرة:

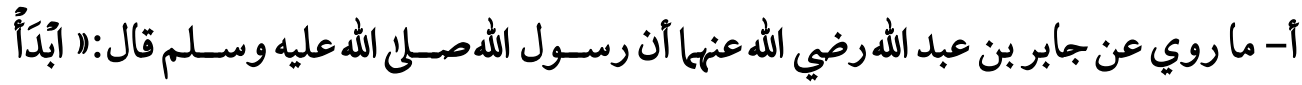

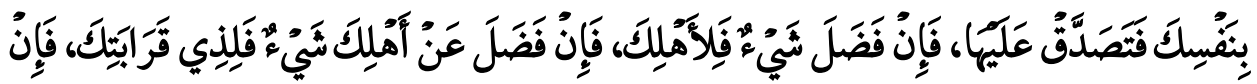

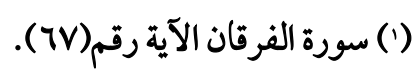

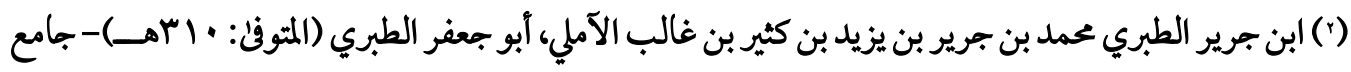
البيان عن تأويل آي القرآن، الناشر: دار هجر للطباعة والنشر والتوزيع والإعلان، الطبعة: الأولى، بrع أهـ

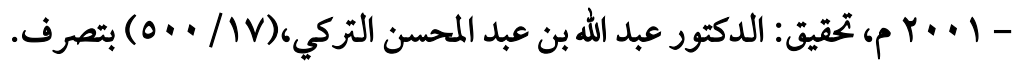




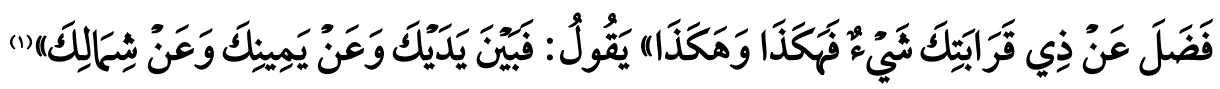
وجه الدلالة من الحديث الشريف:

في هذا المديث الشريف والذي يعد أساساً متيناً لفقه الأوليات ييين الرسول الكريمصلئ الله عليه وسلم وجوب مراعاة الترتيب الشرعي الفطري والتسلسل المنطقي بين الفرض والنافلة

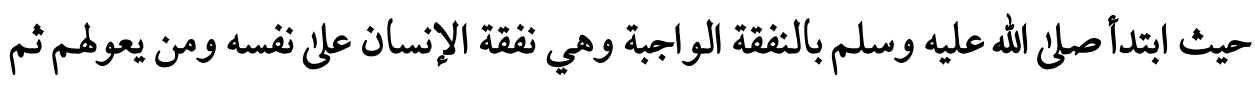
انتقل إلى صدقة التطوع فيفهم من ذلك أن الحقوق والفضائل إذا تزاحمت قدم الأوكد فلالأوكد، وأن الأفضل في صدقة التطوع أن ينوعها الإنسان في جهات اللخير ووجوه البر بحسب المصلحة

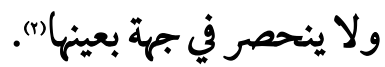
ب- ما روي عن إي هريرة رضي اللهعنه قال: جاء رجل إلى النبي صلن الله عليه وسلم فقال:

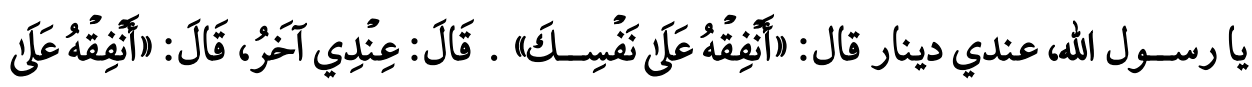

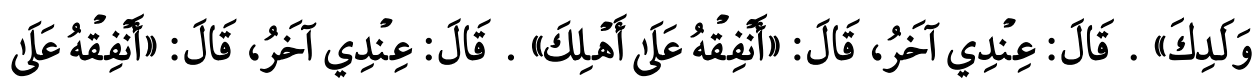

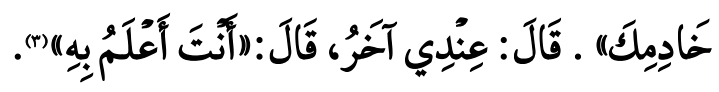

(1) أخرجه مسلم - صحيح مسلم، كتاب الكسوف، باب الابتداء في النفقة بالنفس ثم أهله ثم القرابة، حديث (Y) رهابث

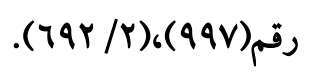

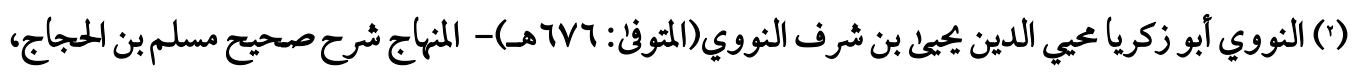

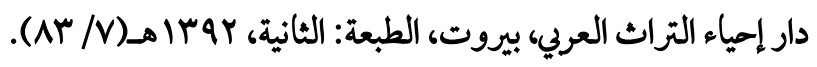

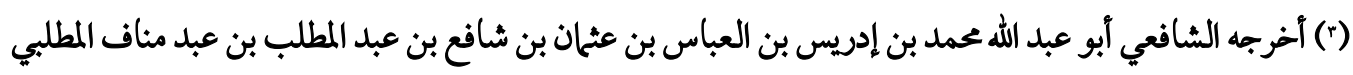

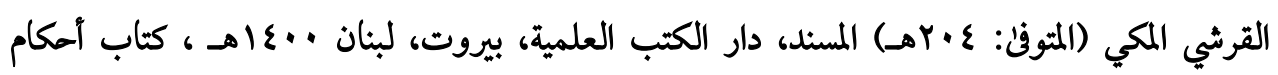
القرآن،(I/Tr/ r).

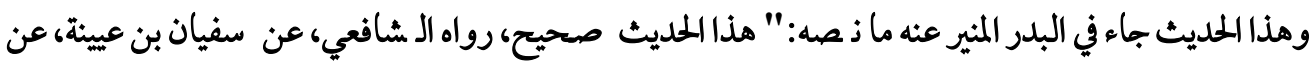

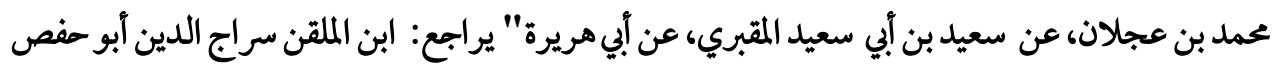

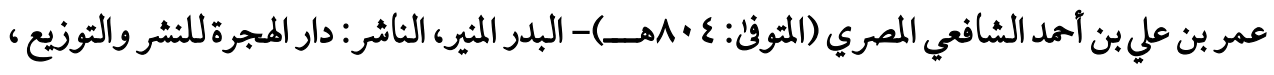

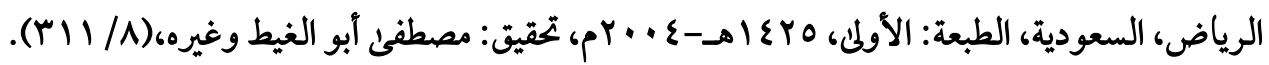


وجه اللالولة من الحلديث الشريف:

يدل هذ الحديث النبوي الشريف، كسابقه على وجوب مراعاة الأولوية في النفقة، ويدخل فيه ضــمناً المفلس، ومن تلزمه نفقتهم، فحقهم في الوسـط من النفقة محفوظ شرعاً، لاييوز المساس به والاعتداء عليه، حيث إن النبي صلي الله عليه وسلم أمره أن يبداً بنفسه، وعلني من يعول، ومعلوم آن فيمن يعول من تجب نفقته، وتكون ديناً عليه، وهي الزوجة، والأولاد، فعلم آن نفقته مقدمة على الدين، ويكون طعامه على ما جرت به عادته (1). ج- ما روي عن أبي سعيد الخدري رضي الله عنه، أن رسول اللهصلئ الله عليه وسلم قال:

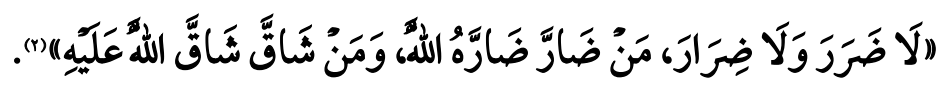

\section{وجه الدلالة من الحديث الشريف:}

يدل هذا الحديث النبوي الشريف على تحريم جميع أنواع الضرر، والضرار على آي صفة كان، فلايجوز في صسـورة من الصسور إلا بدليل يخص به هذا العموم، ومن ثم لا يجوز إلحاق الضرـر بالمفلس ومن يعولهم لمصـلحة الغرماء وذلك يتحقق بأخذ الغرماء جميع مال المفلس من غير أن يترك له شيء، ولا ييوز أيضاً إلحاق الضرر بالغرماء لمصلحة المفلس وذلك يتمثل في ترك جميع مال المفلس له يتمتع به كيف يشاء علإ حساب إلحاق الضرر بالغرماء، فالإسلام يرفض آن يحقق شخص مصلحة لنفسه على حساب ضرر الآخرين (r).

$$
\text { (') العمراني- البيان في مذهب الإمام الشافعي،(7/ (10) (10) بتصرف. }
$$

(') أخر جه الحاكم أبو عبد الله الحاكم محمد بن عبد الله بن محمد بن حمدو يه بن نُعيم بن الحكم الضسبي الطهياني

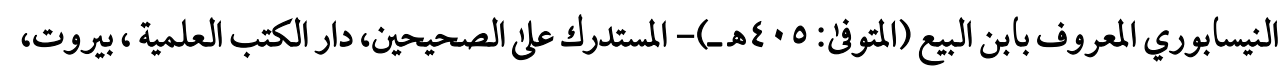

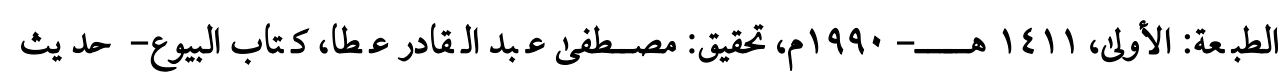

$$
\text { رقم) (TT/Y)، (YT\&O) }
$$

وهذا الحديث جاء فيه ما نصـه:" هذا حديث صـحيح الإســاد على شرط مسـلم ولميخرجاه " يراجع: الحاكم-

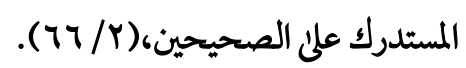

$$
\begin{aligned}
& \text { (r) الشوكاني - نيل الأوطار،(0/ / (r) بتصرف. }
\end{aligned}
$$


ثالثأً: من المعقول: وذلك من أريعة وجوه:

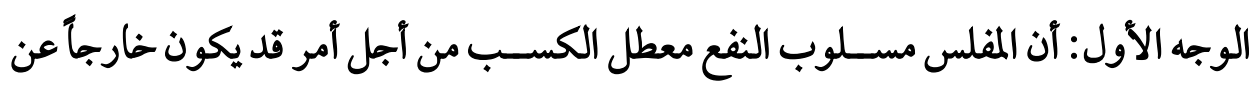
إرادته ولا دخل له فيه وربجا إذا اســتمر به هذا الأمر طويلاً أفقده آدميته ودفعه إلى التســول

$$
\text { وهو أمر يرفضه الإسلام رفضاً تامال(1). }
$$

الوجه الثاني: من المقرر شر عاً أن المفلس إذا لميكن له مال، فإن نفقته تكون واجبة على جميع

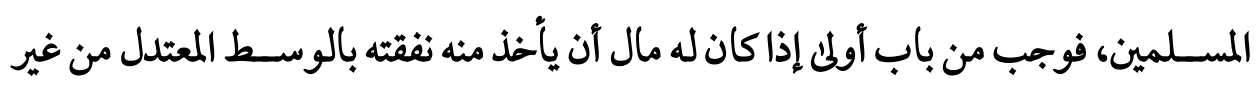

$$
\text { إسراف ولا تقتير (r) - (1) }
$$

الوجه الثالث: أن من تلزم المفلس نفقتهم يعاملون معاملة المفلس فيجب لهم من النفقة ما يكفيهم من غير إسراف ولا تقتير، لأن نفقتهم واجبة على المفلس، وذلك من باب ما لا يتم

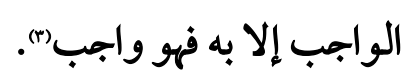

الو جه الرابع: أن المفلس إذالم يأخذ من النفقة ما يكفيه هو ومن يعولهم امتنع الناس من معاملته خوفاً من ضياع حقوقهم ، وفي ذلك تضييقاً عليه وإلحاق الضرر به (s).

\section{تعقيب وتعليق:}

ومن جميع ما سـبق تظهر عظمة الإسـلام ووسـطيته واعتداله وعدالته، حيث إن الإسـلام لم يترك للمفلس جميع المال ويتجاهل حقوق الغرماء وهم أصحاب الديون، وفي الوقت نفسه لم يعط الغرماء جميع مال المفلس ويتركه لا حول له ولا قوة يتمنى الموت في كل لحظة، ومن هذا يعلم آن الإسلام وازن بين المصلحتين مصلحة المفلس في أن يترك له من النفقة ما يكفيه ومن يعولمم بالمعروف من غير إسراف ولا تقتير، ومصلحة الغرماء في آن يأخذوا من مال المفلس

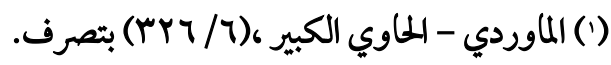

$$
\begin{aligned}
& \text { (r) (المرجع السابق نفس الموضع بتصرف. }
\end{aligned}
$$

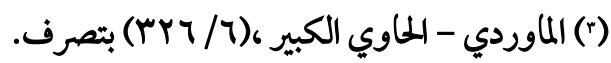

$$
\begin{aligned}
& \text { () العمراني- البيان في مذهب الإمام الشافعي،(7/ } 101 \text { ) بتصرف. }
\end{aligned}
$$




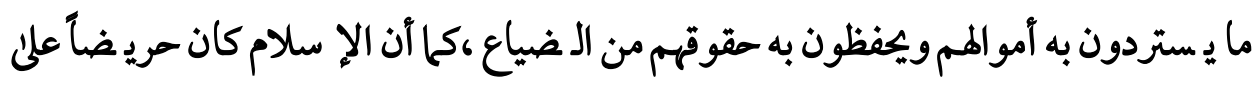

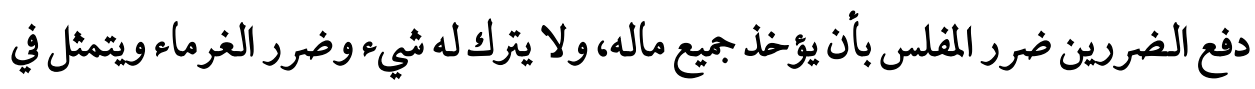

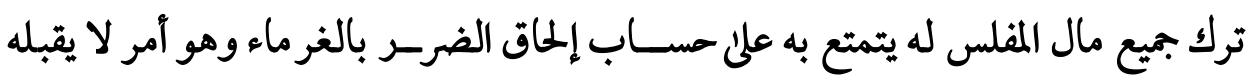
الإسلام لا من قريب ولا من بعيدل'. 


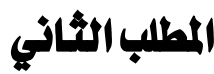

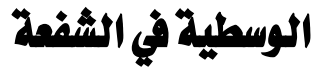

لملا كان اللحكم على الثيء فرع عن تصوره، فإن معالجة هذا المطلب سوف تشتمل على فرعين:

$$
\text { الفرع الأول: مفهوم الشفعة لغة وشرعاً. }
$$

الفرع الثاني: الوسطية في زمن ثبوت حق الشفعة.

الثرع|لأول

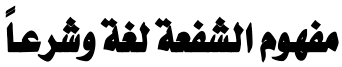

لما كانت الشفعة لها معنيان أحدهما في اللغة ، والآخر في الشرع فإن معالجة هذا الفرع مهرع سوف تشتمل علم مسألتين:

المسألة الأولى : مفهوم الشفعة لغة. المسألة الثانية: مفهوم الشفعة شرعاً.

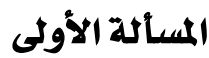

مفهوم الشفعة لغة

الشفعة لغة: مشتقة من الزيادة، لآن الشفيع يضم المبيع إلى ملكه فيشفعه به، كأثه كان واحداً وترا فصار زوجاً شفعاً).

\section{المسألة الثانية \\ مفهوم الشفعة ثرعاً}

عرف فقهاء الشافعية الشفعة شرعاً بأنها:" حق تملك قهري يثبت للشريك القديم على ملى الحادث بسبب الشركة بها يملك به لدفع الضرر" (().

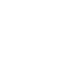

(') ابن الأثير - النهاية في غريب الحديث والأثر، ، باب الشين مع الفاء، مادة(شفع)،(Y / (1) ).

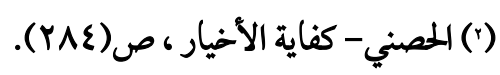




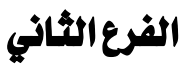 \\ الوسطية في زمن ثبوت جق الشفعة}

تحرير محل النزاع:

اتفق فقهاء الشافعية علي ثبوث حق الشفعة للشريك في الملك (")، واختلفوا في زمن ثبوته،

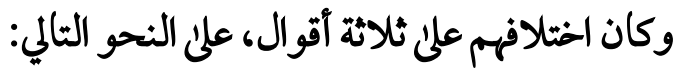

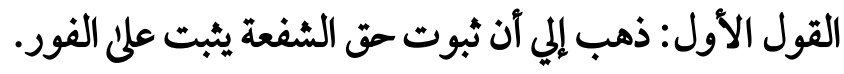

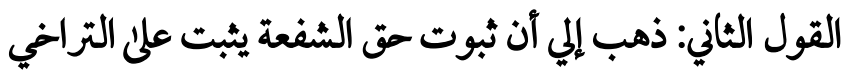
القول الثالث: ذهب إلي أن ثبوت حق الثب الشفعة يثبت المدة ثلاثة أيام.

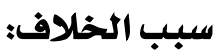
وكان سبب الملاف بين الفقهاء في هذه المسألة، هو اختلافهـ في عهدة الشفيع; هل هي على المائ

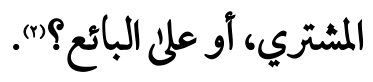

\section{וالألة:}

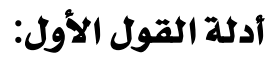

استدل أصحاب القول الأول القائلون بأن ثبوت حق الشفعة ثابت علئ الفور، بالسنة

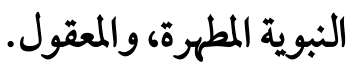

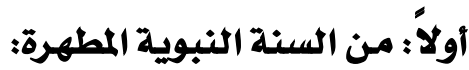

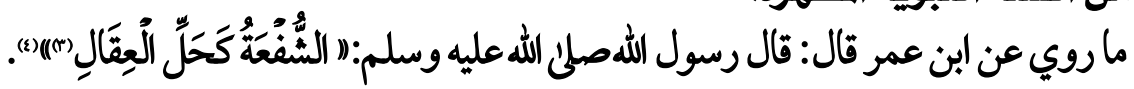

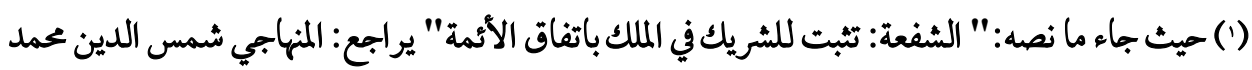

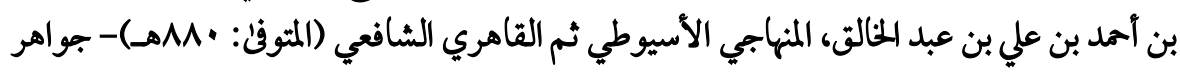

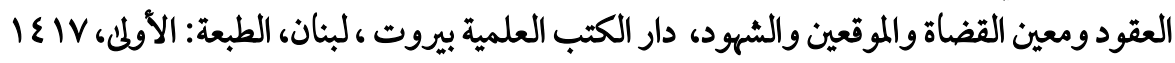

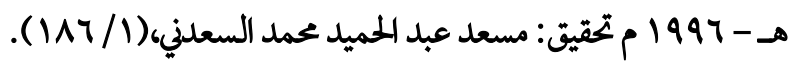

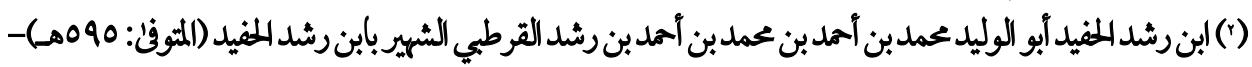

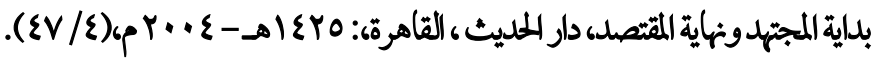

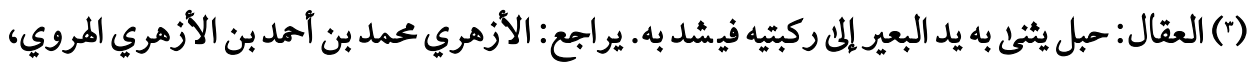

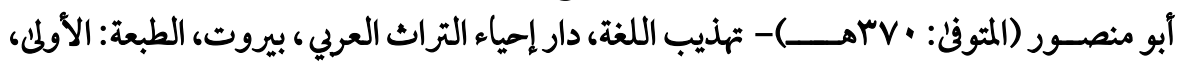

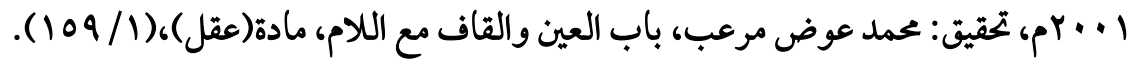

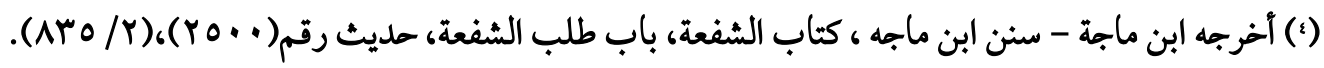

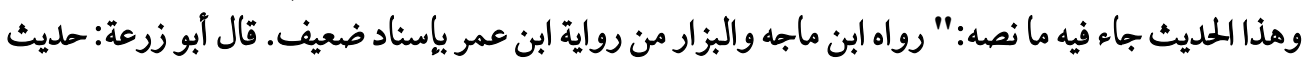

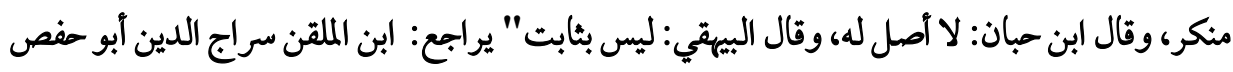




\section{وجه الدلالة من الحلديث الشريف:}

يدل هذا الحديث النبوي الشريف على أن حق الشفعة ثابت على الفور، حيث إن النبي صلنى الله عليه وسلم شبه ثبوت حق الشفعة للشفيع بالبعير الشرود عندما يفك ويحل رباطه إنهما لا شك فيه سوف يشردويذهب بعيداً فور حل رباطه ، وهذا يدل على أن الشفيع إذالميطالب

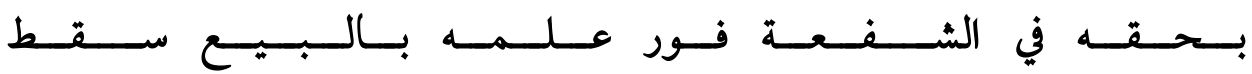

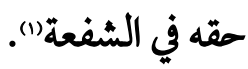

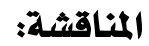

نوقش الحديث السابق: بأنه حديث ضعيف لا تقوم به حجة، وضعفه البزار، وقال ابن

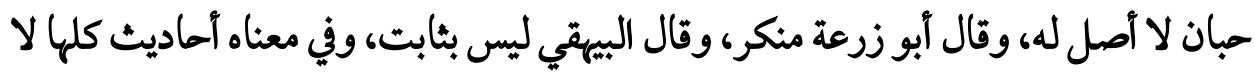
أصل لمان). (1) ثانياً: من المعقول: وذلك من وجهين: الوجه الأول: قياس ثبوت حق الشفعة علئ الرد بالعيب بجامع الفورية في كل، فإذا كان الرد

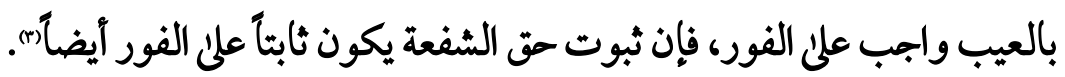
الوجه الثاني: أن الشفعة حق ثبت في المبيع لدفع الضرر عن الشفيع فيناسبه الفورية ل(s).

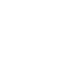

عمر بن علي بن أمد الشافعي المصري (المتوفن: ع • 1هـ)

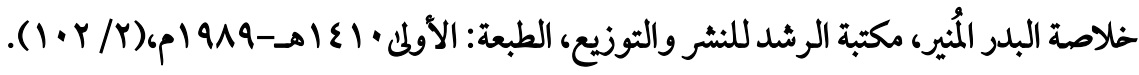

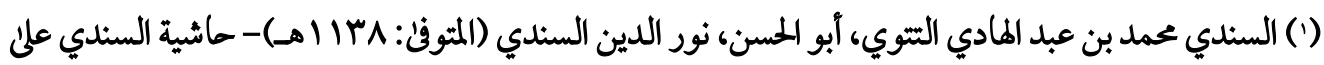

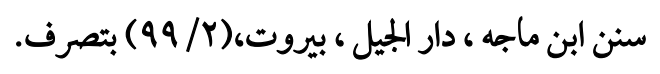

(') الصنعاني عحمد بن إسماعيل بن صلاح بن محمد الحسني، الكحلالني ثم الصنعاني، أبو إبراهيم، عز الدين، المعروف

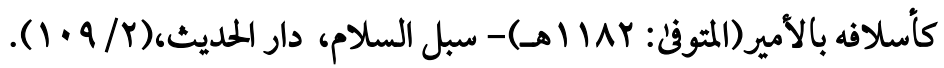

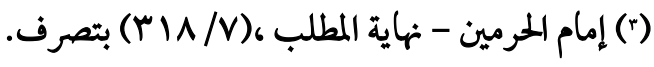

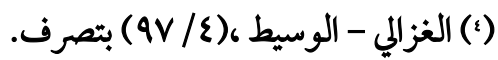


نوقش الدليل السابق: بأن الأصل عدم اشتراط الفورية وإثباتها يجتاج إلى دليل تقوم به الحجة، ولا يوجد دليل "). أدلة القول الثاني: استدل أصحاب القول الثاني القائلون بأن ثبوت حق الشفعة ثابت على التراخي، بالمعقول وذلك من وجهين:

الوجه الأول: قياس ثبوت حق الشفعة على ثبوت حق القصاص على التأبيد، بجامع الأبدية في كل "(.

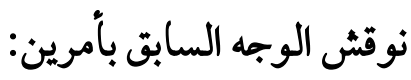

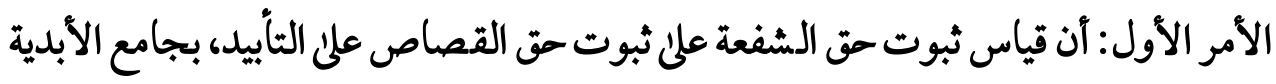

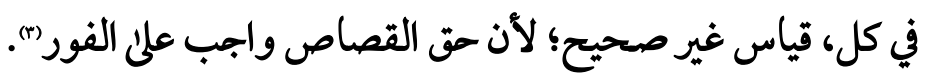

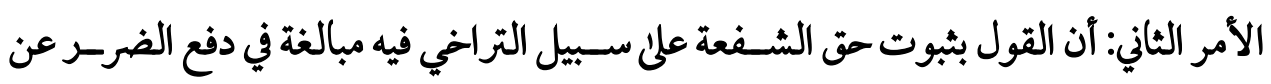
الشفيع، وإلحاق الضرر بالمشتري، ويتمثل ذلك في بقاء ما اشتراه معلقاً إلى أجل غير مسمئ، وهذا فيه تحيز ظاهر لمصلحة الشفيع علئ حساب ضرر المشتري(1)، والقاعدة الفقهية تقول:" الضرر لا يزال بالضرر"

الوجه الثاني: أن ثبوت حق الشفعة ثابت علئ التراخي، لأنه يترتب عليه تمليك المبيع بالثمن قياساً

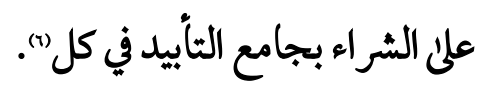

$$
\begin{aligned}
& \text { (') الصنعاني - سبل السلام،(Y/9 ( ) ). }
\end{aligned}
$$

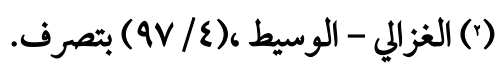

$$
\begin{aligned}
& \text { (r·V/T)، بتصرف. (r) المصدر السابق } \\
& \text { (2) الصنعاني - سبل السلام،(Y/ ( + () بتصرف. } \\
& \text { (0) السيوطي - الأثباه والنظائر، ص(1)). }
\end{aligned}
$$

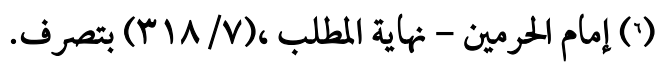


نوقش الوجه السابق: بأن قياس ثبوت تأبيد حق الشفعة علئ تأبيد الشراء قياس غير صحيح،

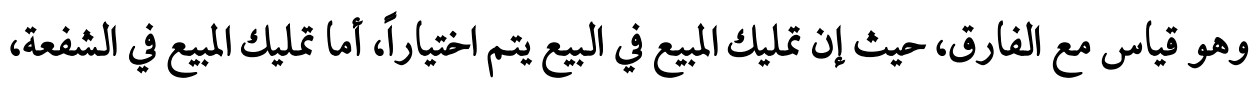

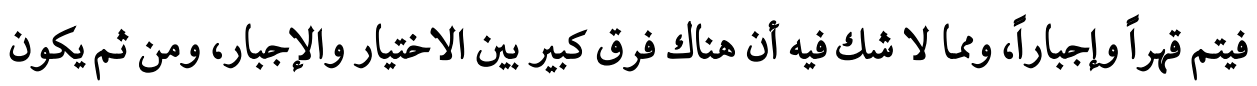

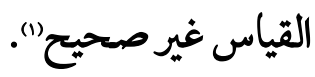
أدلة القول الثالث: استدل أصحاب القول الثالث القائلون بأن ثبوت حق الشفعة ثابت لمدة ثلاثة أيام،

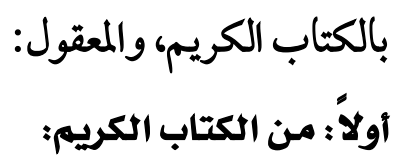

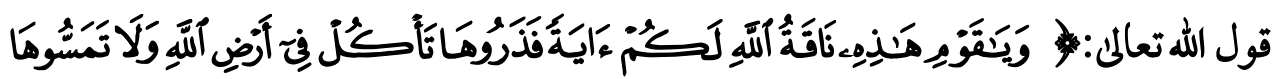

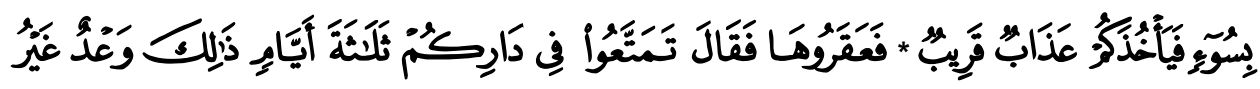

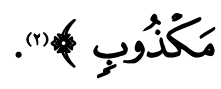

\section{وجه الدلالة من الآية الكريمة:}

في هذه الآية الكريمة أنظر الله عز وجل المجرمين لنزول العذاب بهم ثلاثة أيام، فيكون الانظار في الأمكام الشرعية أولى (ت).

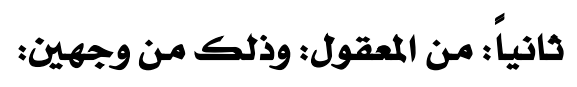
الوجه الأول: أن في القول بثبوت حق وجهئ الشفعة على الفور إضرار بالشفيع، لأنه قديحتاج

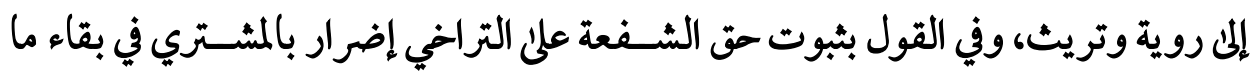

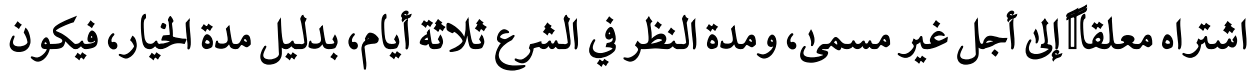

$$
\begin{aligned}
& \text { (') (') (1) من فهم الباحث. } \\
& \text { (1) سورة هود الآيتان رقم(ع (10-70). }
\end{aligned}
$$

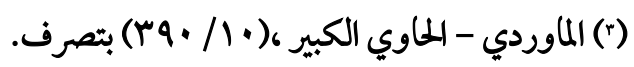


تقدير المدة بثلاثة أيام له أصل في الشرع يرجع إليه عند النزاع").

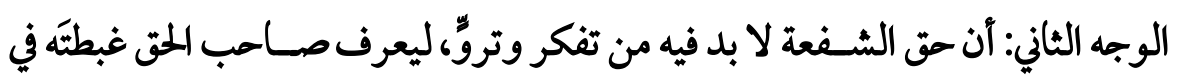

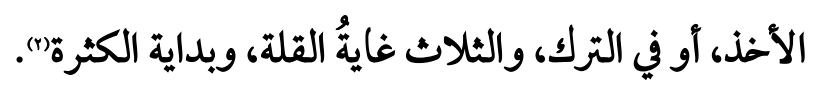
القول المختار:

بعد عرض الأراء وذكر الأدلة والمناقشات، يتبين آن القول المختار هو القول الثالث والآخير القائل بأن حق الشفعة ثابت للشفيع لمدة ثلاثة أيام وذلك لعدة أسباب أهمها: السبب الأول: قوة أدلة هذا الرأي وسلامتها من المناقشة، وضعف أدلة القولين الآخرين.

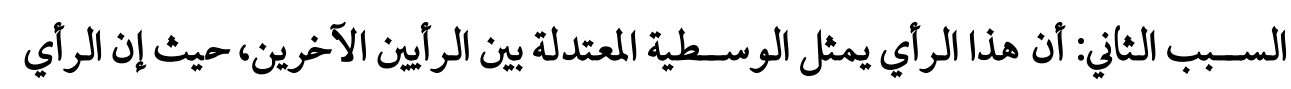

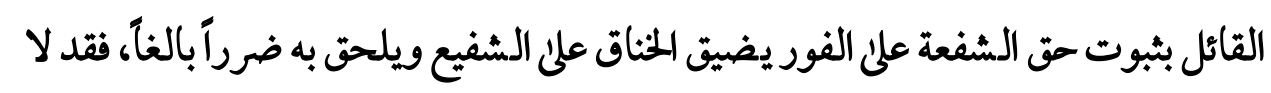

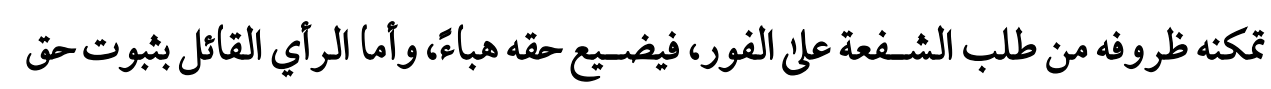

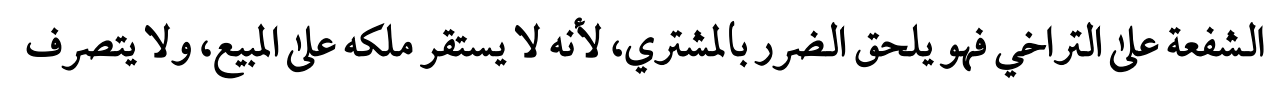
فيه بعحارة، خوفًا من أخذ المبيع وضياع عمله.

السبب الثالث: أن هذا الرأي راعلى مصلحة الطرفين الشفيع والمشتري ودفع الضرر عنها، أما

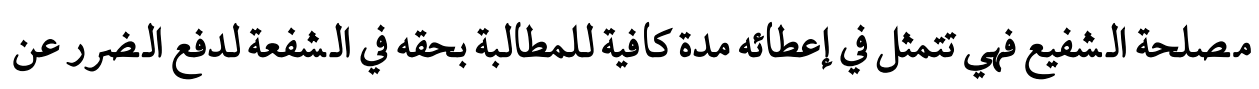
نف سه، وأما م صلحة المشتري فهي تتمثل في عدم انتظاره طويلاً وأخذه قراراً حا سماَ بشأن المبيع الذي آقدم علئ شرائه. السبب الرابع: أن تحديد ثبوت حق الشفعة بثلاثة أيام له أصل في الشرع يرجع إليه عند النزاع،

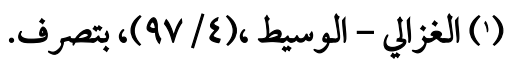

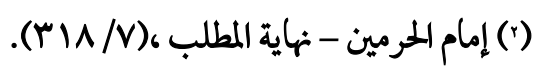


ومنها علئ سـبيل المثال لا الحصر-خيار الشر-ط(1)، وإمهال تارك الصـلاة عمدآ()، واسـتابة

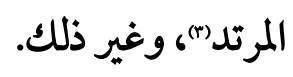
تعقيب وتعليق: إن الو سطية تظهر وا ضحة جلية في اختلاف الفقهاء في هذه المسألة ، إذلو كان في المسألة قولاً

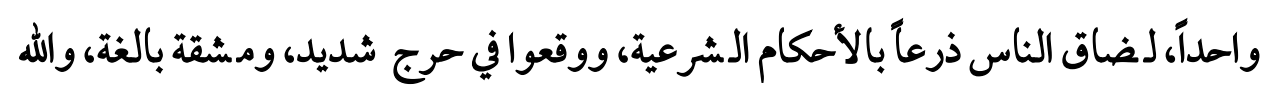

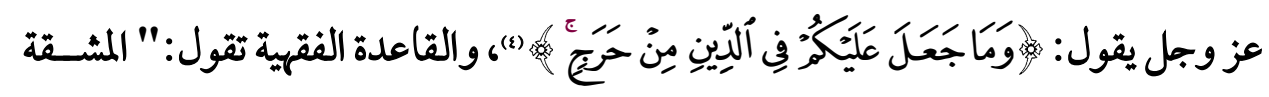

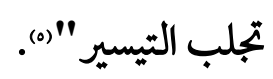

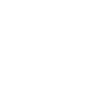

(') حيث جاء ما نصه:" فإذا تشارط المتبايعان الميار ثلاثة أيام، ثبت، وإن شرطاه أقل من ذلك، ثبت المشروط بلا

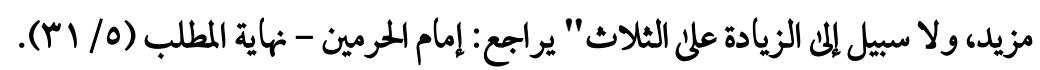

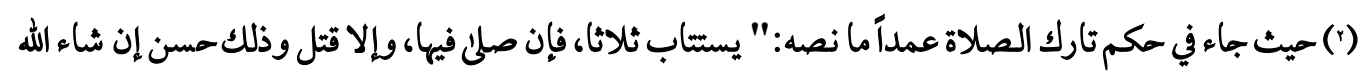

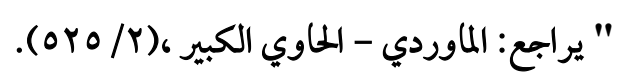

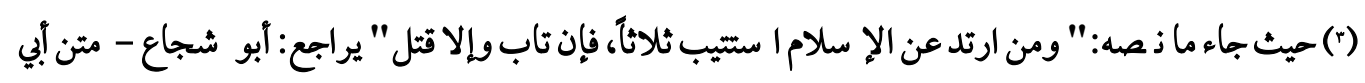

$$
\begin{aligned}
& \text { شجاع، (•ع). }
\end{aligned}
$$

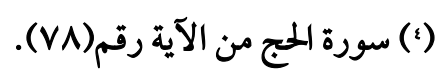

$$
\begin{aligned}
& \text { (•) السبكي - الأشباه والنظائر،(1/ ع ع). }
\end{aligned}
$$




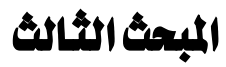

\section{ثماذج تطبيقية من الوسطيلة في ثقه الأحوال الشهمصية}

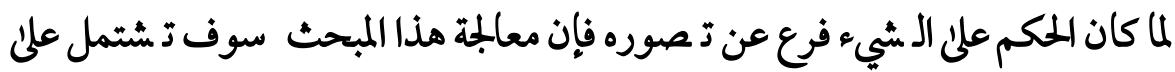

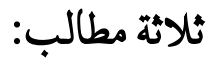

المطلب الأول: مفهوم الأحوال الشخصية.

المطلب الثاني: الوسطية في مقدار نفقة الزوج على زوجته.

المطلب الثالث: الوسطية في مقدار المهر.

\section{المطاب الأول}

\section{مفهوم الأحوال التشخصية}

الأحوال الشـخصـية: هو اصـطلاح قانوني أجنبي يقابل الأحوال المدنية أو المعاملات

المدنية، وقسم الجنايات، وقد ا شتهر في الجامعات، وأصبح عنوان التأليف في أحكام الأسرة، ويراد به الأحكام التي تتصل بعلاقة الإنسان بأسرته، بدءاً بالزواج، وانتهاء بتصفية التركات أو الميراث، وهي تشــمل : أحكام الأسرة من خطبة وزواج وحقوق الزوجين من مهر ونفقة، وحقوق الأولاد من نســب ورضــاع ونفقات، وانحلال الزواج بإرادة الزوج كالطلاق والخلع، أو بالتفريق القضـائي كالإيلاء واللعان والظهار، والتفريق للعيب والغيبة والضرـر وعدم الإنفاق، وأحكام الأهلية والولاية والوصــاية على الصــير، وأحكام أحكام آموال الأسرة من ميراث، ويسـمـئ فقهاً (الفرائض) ، ووصــايا وأوقاف ونحوها مما يعد تصريـفاً مضافاً لما بعد الموت، وقد حددت الملادة (r ) من قانون القضاء في مصر، رقم (VV I ) لسنة (9 (9 |م) ما يعد من الأحوال الشخصية، وهي الفئات الثلاث السابقة، و صدرت قوانين الأحوال الشخصية في سورية وتونس والأردن والعراق والمغرب الأقصى متضمنة أحكام الزواج والأهلية والو صاية على ال صغير والو صية، والإرث، إلا آن قانون العراق المشتمل علنى أحكام المذهبين السني والجعفري لميتضمن كل آحكام الأحوال الشخصية، وهو فيها عدا 
المذهب المعفري اختصار لكتاب الأمكام الشرعية في الأحوال الشخصية لقدري با شا على مذهب المنفية. وصـدر في مصر- قوانين خاصـة بالميراث عام (بع 19 ام) ، والوقف عام

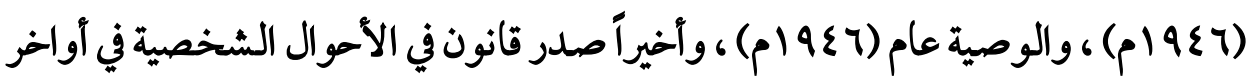

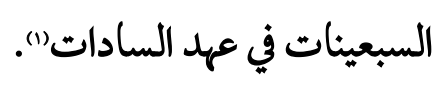

\section{المطالب الثاني}

\section{الوسطية في مقدار نفقة الزوج على زوجته}

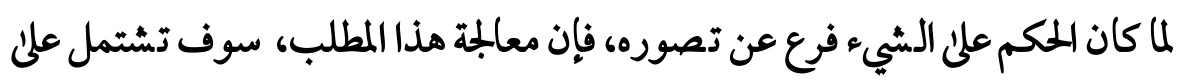

$$
\begin{aligned}
& \text { فرعين: } \\
& \text { الفرع الأول: مفهوم النفقة لغة وشرعاً. } \\
& \text { الفرع الثاني: الوسطية في مقدار نفقة الزوج على زوجته. } \\
& \text { الفرعالأول } \\
& \text { مفهوم النفقة لفة وشرعاً }
\end{aligned}
$$

لما كانت النفقة لها معنيان، أحدهما في اللغة، والآخر في الشرع، فإن معلجة هذا الفرعاع

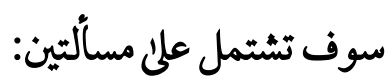
المسألة الأولى: مفهوم النفقة لغة.

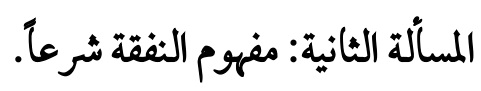

(') الأستاذ الدكتور/ وهبة الزهيلي - الفقه الإسلامي وأدلته، دار الفكر، سورية ، دمشق، الطبعة: الرابعة، (4 (). 


\section{المسالة الأولى}

\section{مفهوم النفقة لغة}

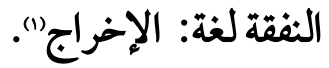

\section{المساكلة الثانية \\ مفهوم النفقة ثرعاً}

النفقة شرعاً: الإخراج في الخير(()، ونفقة الزوجة تشــمل الطعام، والإدام، والكســوة، مهومة

وآلة التنظيف، ومتاع البيت، والسكنى، وخادم إن كانت ممن تخدم"(r).

$$
\text { الفرع الثاني }
$$

الوسطية ِِّ مقدار نفقة الزوج على زوجته

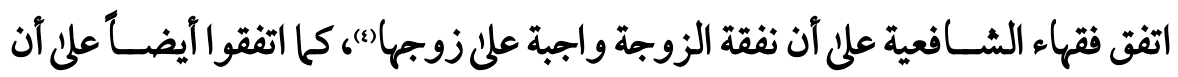
مقدار النفقة يختلف باليسار والإعسار والتو سط(0)، وضابط اليسار والإعسار والتو سط هو العادة وهي تختلف باختلاف الأحوال والبلاد، فالموسر من يزيد دخله على خرجه، والمعسر -

(') النووي أبو زكريا محيي الدين يجيحل بن شرف النووي(المتوفن: جVاجهـ- تحرير ألفاظ التبيه، دار القلم ، دمشق،

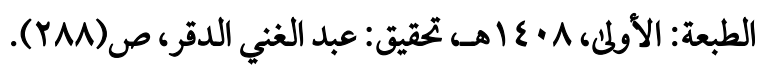

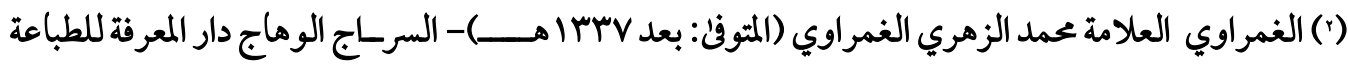

$$
\text { والنشر، بيروت، ص(10) الخطيب الشربيني - مغني المحتاج، (10). }
$$

(؛) حيث جاء ما نصه:" إذا سلمت المرآة نفسها إلى زوجها وتمكن من الاستمتاع بها ونقلها إلى حيث يريد ومها من أهل الاستمتاع في نكاح صحيح وجبت نفقتها" يراجع: الشيرازي - المهذب في فقه الإمام

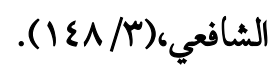

(•) حيث جاء ما نصه:" ونفقة الزوجة الممكنة من نفسها واجبة وهي مقدرة إذا كان الزوج موسرا فمدان من غالب قوتها ومن الأدم والكسوة ما جرت به العادة وإن كان معسر افمد وما يتأدم به المعسرون ويكتسونه، وإن كان إنها متوسطا فمد ونصف ومن الأدم والكسوة الوسط " يراجع: الحصي - كفاية الأخيار ،ص(1 عـى). 
من يزيد خرجه علئ دخله ، والمتوسط من تساوئ خرجه ودخله (1).

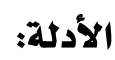

أ- أدلة وجوب نفقة الزوج على زوجته:

اسـتدل فقهاء على وجوب نفقة الزوج على زوجته، بالكتاب الكريم، والسـنة النبوية المطهرة، والمعقول:

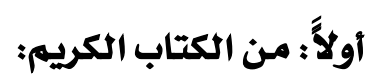

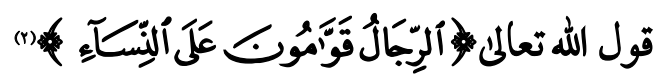

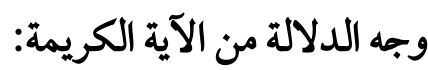

في هذه الآية الكريمة جعل الله عز وجل للرجل القوامة على زوجته، بمقتضئ عقد

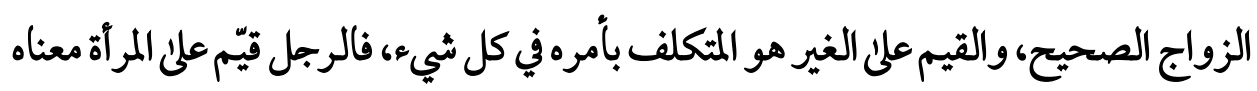
قائم عليها بلمحاية والرعاية والنفقة، فدل ذلك علئ وجوب نفقة الزوجة على زوجها، وهو

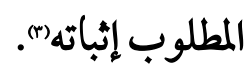

ثانياً: من السنة النبوية المطهرة:

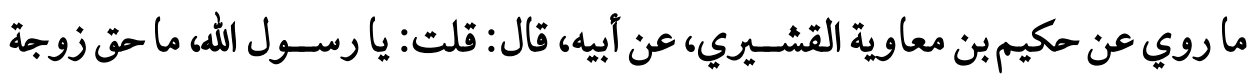

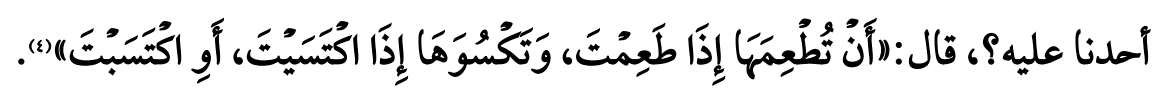

$$
\begin{aligned}
& \text { (') النووي - روضة الطالبين،(9/ 1ع) بتصرف. } \\
& \text { (r) سورة النساء الآية رقم(ع)). }
\end{aligned}
$$

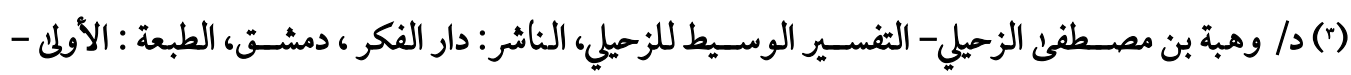

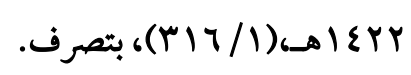

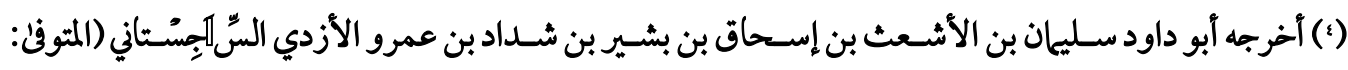

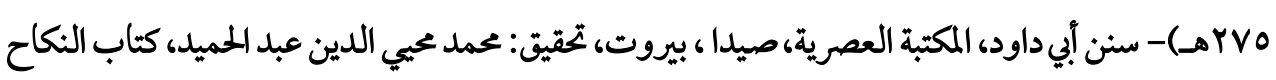

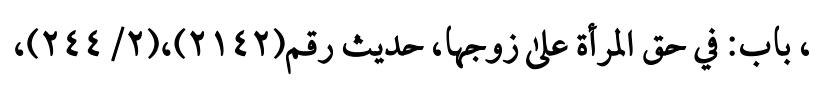

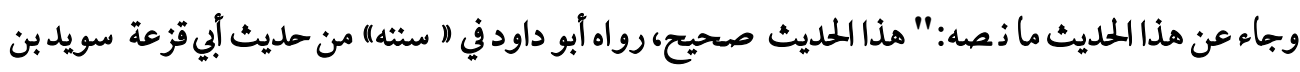


وجه الدلالة من الحديث الشريف:

في هذا الحديث الشر-يف دلالة واضسحة على إيباب النفقة للزوجة على زوجها، حيث جعله النبي صلئ الله عليه و سلم حقاً لما فهو لازم على الزوج لزوجته في الحضر والسفر، وإن لميجده في وقته كان ديناً عليه إلى أن يؤديه إليها كسائر الحقوق الواجبة"). ثالثاً: من المعقول: وذلك من وجهين: الوجه الأول : أن نفقة الزوجة معاو ضة في مقابلة الا ستمتاع بها، فلما ملك الاستمتاع مدون ملك عليه ما في مقابلته من النفقة). الوجه الثاني: أن الزوجة محبوســة عن التكسـبـ لحق الزوج، فوجبت لما النفقة علئ زوجها، بمقتضى_ هذا الاحتباس الكامل (r)، تطبيقاً عملياً للقاعدة الفقهية التي تقول " الغرم

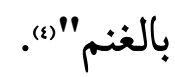

ب- أدلة اختلاف مقدار نفقة الزوج على زوجته باليسار والتوسط والإعسار. ا ستدل فقهاء المشافعية على اختلاف مقدار نفقة الزوج على زوجته، باليسار والتو سط والإعسار ، بالكتاب الكريم، والسنة النبوية المطهرة، والمعقول.

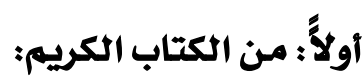

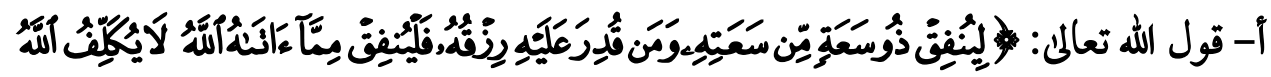

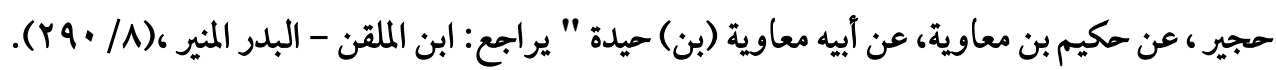

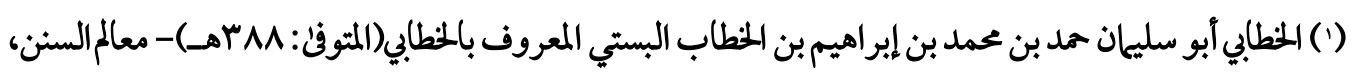

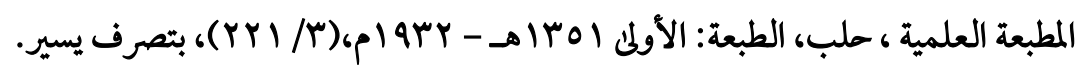

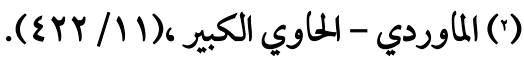

$$
\begin{aligned}
& \text { (') النووي- المنهاج شرح صحيح مسلم ، (9/ • (0) بتصرف. }
\end{aligned}
$$

(؛) الدكتور محمد مصـطفى الزحيلي- القواعد الفقهية وتطبيقاتها في المذاهب الأربعة، دار الفكر ، دمشـق، الطبعة:

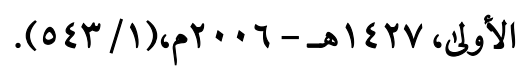




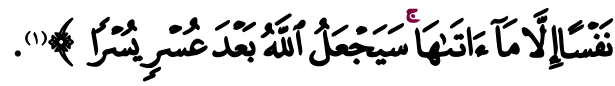

\section{وجه الدلالة من الآية الكريمة:}

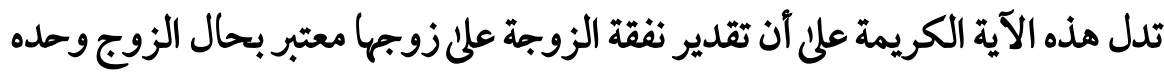

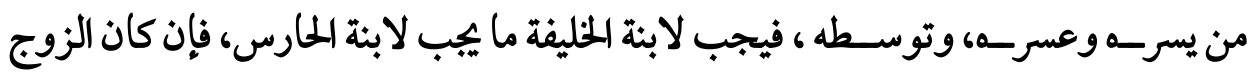

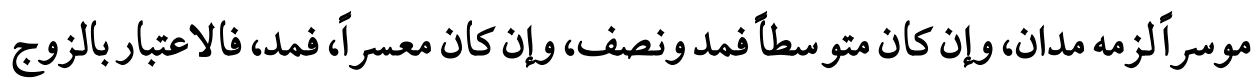
في اليسر-والعسر-والتوسط دون الزوجة، لآن الاعتبار بكفاية الزوجة لا سـبيل إلى علمه للحاكم ولا لغيره، فيؤدي إلى الخصــومة، لأن الزوج يدعي أنها تلتمس فوق كفايتها، وهي

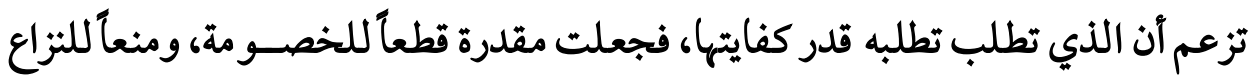

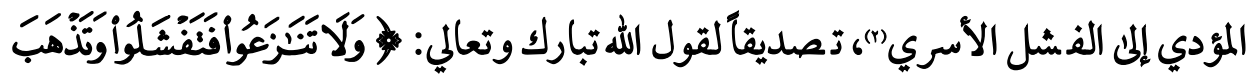

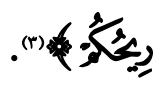

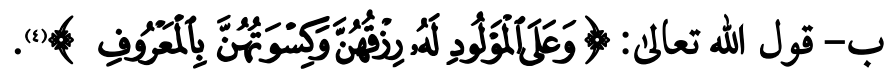

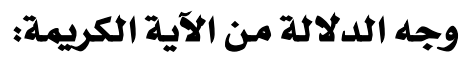

في مذه الآية الكريمة أوجب اللهزئ وجل علئ الزوج وهو المولود له في الآية الكريمة النفقة على زوجته بالمعروف، ويعني بقوله:" بالمعروف"، بها يجب لمثلها علن مثله، إذ كان الله

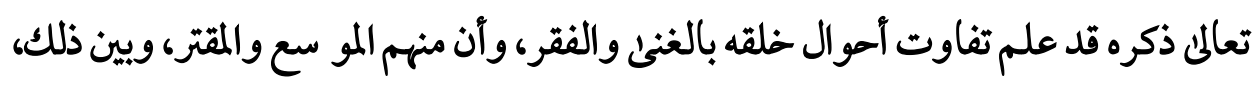

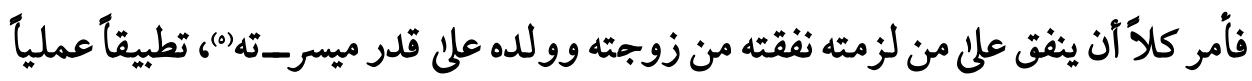

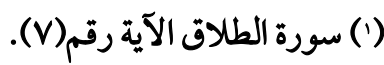

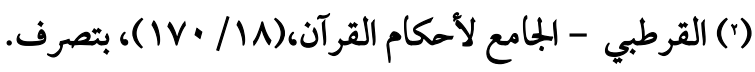

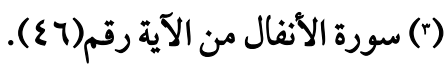

$$
\begin{aligned}
& \text { (؛) سورة البقرة من الآية رقم(YMr). }
\end{aligned}
$$

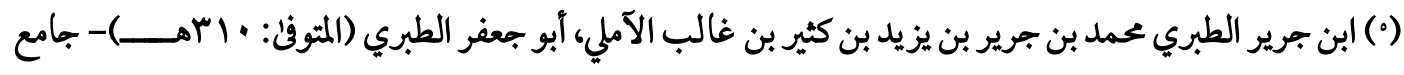

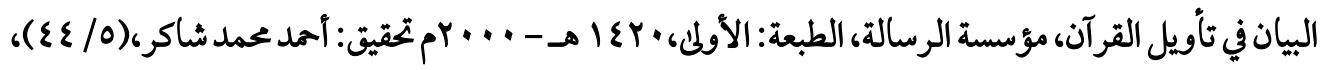


للقاعدة الفقهية التي تقول "العادة محكمة"(1)، والقاعدة الفقهية التي تقول:" المعروف عرفاً

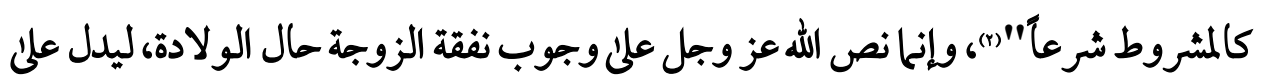

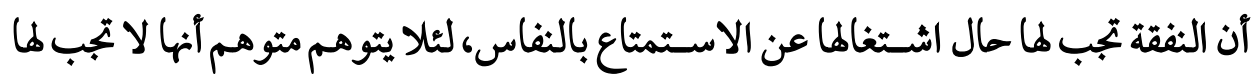
في هذه الحالة، وهذه وســية وعدالة منقطعة النظير، حيث إن المرآة في حال النفاس تكون أ شد ضعفاً، وأ شد احتياجا إلى النفقة، ومنع الزوج من الا ستمتاع بزوجته في حال النفاس ، ليس للمرأة دخل فيه، وإنما هو حكم شرعي"ه (r).

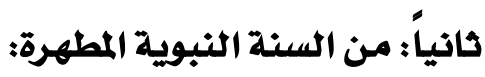
أ- ما روي عن عائشـــة رضي الله عنها، أن هند بنت عتبة، قالت: يا رسـول الله إن أبا سـفيان

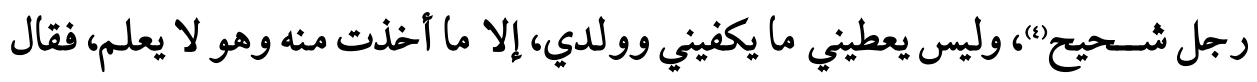

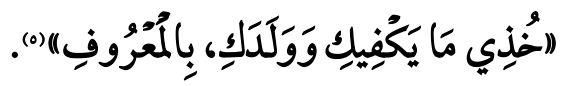
وجه الدلالة من الحديث الشريف:

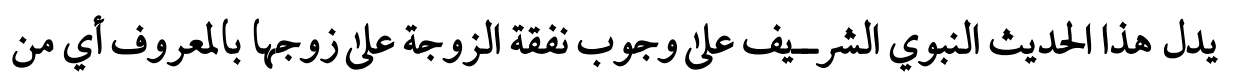
غير سرف ولا تقتير، حيث أذن الرسول الكريم صلنى الله عليه و سلم لمند بنت عتبة زوجة أبي

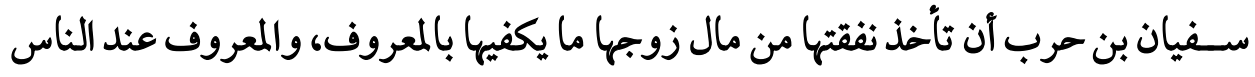
يختلف بيسار الزوج وإعساره، وتوسطه، وهنا تظهر وسطية الإسلام وعدالته في مراعاة حال الزوج المنفق علن زوجته، و حال الزوجة المنفق عليها، منعاً لوقوع الظلم بأحد هما فلم يقل

$$
\begin{aligned}
& \text { بتصرف. } \\
& \text { (') السيوطي - الأثباه والنظائر، ص (19). }
\end{aligned}
$$

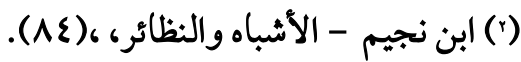

$$
\begin{aligned}
& \text { (r) المنهاجي - جواهر العقود،(r/ (179 ) بتصرف. }
\end{aligned}
$$

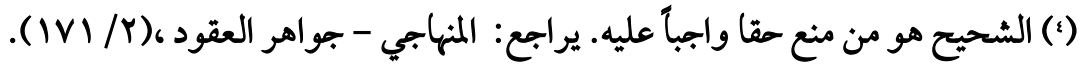

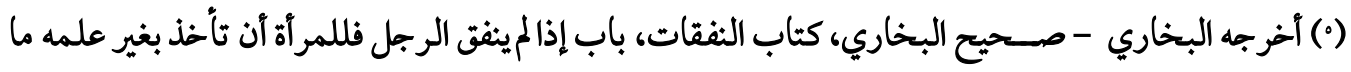

$$
\text { يكفيها وولدها بالمعروف، حديث رقم(ع (70/V)، (70). }
$$


الرسول عليه الصلاة والسلام لزوجة أبي سفيان خذئ ما يكفيك وفقط، لأن ذلك لو حدث،

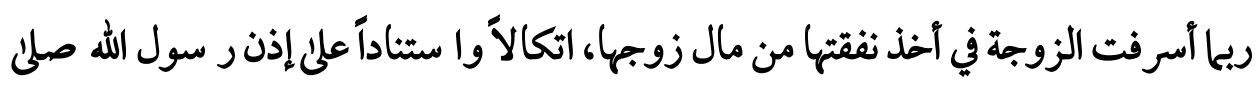

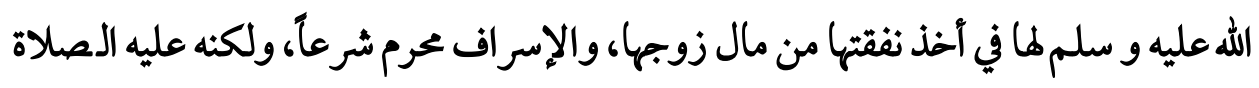

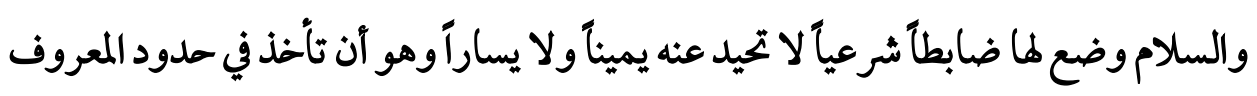
من غير إسراف ولا تقتير بحسب هال زوجها يساراً وإعساراً وتوسطاًا).

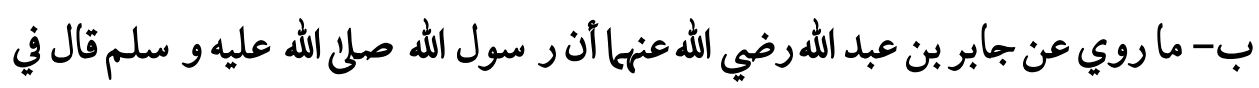

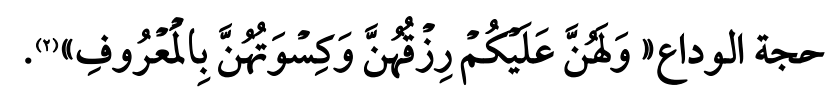
وجه الدلالة من الحديث الشريف: يدل هذا الحديث الشريف علنى وجوب نفقة الزوجة وكسوتها على زوجها بالمعروف وقوله:

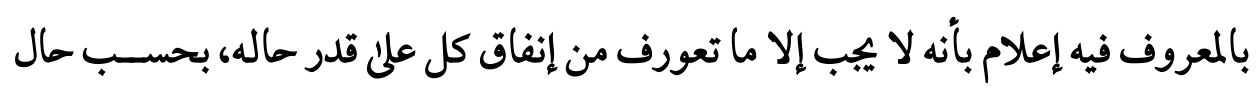

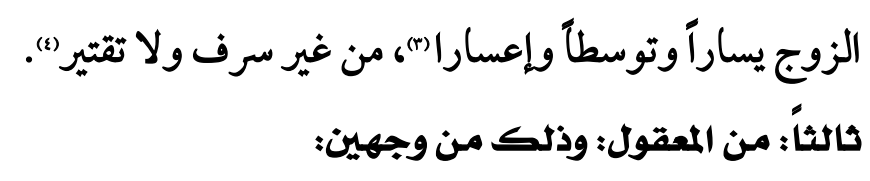
الوجه الأول: أن نفقة الزوجة على زوجها معتبرة بحال الزوج لا بحال الزوجة؛ فيجب لابنة

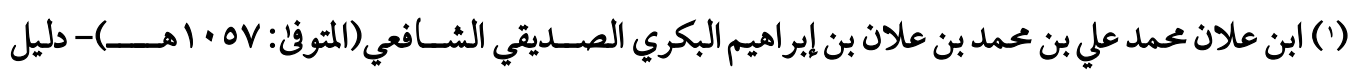

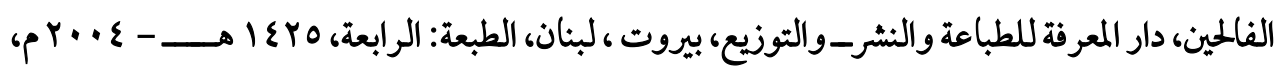

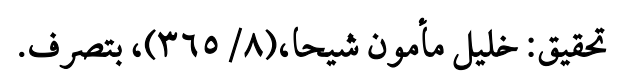

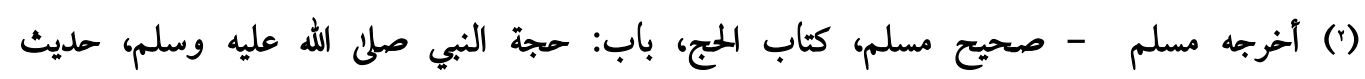

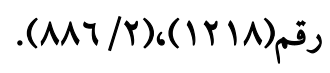

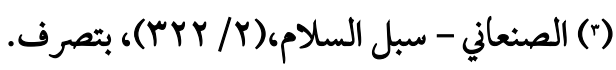

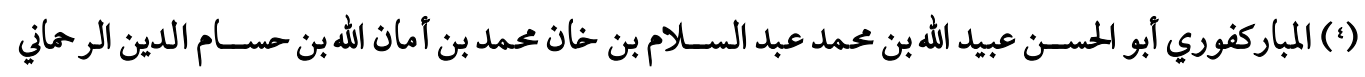

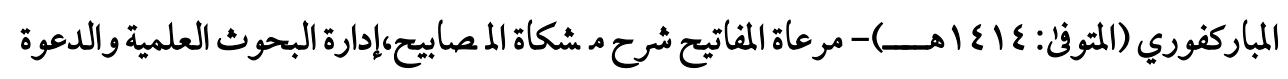

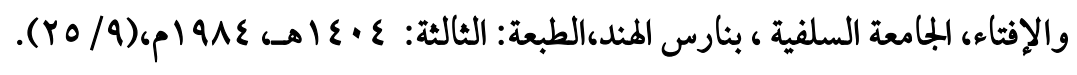


الخليفة ما يجب لابنة الحارس، وهي مقدرة غير معتبرة بكفايتها')،لأن نفقة الزوج على زوجته

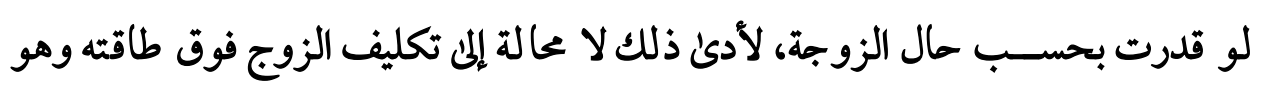

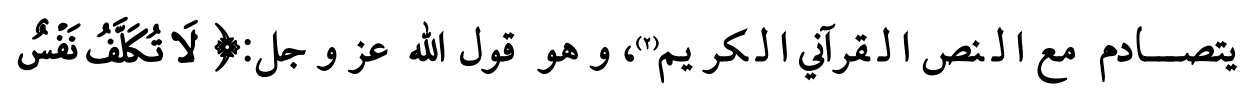

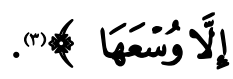
الوجه الثاني: قاس فقهاء الثـافعية نفقة الزوجة على الكفارة بجامع أن كلاً منها مال ييب

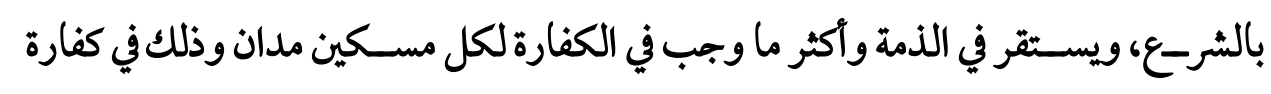
الأذنى في الحج، وأقل ما وجب له مد في نحو كفارة الظهار، فأوجبوا علنا الموسر الأكثر وهو

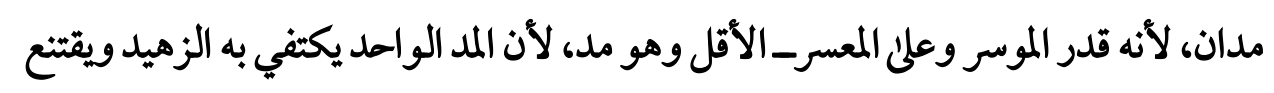

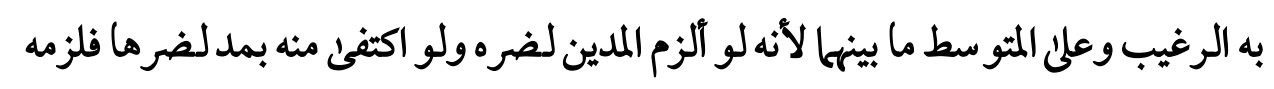

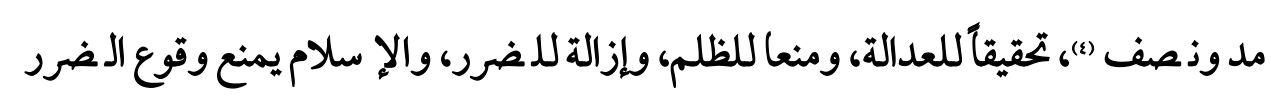

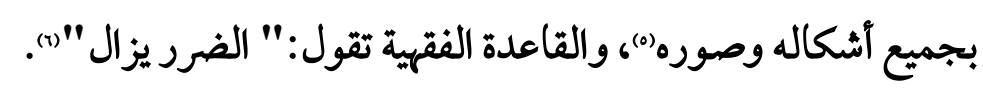

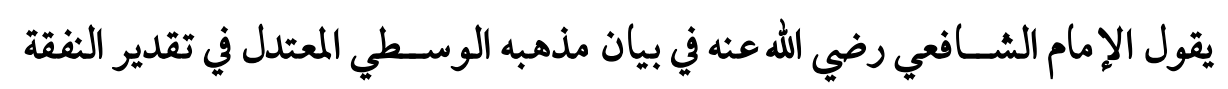
الواجبة على الزوج لزوجته، واختلاف مقدارها بحسب حال الزوج يساراً وتوسطاً وإعساراً

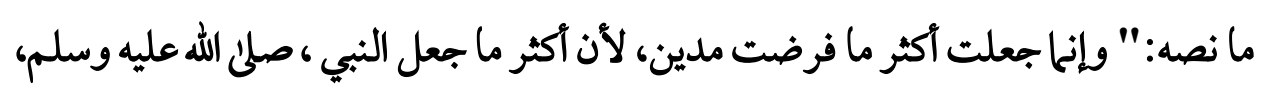

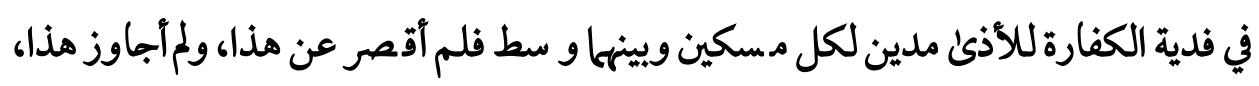

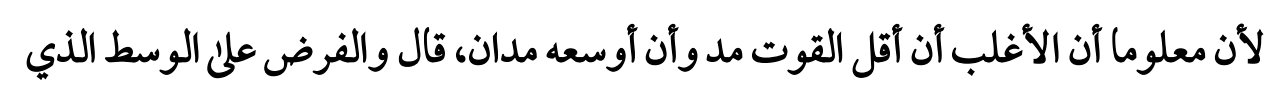

$$
\begin{aligned}
& \text { (1) العمراني - البيان في مذهب الإمام الشافعي،(1) (Y / (Y). }
\end{aligned}
$$

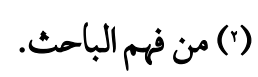

$$
\begin{aligned}
& \text { (() سورة البقرة من الآية رقم(بساب). }
\end{aligned}
$$

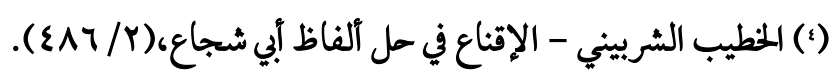

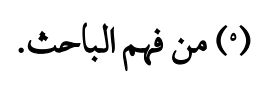

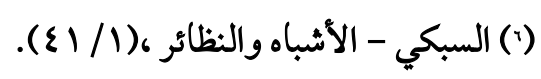


ليس بالموسع ولا بالمقتر ما بينها مدونصف للمرأة" (1). ويقول إمام الحرمين: في بيان الأساس الذي بنئ عليه الإمام الشافعي مذهبه في تقدير نفقة الزوجة الواجبة على زوجها واختلاف مقدارها باليسار والتو سط والإعسار ما ذصه:" فلما لئل

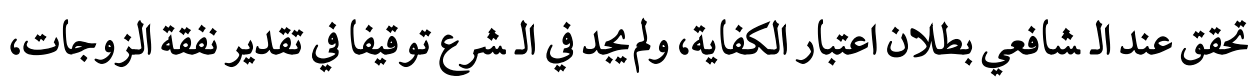

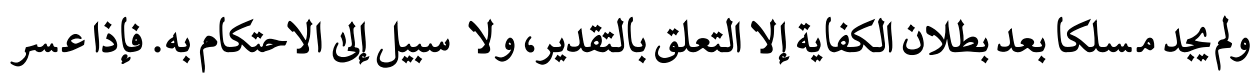

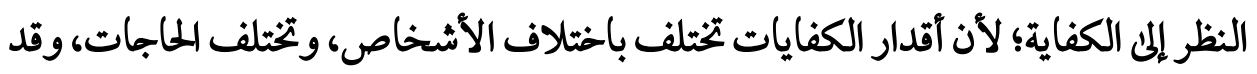

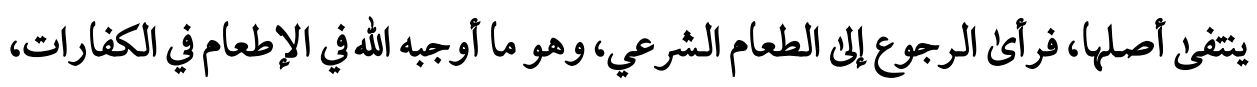

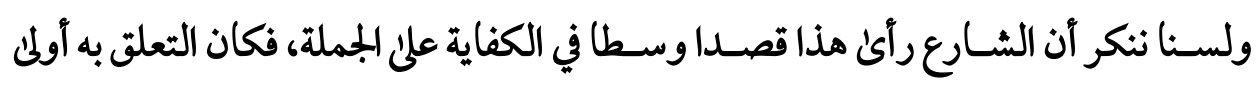
متعلق، ثم قال الشافعي: " في نص القرآن ما يدل علنم الفرق بين الموسع والمقتر " ، فإنه عز

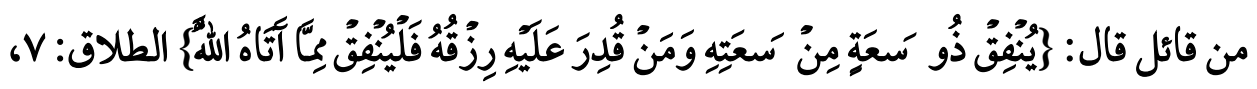

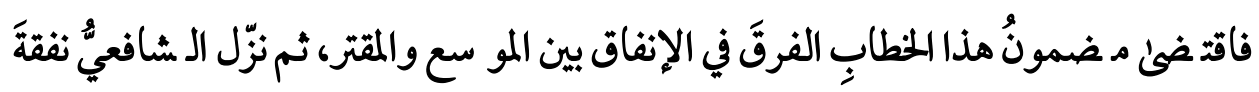

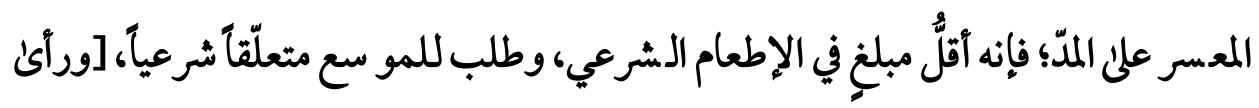

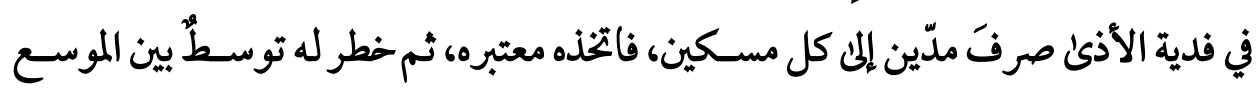

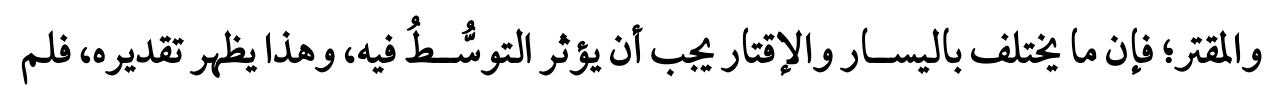

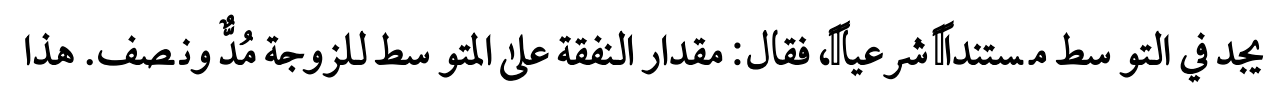

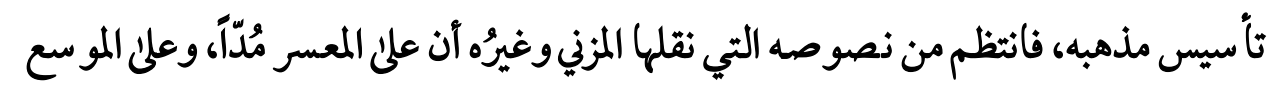
مدين، وعلى المتوسط لزوجته مد ونصف") ويقول الإمام الماوردي: في بيان الأصل الذي بنى عليه الإمام الثافعي مذهمبه في تقدير

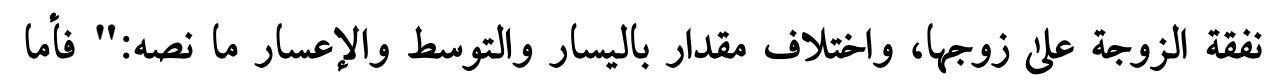

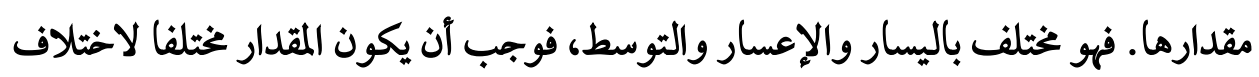

$$
\begin{aligned}
& \text { (1) (97/0)، الشافعي - الأم/2) }
\end{aligned}
$$

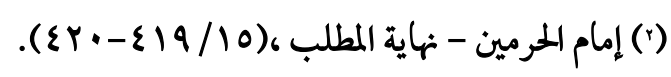


الأحوال وأن يعتبر بأصل يحمل عليه ويؤخذ المقدار منه، فكان أولى الأصول

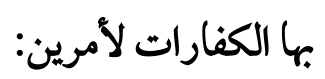

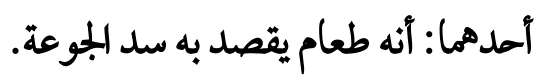
والثاني: أنه طعام يستقر ثبوته في الذمة. ثم وجدان أكثر الطعام المقدر في الكفارات فلدية الأذنى

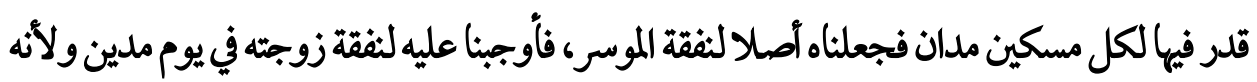

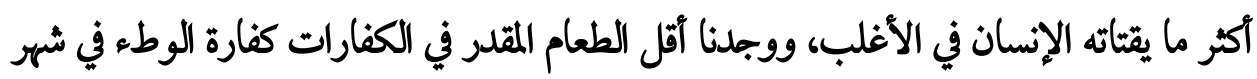

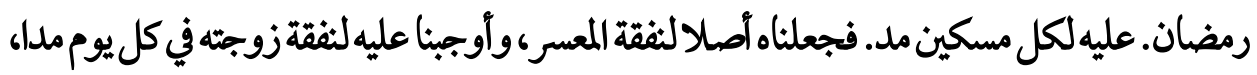
ولأثه آقل ما يقتاته الإنسان في الأغلب، ثم وجدنا المتوسط يزيد علئ حال المتتر وينقص عن حال

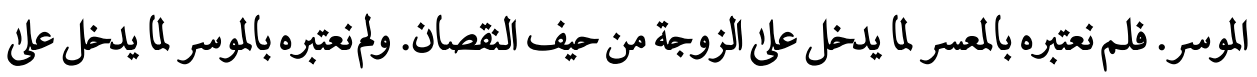

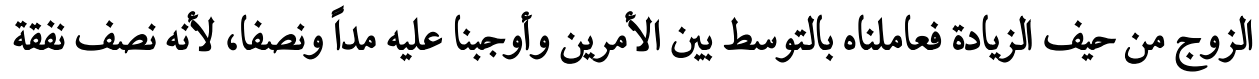
موسر ونصف نفقة معسر" (1).

وقد جاء عند السـادة الثـافعية في بيان اختلاف مقدار نفقة الزوجة بحسـبـ اختلاف

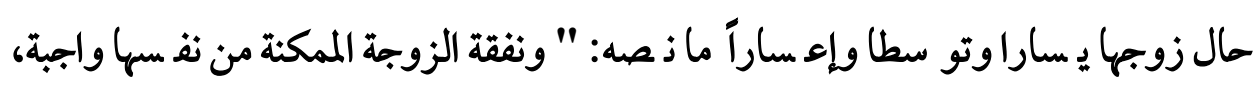

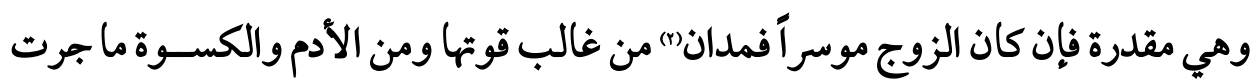

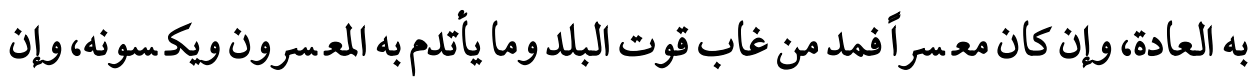

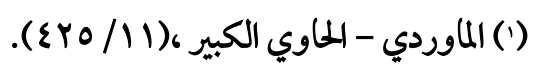

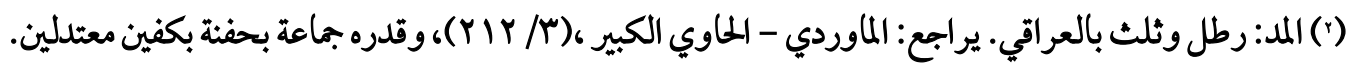

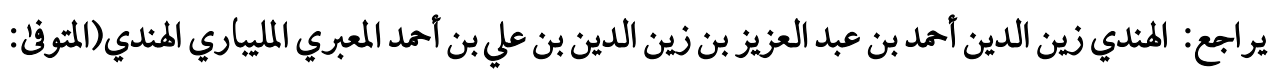

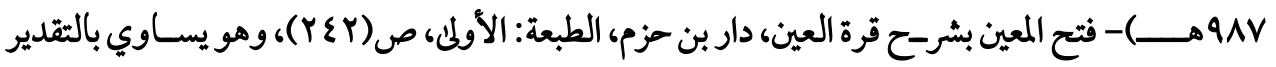

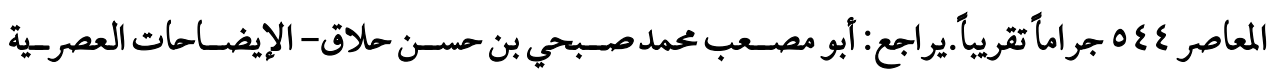

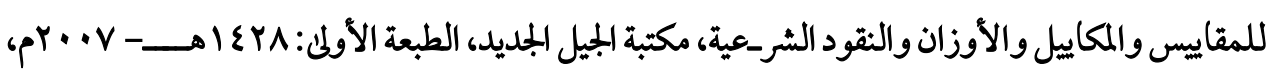


كان متوسطاً فمد ونصف ومن الأدم والكسوة الوسط" (1). والنص السابق يدل علن أن الزوج ينقسم إلى ثلاثة آقسام: القسم الأول: الزوج الموسر وهو الغني ميسور الحال. القسم الثاني: الزوج المتوسط وهو متوسط الحمال بين اليسار والإعسار. القسم الثالث: الزوج المعسر وهو الفقير المعدم. وقد بين النص السابق أن كل واحد من هذه الأقسـام له حكم يختلف عن الآخر وهو أمر طبيعي منطقي، لاختلاف حالهم من حيث اليسار والتو سط والإعسار ، ولأن في إعطاء هذه

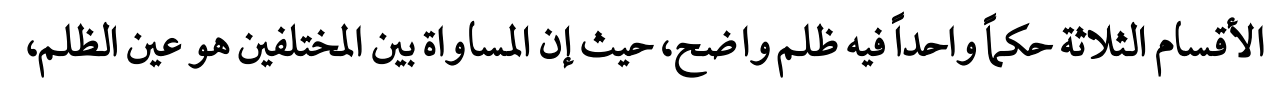
وهو ما يأباه الإسلام ويرفضه جملة وتفصيلاً. وقد بين النص السابق أن الزوج الموسر يجب عليه أن ينفق على زوجته مقدار مدان من الطعان الطعام كل يوم، ومن الأدم والكسوة ما جرت به العادة لمن هم في مثل حاله.

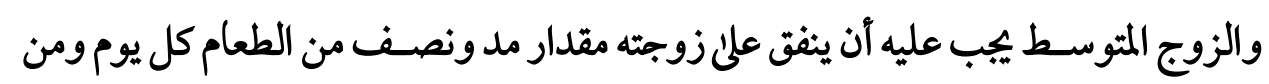
الأدم والكسوة الوسط لمن هم في مثل حاله. والزوج المعسر- يجب عليه أن ينفق على زوجته مقدار مد من الطعام كل يوم ومن الأدم والكسوة ما جرت به العادة، لمن هم في مثل حاله. وهذه و سطية وعدل وإنصاف في ضبط وإحكام التعامل بين الزوجين بها يضمن ا ستقرار الأسرة والمحافظة علئ كيانها من الانهيار، والقضاء علئ كل ما من شأنه أن يوهن العلاقة بين الزوجين، ويؤدي إلى التفكك الأسري وإثاعة الفوضى في المجتمع (().

$$
\begin{aligned}
& \text { (') أبو شجاع - متن أبي شجاع، ص(r) (1). } \\
& \text { (') من فهم الباهث. }
\end{aligned}
$$




\section{المطلب الثالثه}

\section{الوسطية في مقدار المهر}

من حسن رعاية الاسلام للمرآة واحترامه لها، آن أعطاها حقها في التملك، وفرض لها المهر،

وجعله حقاً علن الرجل لها، وليس لأبيها، ولالأقرب الناس إليها آن يأخذ شيئاً منها إلا في حال

الرضا والاختيار، وهذا المهر المفروض للمرآة، يطيب نفس المرآة ويرضيها بقوامة الرجل

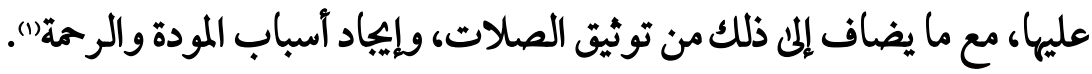

ولما كان المكم على الثي- فرع عن تصــوره، فإن معلجة هذا المطلب سـوف تشــتمل علنه

فرعين:

الفرع الأول: مفهوم المهر لغة وشرعاً.

الفرع الثاني: الوسطية في مقدار المهر.

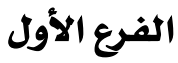 \\ مفهوم المهر لغة وشرعاً}

لما كان المهر له تعريفان، أحدهما في اللغة، والآخر في الشرع، فإن معالجة هذا الفرع سوف تشتمل

على مسألثين:

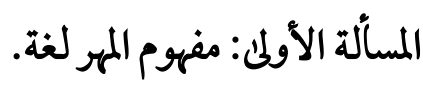

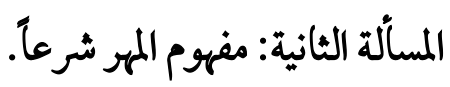

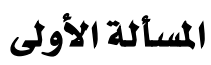

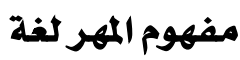

المهر لغة: صداق المرآة تقول: مهرت المرآة مهراً إذا أعطيتها المهر، أو قطعته لما، فهي

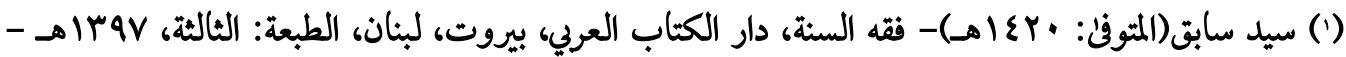

(19VV 
مهورة، وتقول أمهرت المرآة مهراً بالألف إذا زوجتها من رجل علن مهر، فهي مهرة").

\author{
المسألة الثانية \\ مفهوم المهر ثرعاً \\ عرف فقهاء الشافعية المهر بأنه:" هو اسم للمال الواجب للمرآة على الرجل بالنكاح أو \\ الوط\&،" (r).
}

(') الفيومي - المصباح المنير في غريب الشرح الكبير ، كتاب الميم، مادة:(م هـر)،(Y / (1) ).

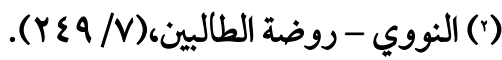




\section{الفرعالثاني

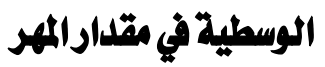

اتفت فقهاء الشافعية علئ استحباب الوسطية في مقدار المهر بين الإسراف والتقتير(1)، وأن المهر ليس لأقله وأكثره حد مقدر، فهو معتبر بما تراضى عليه الزوجان من قليل أوكثيريه")

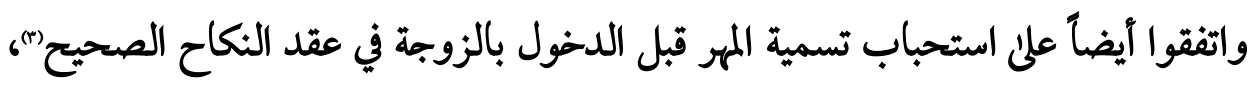
وعلئ وجوب المهر علئ الزوج لزوجته، بمقتضى عقد النكاح الصحيح (i).

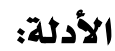

أ- أدلة استحباب الوسطية في مقدار المهر بين الإسراف والثقتير، وأنه ليس لأقله وأكثره حد

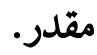
استدل فقهاء الشافعية على استحباب الوسطية في مقدار المهر بين الإسراف والتقتير، وأنه ليس لأقله وأكثره حد مقدر، بالكتاب الكريم ، والسنة النبوية المطهرة، والمعقول.

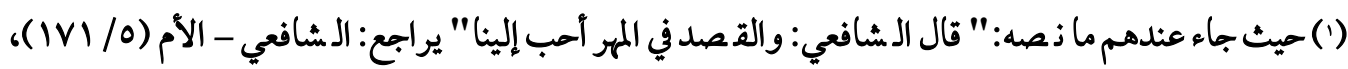

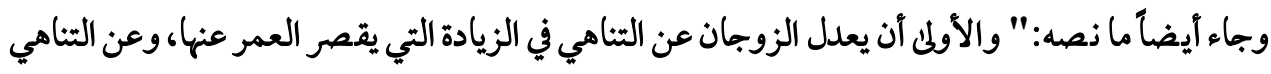

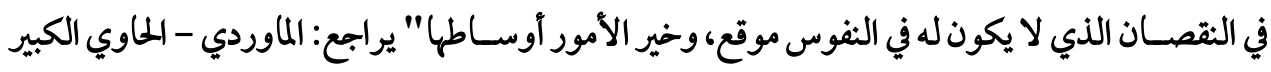

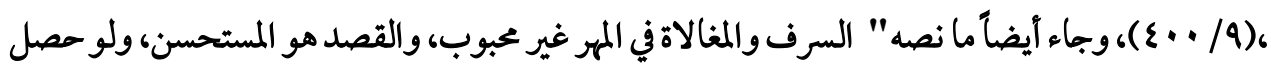

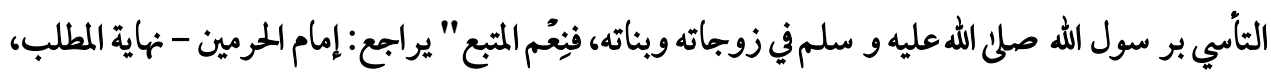
. (9//Y)

(") حيث جاء ما نصه:" ثبت أن أقل المهر وأكثره غير مقدر، فهو معتبر با تراضى عليه الزوجان من قليل وكثير"

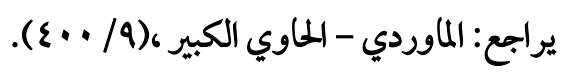

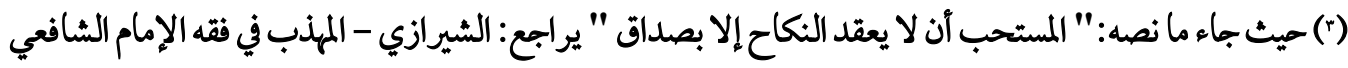

$$
\text { ( }(\varepsilon T / Y) \text { ) }
$$

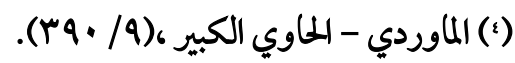




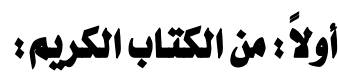

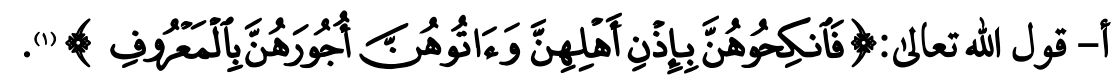

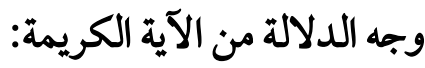

في هذه الآية الكريمة أمر اللهعزوجل الأزواج أن يعطو أزوابهن مهورهن بالمعروف علئما

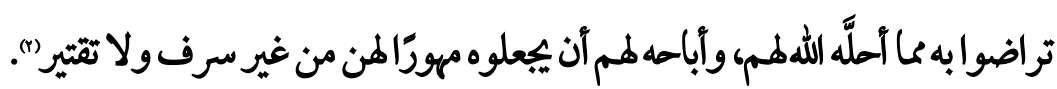

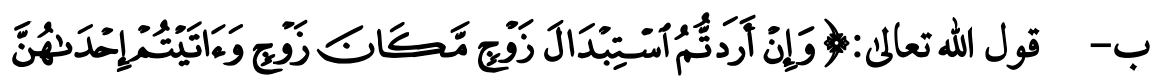

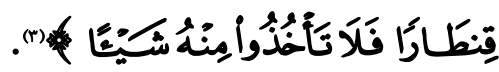

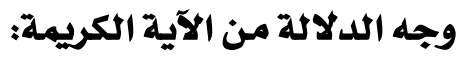

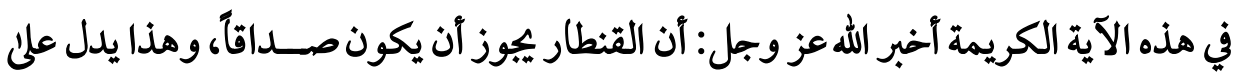

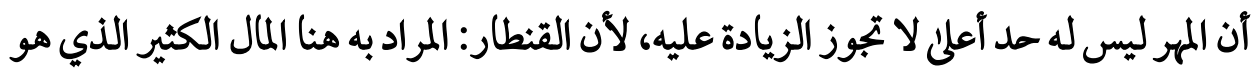
أقصىـــ ما يتصــور من مهر يدفعه الرجل للمرآة (i)، والقنطار هنا فيه مبالغة في مقدار المال

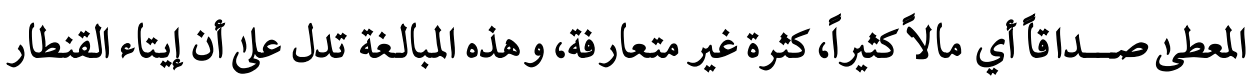
مباح شرعاًّا.

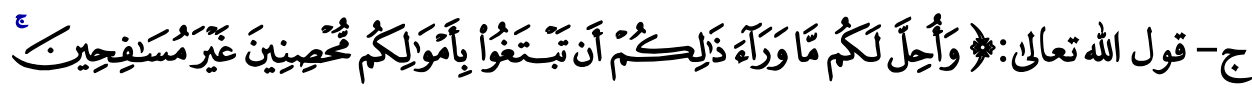

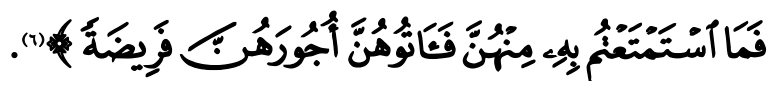

$$
\begin{aligned}
& \text { (') سورة النساء من الآية رقم(Y)( (1). }
\end{aligned}
$$

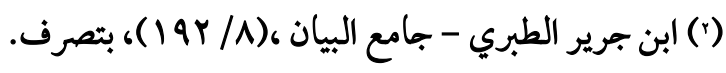

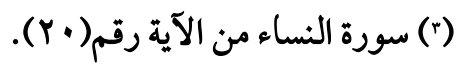

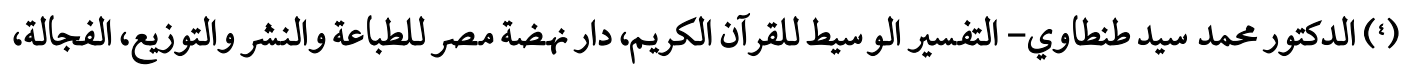

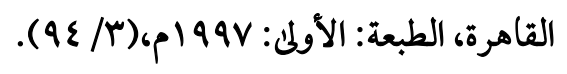

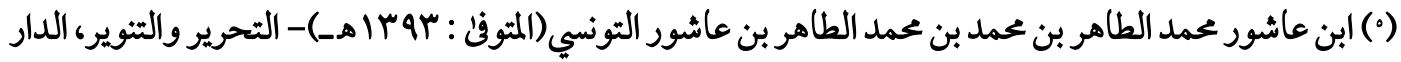

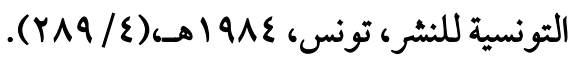

$$
\begin{aligned}
& \text { (() سورة النساء من الآية رقم(צ'). }
\end{aligned}
$$


وجه الدلالة من الآية الكريمة:

تدل هذه الآية الكريمة على أن المهر في الشريعة الإسلامية هبة وعطية، وليس له قدر محدّد، لأن قول الله تعالى " بأموالكم" لفظ عام يفيد القليل والكثير ، ولأن الناس يختلفون في الغنى والفقر، ويتفاوتون في السعة وال ضيق، فتركت الشريعة الإ سلامية التحديد، ليعطي كل واحد علئ قدر طاقته، وحسب حالته ، وهذا يدل على وسطية الأحكام الشرعية وعدالتها، والمتمثل في رعايتها اختلاف أحوال الناس فقراً وغناً وسعة وضيقاً). ثانياً: من السنة النبوية المطهرة:

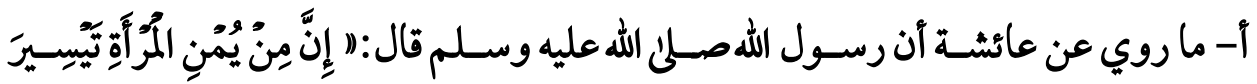

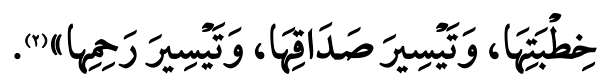
وجه الدلالة من الحديث الشريف: يدل هذا الحديث النبوي الشر-يف علئ اسـتحباب التيسـيـ في كل ما يتعلق بشـــون الأسرة المسلمة ب صفة عامة، وفي المهر بـصفة خا صة تي سيراً و سطاً معتدلاً، بين الإفراط والتفريط يضــمن للزوجة حقها ومكانتها، ويشـعر الزوج بقيمة الحياة الزوجية، وعدم التقصـير في الواجبات الملقاة على عاتقه، بمقتضئ-عقد الزواج الصسحيح ، حيث بين الحديث النبوي الشريف أن من بركة المرآة سهولة سؤال الخاطب أولياءها نكاحها، واجابتهم بسهولة ويسر

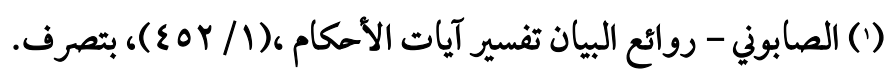

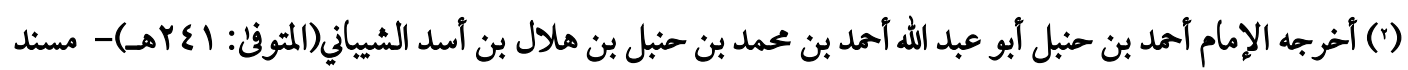

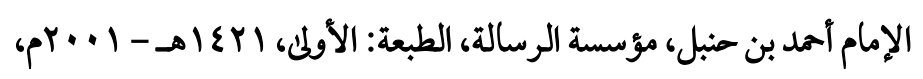

تحقيق: شعيب الأرنووط وغيره، مسند النساء، مسند الصديقة عائشة بنت الصديق رضي اللهنها،

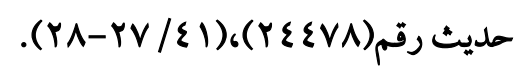

وجاء عن هذا المديث ما نصـه:" رواه أحمد، وفيه أسـامة بن زيد بن أسـلمه، وهو ضـعيف، وقد وثق، وبقية رجاله

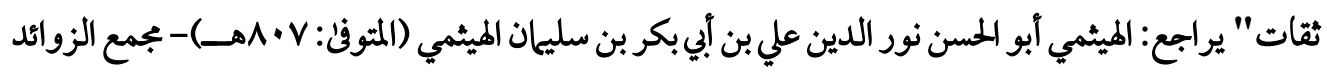

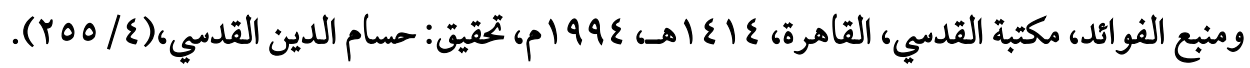


من غير توقف ولا اشـتراط، وعدم التشـديد في تكثير المهر ووجدانه بيد الخاطب من غير كد زائد عن المعتاد في تحصيله وتيسير رحمها، بأن تكون ولوداً سريعة الحمل كثيرة النسل "(1).

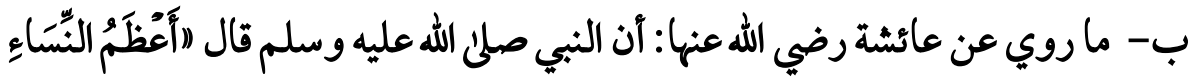

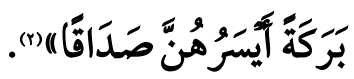

\section{وجه الللالة من الحلديث الشريف:}

يدل هذا الحديث النبوي الشريف على آن التيسير في مقدار المهر دليل علن خيرية المرآة ويمنها وبركتها، فيكون ذلك من قبيل الفأل الحسن (r) ويدل أيضاً على استحباب التيسير في مقدار المهر، وأن التيسير فيه من أسباب حلول البركة والسعادة على بيت الزوجية، إذا خلصت النوايا، لأن اليسر داع إلى الرفق، والله رفيق يحب الرفق في الأمر كله (s).

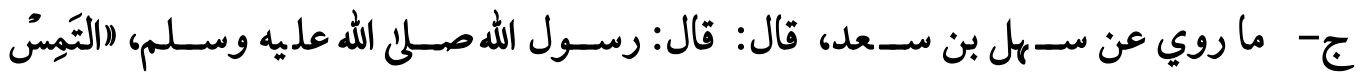

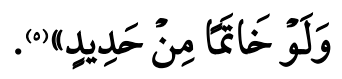

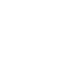

(') المناوي زين الدين محمد المدعو بعبد الرؤوف بن تاج العارفين بن علي بن زين العابدين الحدادي ثم المناوي القاهري

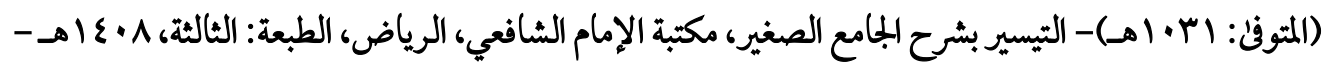

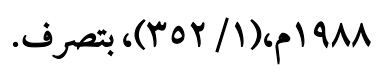

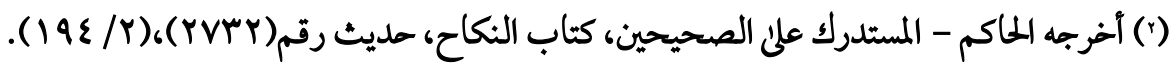
وقال الحاكم عن هذا الحديث ما نصـه:" هذا حديث صـحيح علئ شرط مسـلم، ولميخرجاه" يراجع: الحاكم-

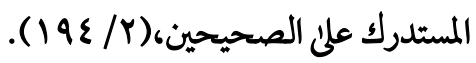
(r) المناوي زين الدين محمد المدعو بعبد الرؤوف بن تاج العارفين بن علي بن زين العابدين الحدادي ثم المناوي القاهري

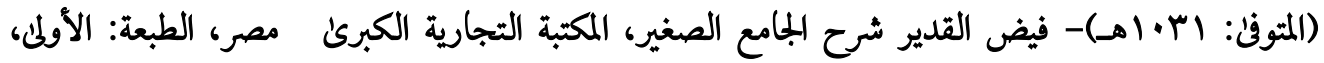

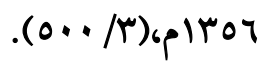

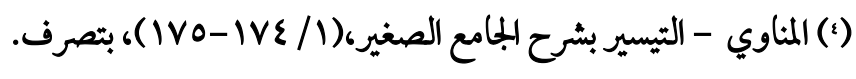

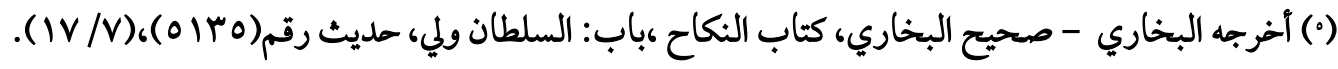




\section{وجه الدلالة من الحديث الشريف:}

يدل هذا الحديث النبوي الشُريف على آن آقل المهر ليس له حد معين يقف عنده لا يجوز النقصان عنه، وهذا يدل على مدئ وسـطية الأحكام الشر-عية وعدالتها، لأن في التحديد تضــييقاً على الناس وفي تركه توسعة عليهم ورفقاً بهم، والتوسعة على الناس والرفق بهم مقصد من أعظم مقاصد الشريعة الإسلامية الغراء".

د- ما روي عن أنس بن مالك، أن النبي صـلنى الله عليه وسـلم رأى على عبد الرحمن بن عوف

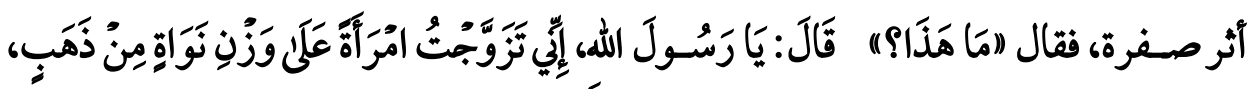

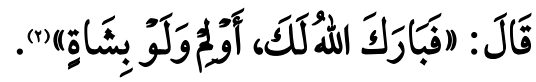

\section{وجه الدلالة من الحديث الشريف:}

يل هذا الحديث النبوي الشريف علنياستحباب تقليل الصداق، لأن سيدناعبد الرمنبن عوف كانمن مياسير الصحابة،

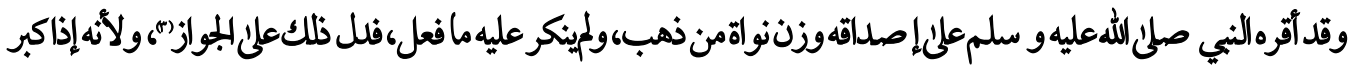

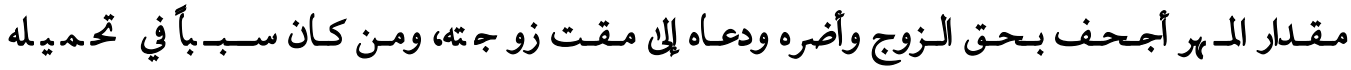
مالايطيق). ثالثاً: من المعقول: وذلك من ثلاثة وجوه:

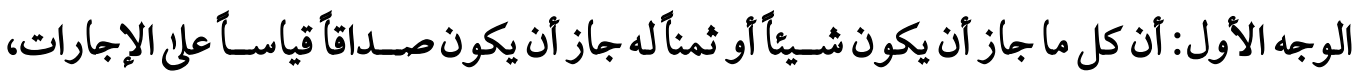
لأنها منافع طارئة على أعيان باقية، وآشبه الأشياء بالإجارات الاستمتاع بالبضع (م).

$$
\text { (') (الخطابي - معالم السنن، (Y)/ (Y) )، بتصرف. }
$$

(') أخرجه مسلم - صحيح مسلم، كتاب الحجه، باب الصداق، وجواز كونه تعليم قرآن، وخاتم حديد، وغير ذلك من

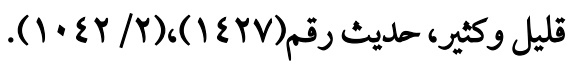

$$
\begin{aligned}
& \text { (r) ابن حجر العسقلاني - فتح الباري شرح صحيح البخاري،(4/ جrY)، بتصرف. } \\
& \text { (؛) الشيرازي - المذب في فقه الإمام الشافعي ،(Y/ ع ع)، بتصرف. }
\end{aligned}
$$

(•) ابن عبد البر أبو عمر يوسف بن عبد اللهبن محمد بن عبد البر بن عاصـم النمري القرطبي (المتوفن: سآعهــ)- التمهيد

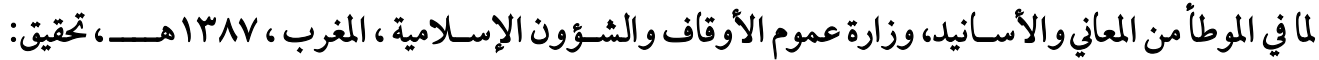


الوجه الثاني: أن مقدار المهر ليس لأقله ولا لأكثره حد مقدر، إذ الناس يختلفون في الغنى والفقر، ويتفاوتون في السعة والضيق، ولكل جهة عاداتها وتقاليدها، فتركت الشريعة الإسلامية

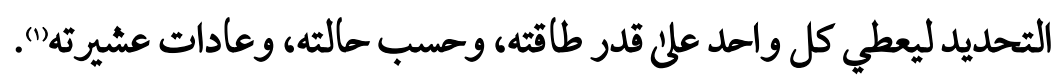

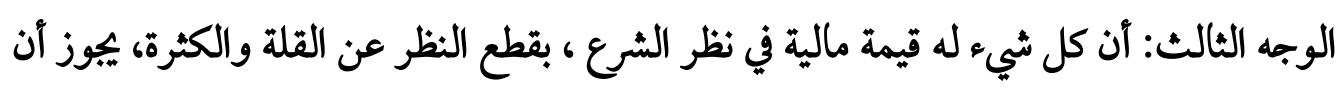

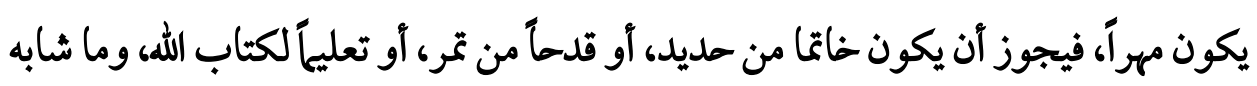
ذلك، إذا تراضى عليه المتعاقدان").

بـ أدلة استحباب تسمية المهر قبل الدخول بالزوجة في عقد النكاح الصحيح. استدل فقهاء الثافعية على استحباب تسمية المهر قبل الدخول بالزوجة في عقد النكاح الصحاب الصحيح. بالمعقول: وذلك من وجهين: الوجه الأول: أن الإسـالام حريص على استـقرار الحياة الزوجية، وبقاء المودة والرحمة بين

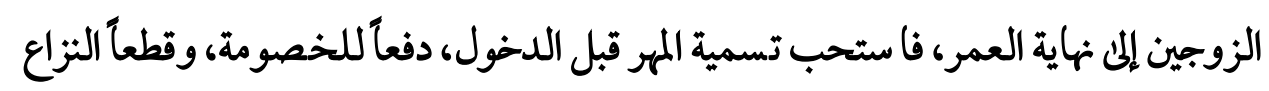

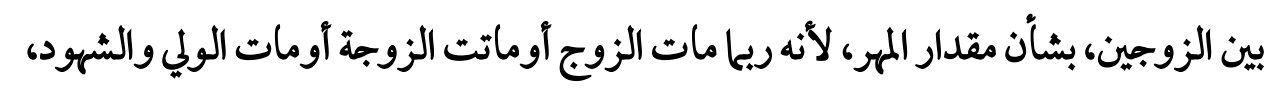

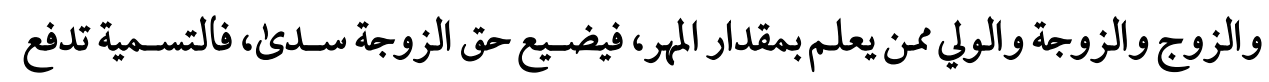

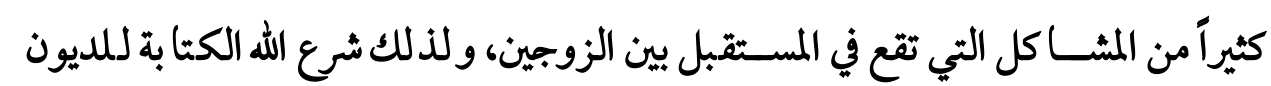
والحقوق؛ من أجل أن تصل الحقوق إلى أصحابها (r).

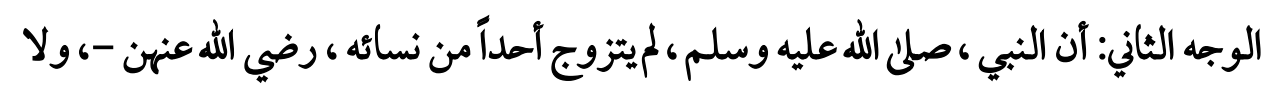

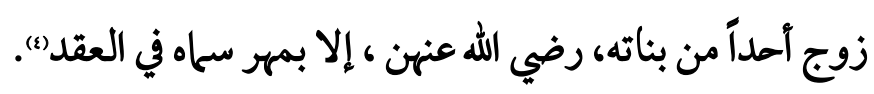

مصطفى بن أهمد العلوي وغيره، (Y/ (1) ).

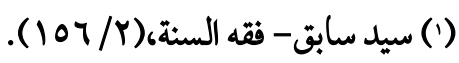

$$
\begin{aligned}
& \text { (') (') المرجع السابق نفس الصفحة، بتصرف. }
\end{aligned}
$$

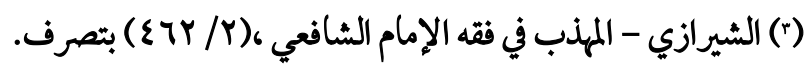

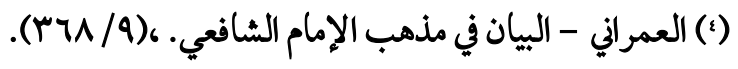


ج- أدلة وجوب المهر على الزوج لزوجته، بمقتضى عقد النكاح الصحيح. ا ستدل فقهاء الشافعية على وجوب المهر على الزوج لزوجته، بمقتضئ عقد النكاح الصحيح، بالكتاب الكريم، والسنة النبوية المطهرة، والإجماع. أولاً: من الكتاب الكريي:

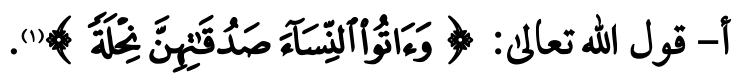
وجه الدلالة من الآية الكريمة: تدل هذه الآية الكريمة علئ وجوب المهر على الرجل للمرآة في النكاح الصـحيح، لآن

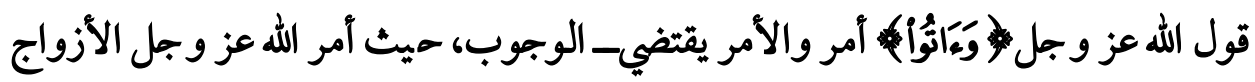
بإعطاء النسـاء مهورهن فريضــة من الله عز وجل، ، فدل هذا على وجوب المهر للمرأة، وهو أمر مجمع عليه ولا خلاف فيه (r).

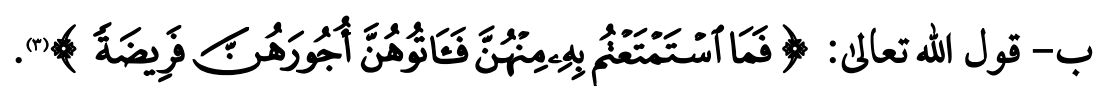

\section{وجه الدلالة من الآية الكريمة:}

تدل هذه الآية الكريمة على وجوب المهر للمرأة بالزواج، حيث أمر الله الآزواج بإعطاء زوجاتهن أجورهن، أي مهورهن، ثم تأكد هذا الوجوب بقوله(فريضــة) أي باعتبار آن ذلك فرضاً فرضه الله عز وجل على الزوج لزوجته، بمقتضي عقد الزواج، وليس تفضلاً من الزوج على زوجته()، ومن ثم فإذا تزوج الرجل المرأة، ثم نكحها مرة واحدة، فقد وجب صـــداقها

$$
\begin{aligned}
& \text { (') (') سورة النساء من الآية رقم(ع). }
\end{aligned}
$$

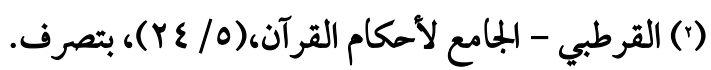

$$
\begin{aligned}
& \text { (r) سورة النساء من الآية رقم(ع Y). } \\
& \text { (\&) الإمام الشافعي - تفسير الإمام الشافعي، (OVV )، بتصرف. }
\end{aligned}
$$


كله، لأن الاستمتاع في الآية الكريمة معناه النكاح، والأجر معناه المهر (1).

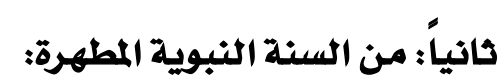

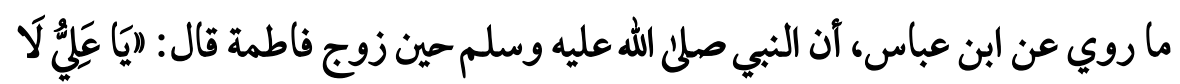

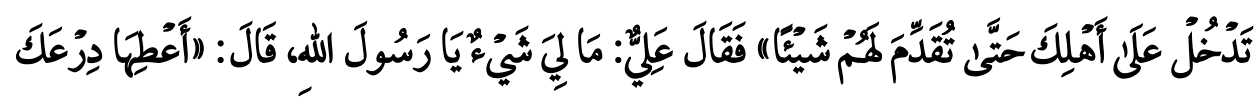

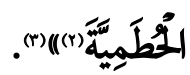

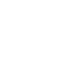

(') ابن المنذر أبو بكر محمد بن إبراهيم بن المنذر النيسابوري(المتوفن: 19 آهـ)- تفسير القرآن ، دار المآثر، المدينة النبوية،

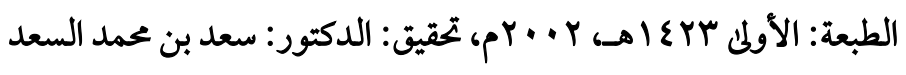

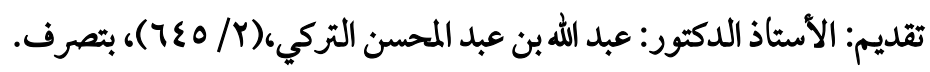

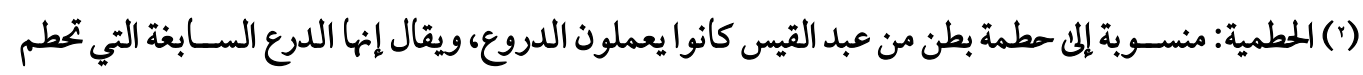

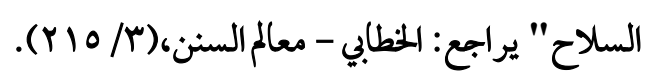

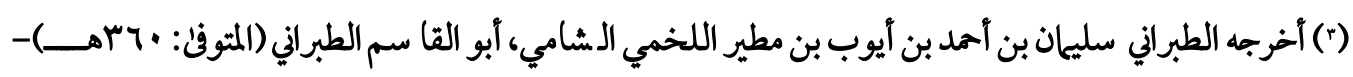

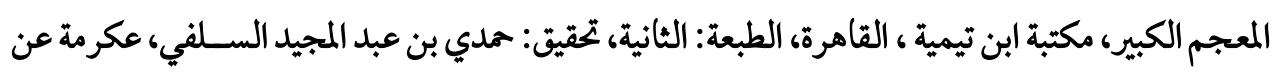

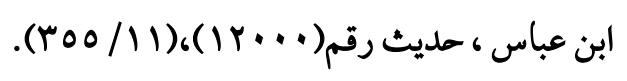

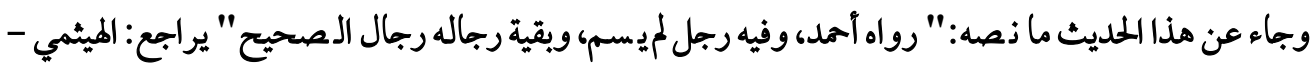

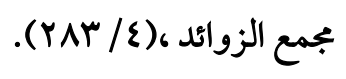




\section{وجه الدلاكلة من الحديث النبوي الشريف:}

يدل هذا الحديث النبوي الشر-يف علئ وجوب المهر علئ الزوج لزوجته، بمقتضىنـعقد الزواج، ويدل أيضـــاُ على أنه يجب على الزوج تقديم شيء من المهر للزوجة قبل الدخول بها ولو كان شـيئاً قليلاً جبراً لحاطرها، وهو المعروف عند الناس كافة")، كا أنه يدل على جواز الامتناع من تسليم الولي الزوجة لزوجها ما لم تقبض مهرها (r). ثالثاً: من الإجماع: فقد أجمعت الأمة على أن صداع، مناق الزوجات مستحق (r).

\section{تعقيب وتعليق:}

إن التيسير في مقدار المهر تيسيراً سطاً معتدلاًام يقتضيه الصالح العالح العام، وتقتضيه المصلحة العامة، حيث إن في ذلك م صلحة كبيرة للزوجين، وللمجتمع بأسره، فكم من ذساء جل سن بلا أزواج، وكم من شـباب، قعدوا بلا زوجات، بسـبب المغالاة في المهور ، التي خرجت إلى

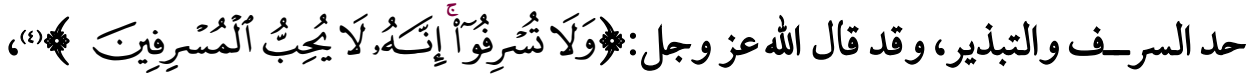

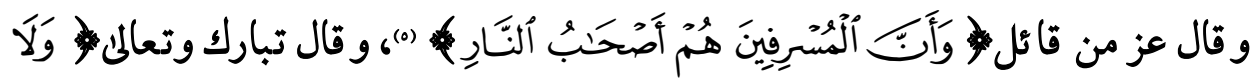

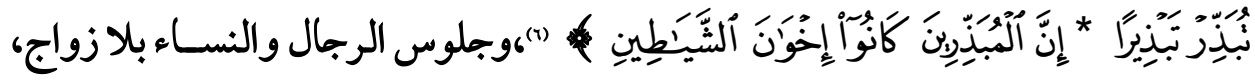
يحملهم على ارتكاب الفواحش والمنكرات ما ظهر منها و ما بطن، و قد قال اللهز و جل

$$
\begin{aligned}
& \text { (') الصنعاني - سبل السلام ، (Y) (Y)، بتصرف. } \\
& \text { (') الشوكاني - نيل الأوطار،(T/T (Y). }
\end{aligned}
$$

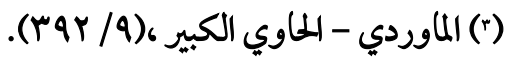

$$
\begin{aligned}
& \text { () سورة الأنعام من الآية رقم(1) (1). } \\
& \text { (•) سورة غافر من الآية رقم(r) ). } \\
& \text { (?) سورة الإسراء من الآيتين رقم(Y (YV-Y). }
\end{aligned}
$$




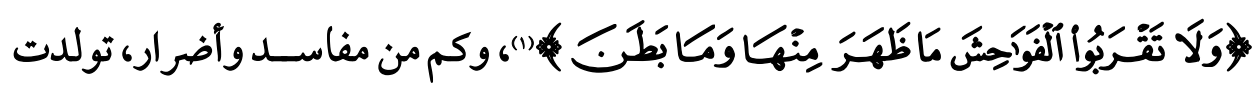

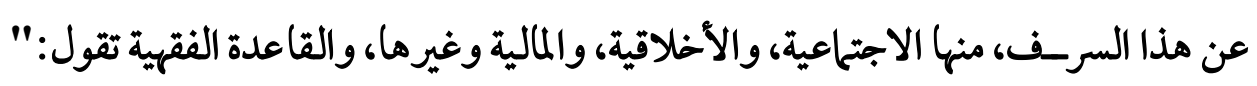

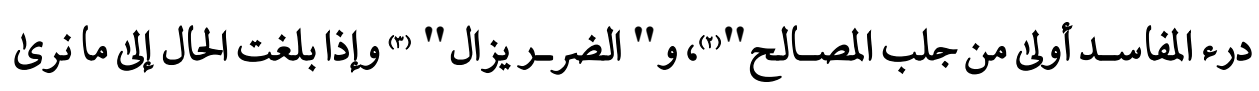
وذ سمع، فالذي نعتقد أنه لابد من تدخل ولي الأمر في هذه الم سألة، لحل هذه الأزمة، وإلزام

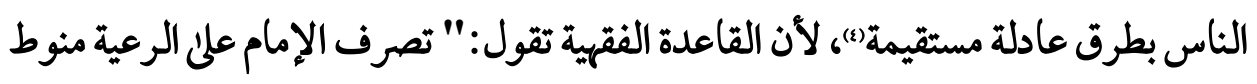

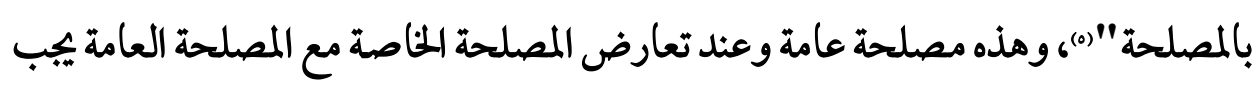
تقديم المصلحة العامة على الخاصة).

$$
\begin{aligned}
& \text { (') سورة الأنعام من الآية رقم(10101). }
\end{aligned}
$$

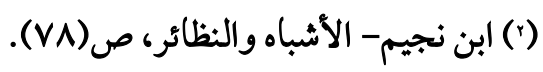

$$
\begin{aligned}
& \text { (r) السبكي - الأشباه والنظائر، (1/ (ع) ). }
\end{aligned}
$$

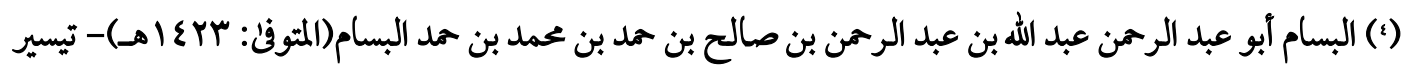

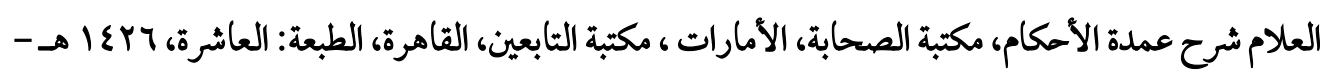

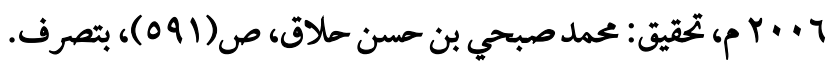

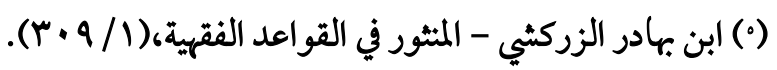

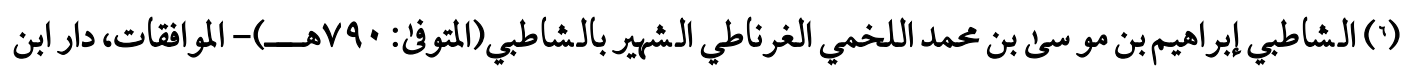

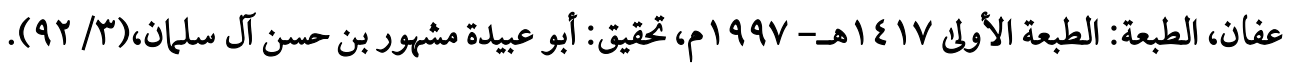




\section{المبهث الورابع}

\section{ثماذج تطبيقية من الوبطيلة في ققه الحدود}

لما كان الحكم علني الشيء فرع عن تصوره، فإن معالجة هذا المبحث، سوف تشتمل على

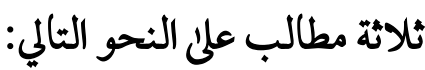

$$
\text { المطلب الأول: مفهوم الحد لغة وشرَاً. }
$$

المطلب الثاني: الوسطية في جلد الزاني غير المحصن، والقاذف، وشارب الخمر. المطلب الثالث: الوسطية في رجم الزاني المحصن، والزانية المحصنة.

\section{المطاب الأول}

مفهوم الحلد لفة وشئرماً

لما كان الحد له تعريفان أحدهما في اللغة، والآخر في الشرع، فإن معالجة هذا المطلب

$$
\begin{aligned}
& \text { سوف تشتمل على فرعين: } \\
& \text { الفرع الأول: مفهوم الحد لغة. } \\
& \text { الفرع الثاني: مفهوم الحد شرعاً. }
\end{aligned}
$$

الفرع الأول

\section{مفهوم الحد لغة}

اللحد لغة: المنع والحاجز بين الشيئين".

$$
\text { مفهوم الحد ثرعاً }
$$

عرف فقهاء الشافعية اللحد شرعاًَأنه:" عقوبة مقدرة وجبت زجراً اعن ارتكاب ما يوجبه" (().

(') ابن فارس أحمد بن فارس بن زكرياء القزويني الرازي، أبو الحسين(المتوفن: 90 بهــ)- معجم مقاييس اللغة، دار

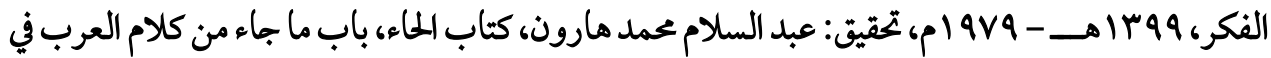

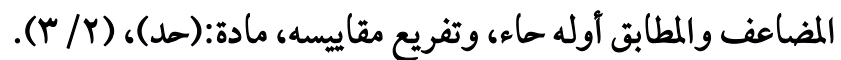

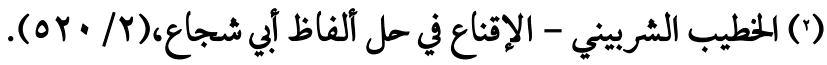




$$
\text { المطلب الثناني }
$$

الوسطية هِ جلد (1) الزاني المحصن، والقاذف، وشمارب الخمر

اتفق فقهاء الـ شافعية على أن الزاني غير المح صن حده الملد مائة جلدة، وتغريب عام (r)،

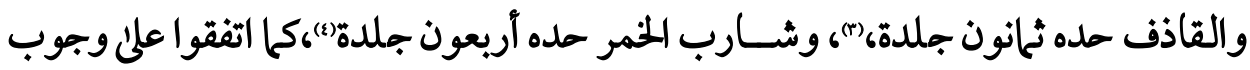

الوسطية في حجم السوط(م) الذي يضرب به اللماني (1)، وصفته(v) ، وكيفية الضرب به().

\section{الأدلة:}

اسـتلل فقهاء ال شافعية على وجوب الو سطية في حجم ال سوط الذي يـ ضرب به الباني، و صفته، وكيفية الضرب به، بالكتاب الكريم، والسنة النبوية المطهرة، والأثر الشريف، والمعقول.

(') الجلد: هو الضرب بالمجلد بكسر الميم وهو السوط: يراجع: الفيومي - المصباح المنير في غريب الشرح الكبير،

$$
\text { كتاب الجيم، الجيم مع اللام وما يثلنها، مادة:(جلد)،(1/ ع • (1). }
$$

(r) حيث جاء ما نصه:" وغير المحصن حده مائة جلدةًأ وتغريب عامًألما مسافة القصر " يراجع: أبو شجاع - متن

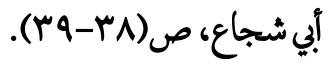

(r) حيث جاء ما نصه:" قال الشافعي : رحمه الله، إذا قذف البالغ حراً بالغاً مسلماً آو حرة بالغة مسلمة حد ثُانين "

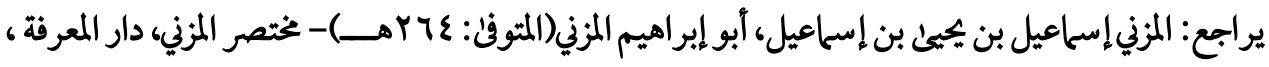

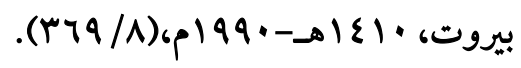

(؛) حيث جاء ما نصه:" ومن شرب خمرآ آو شراباً مسكراً حد أريعين" يراجع: اللصني - كفاية الأخيار، ص(1) ).

$$
\text { ( ) السوط: سيور تلف وتلوئ. يراجع: الرملي - نهاية المحتاج ، IV /N). }
$$

(") حيث جاء ما نصه:"وهو بسوط معتدل اللحجم بين القضيب والعصا" يرجع: النووي - روضة الطالين،

$$
\text { (IVY/l.) }
$$

(vيث جاء ما نصه:" فأما صفة السوط الذي تقام به الحدود فهو بين السوطين لا جديد فيتلف، ولا خلق لا يؤلم"

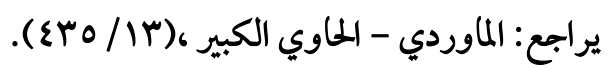

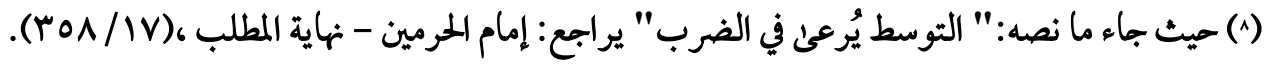
وجاء أيضـاً ما نصـه:" وأما رفع اليد فلا يرفعه فوق الرأس فيعظم الألمه ولا يكتفي بالرفع اليســــ فلا يؤلمه بل

$$
\text { يراعي التوسط" يراجع: أبو حامد الغزالي - الوسيط في المذهب،(7/ 1) (0). }
$$


أولأ: من الكتاب الكريم:

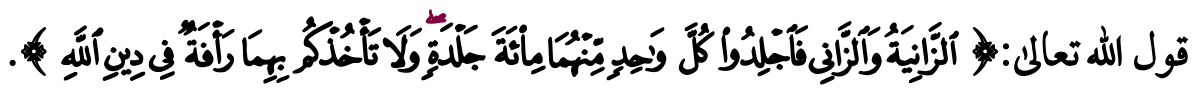

\section{وجه الدلالة من الآية الكريمة:}

في هذه الآية الكريمة أمر الله عز وجل بجلد الزاني غير المحصــن مائة جلدة ونهل عن التخفيف فيه تخفيفاً لا يحقق الحكمة من مشرــوعيته، أو تعطيله بالكلية، ويفهم من ذلك وجوب مراعاة الوســية والاعتدال في حجم السـوط الذي يجلد به الزاني غير المحصـن، و صفته، وكيفية الضرب به(")،لأنه لميرد شيء في تخفيف الضرب ولا تثقيله، فوجب الو سط (المعتدل (r) - (2)

\section{ثانياً: من السنة النبوية المطهرة:}

ما روي عن زيد بن أسلم، أن رجلاًا اعترف على نفسه بالزنا على عهد رسول اللهصلئ الله

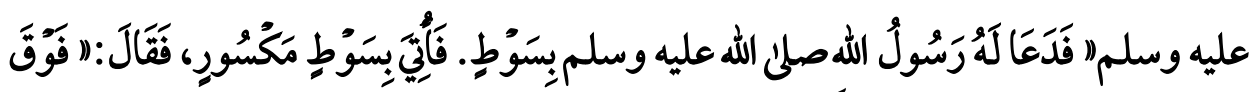

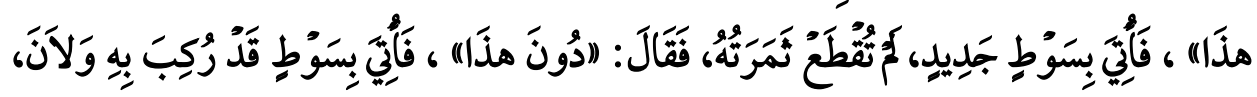

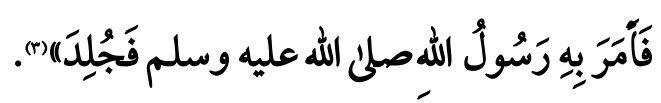
وجه الدلالة من الحديث الشريف: يدل هذا الحديث النبوي الشريف على وجوب الوايث الوسطية في جلد الزاني غير المحصن بأن

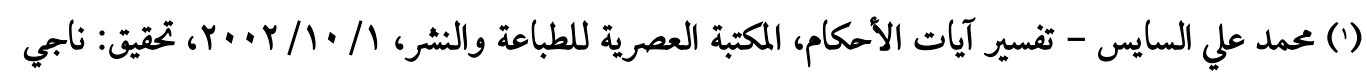

$$
\begin{aligned}
& \text { سويدان،(1) إن)، بتصرف. }
\end{aligned}
$$

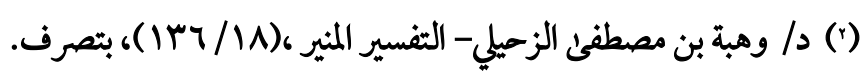

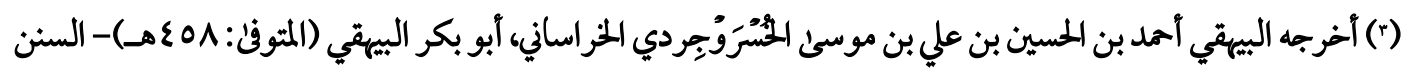

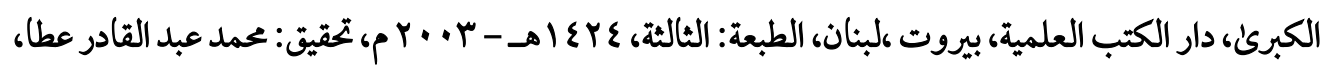

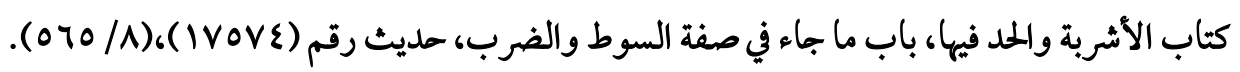

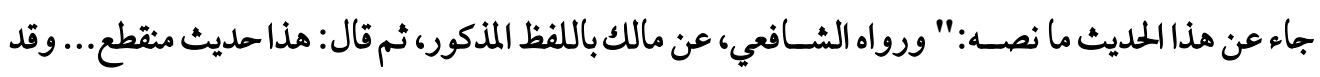

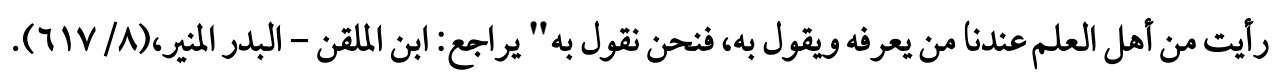


يكون السوط المجلود به وسطاً معتدلاً بين اليبوسة والليونة)..

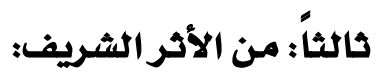

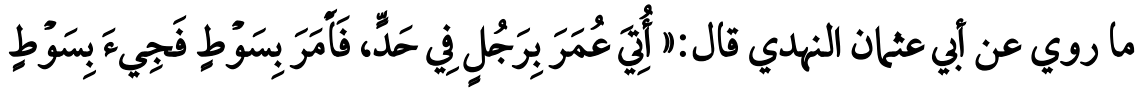

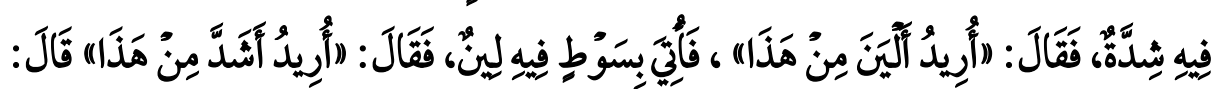

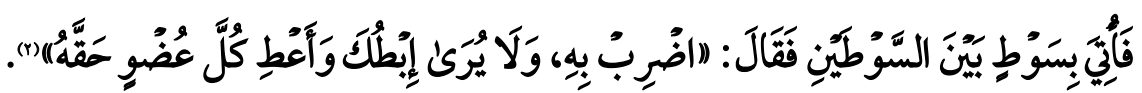
وجه الدلالة من الأثر الشريف:

يدل هذا الأثر الشريف علئوجوب الوسطية في السوط وفي الضرب، مع تفريق الضرب

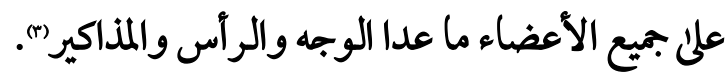

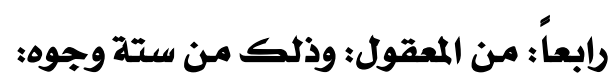

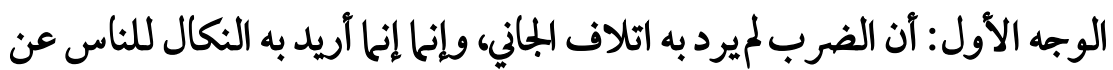
المحارم، والتزام الوسطية في معاقبة الجلني يحقق هذا المدف النبيل للشريعة الإسلامية بسهولة ويسر).

الوجه الثاني: أن إيلام الجاني لا بد منه في إقامة الحد، مع بناء الأمر على تجريد القصد إلى الثا

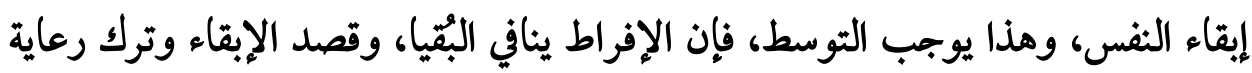

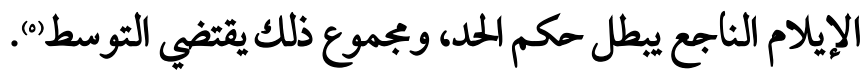

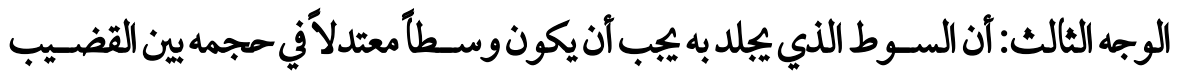

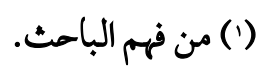

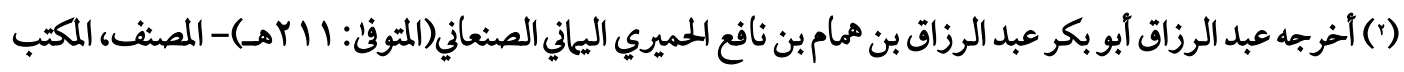

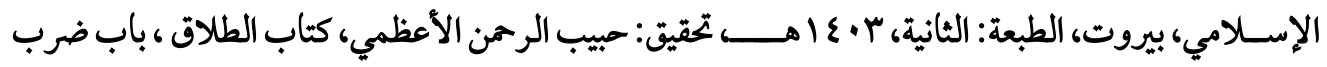

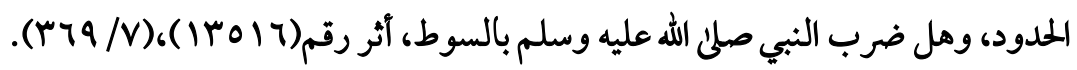

$$
\begin{aligned}
& \text { (") (") من فهم الباحث. }
\end{aligned}
$$

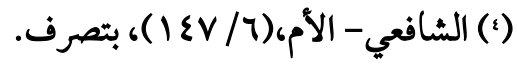

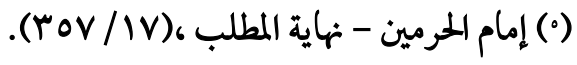


والعصاووسطاً معتدلاًين الرطوية واليوسة، لأن السوط الرطب يشق البلدلثقله، والسوط اليابس لا يؤلملخته ، فيفوت الغرض المقصود من البلد، فيجب التوسط بينها").

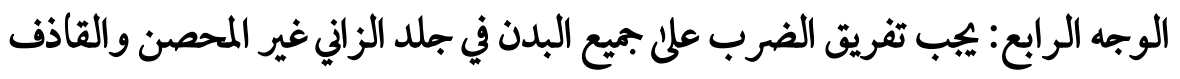
وشارب الخمر، لأن الضرب في مكان واحد يؤدي إلى الملاك المان.

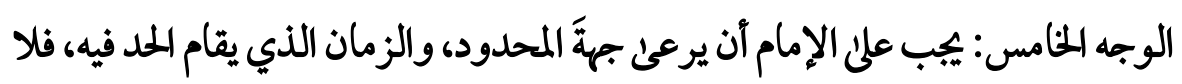

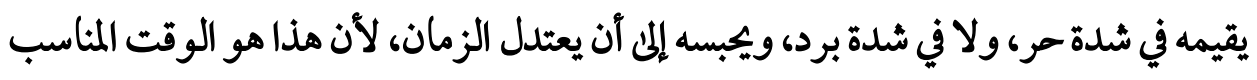

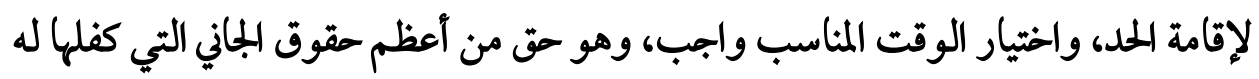
الإسلام الحنيف"). الوجه السادس: يجب الضمان إذا وقع الضرب بخشبة فوق الوسط آو فرض تحامل

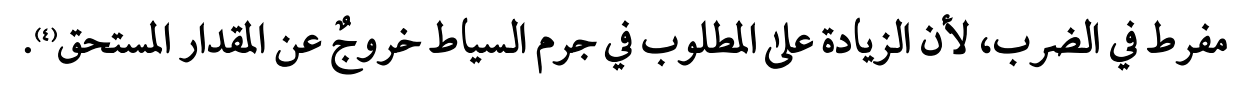

$$
\begin{aligned}
& \text { (') الشيخ زكريا الأنصاري- أسنى المطالب،(ع / ا (1)، بتصرف. }
\end{aligned}
$$

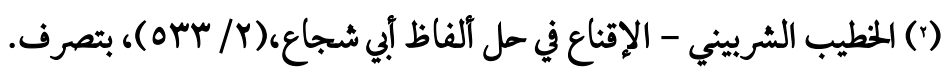

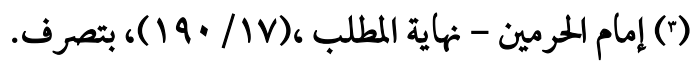

$$
\begin{aligned}
& \text { () المرجع السابق ، (Y०q/NV)، بتصرف. }
\end{aligned}
$$




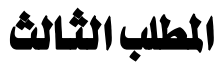

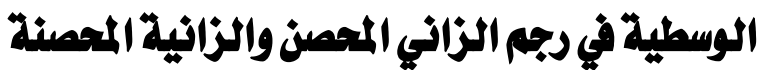

لملا كان الحكم علئ الشيء فرع عن تصوره، فإن معلجة هذا المطلب سوف تشتمل على ثلاثة فروع:

$$
\begin{aligned}
& \text { الفرع الأول: حقيقة الرجم لغة وشرعاً. } \\
& \text { الفرع الثاني: الوسطية في رجم الزاني المحصن. } \\
& \text { الفرع الثالث: الوسطية في رجم الزانية المحصنة. } \\
& \text { الفرع الأول } \\
& \text { حقيقة الرجم لغة وثرعاً }
\end{aligned}
$$

لما كان الرجم له معنيان أحدهما في اللغة والآخر في الشرع، فإن معالجة هذا الفرع سوف

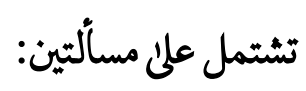

المسألة الأولن: حقيقة الرجم لغة.

المسألة الثانية: حقيقة الرجم شرعاً.

\author{
المسألة الأولى \\ حقيقة الرجم لغة \\ الرجم لغة: القتل، وأصله الرمي بالحجارة"(1). \\ المسالة الثانية \\ حقيقة الرجم شرعاً \\ حقيقة الرجم في عرف فقهاء الشافعية هي أن يضرب اللجاني بالحجارة حتى الموت"().

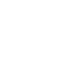

(') الجوهري أبو نصر إسماعيل بن ماد الجوهري الفارابي (المتوفن: به بهــ)- الصحاح تاج اللغة وصحاح العربية،

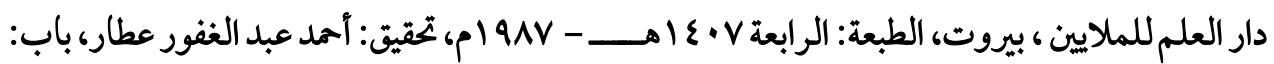

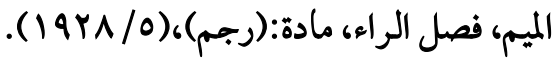

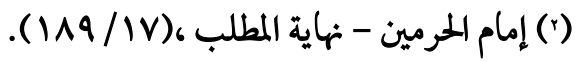




\section{الفرع الثاني \\ الوسطية ِِِ رجم الزاني المحصن}

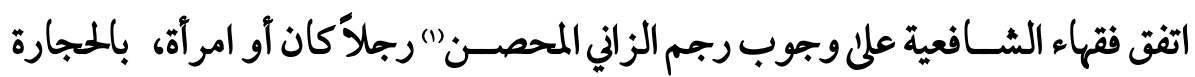

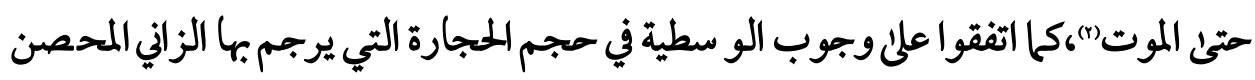
رجلاً كان أو امرأة (7)، والوسطية في المسافة بين الراجم من المرجوم (8).

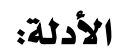

$$
\text { أ- أدلة وجوب رجم الزاني المحصن بالحجارة حتى الموت. }
$$

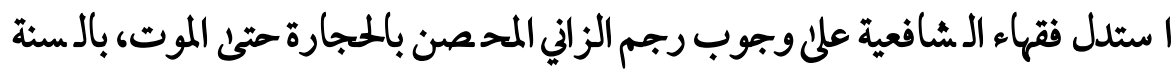

$$
\text { النبوية المطهة، والأثر الشريف، والإجماع. }
$$

ما عن جابر: أن رجلاً من أسـلم، جاء النبي صـلن الله عليه وســلم فاعترف بالزنا،

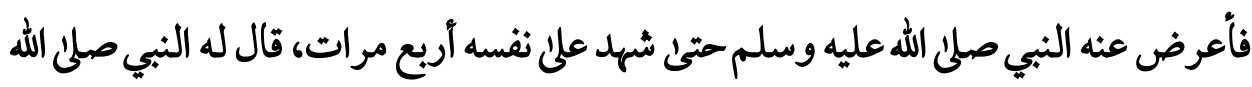

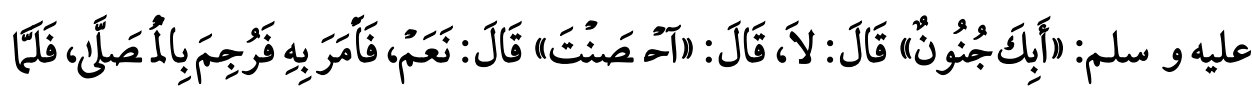

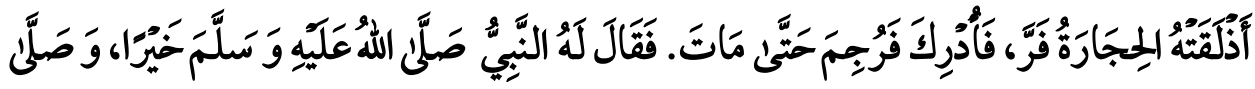

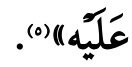

(') المحصن هو:" من وطنه في نكاح صحيح وهو حر بالغ عاقل" يراجع: الشيرازي أبو اسحاق إبراهيم بن علي

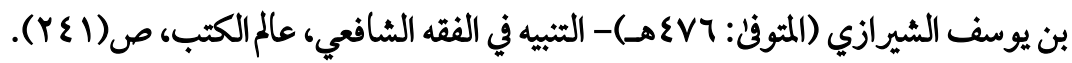

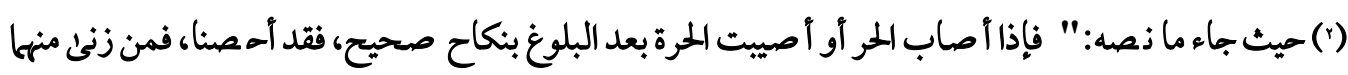

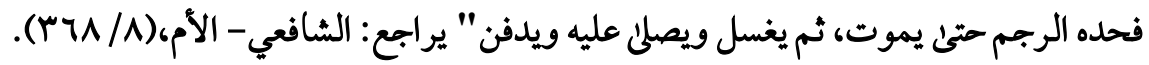

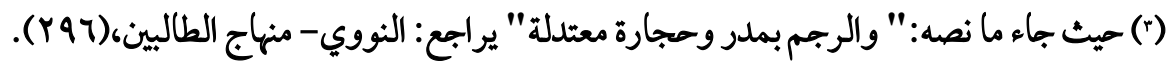

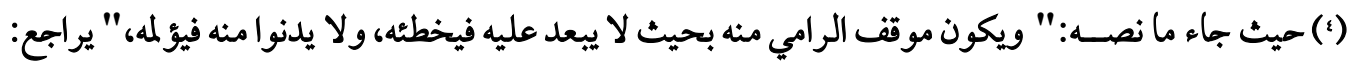

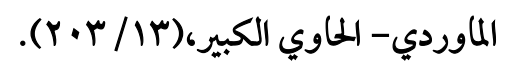

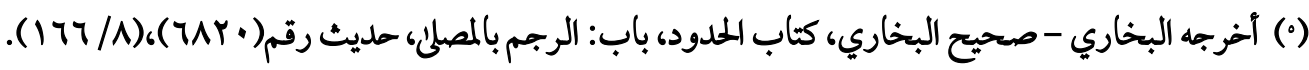


وجه الدلاكلة من الحدليث الشريف:

يدل هذا الحديث النبوي الشرـيف علئ اسـتحقاق الزاني المحصــن للقتل، وهو الرجم بالحجارة حتى الموت، حيث إن الرسول صلنى اللهعليه و سلم أمر برجم الرجل عندما اعترف

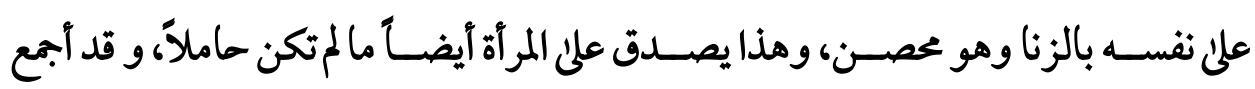

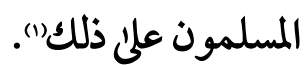

\section{ثانياً: من الأثر الشريف:}

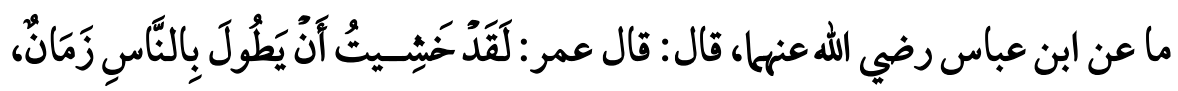

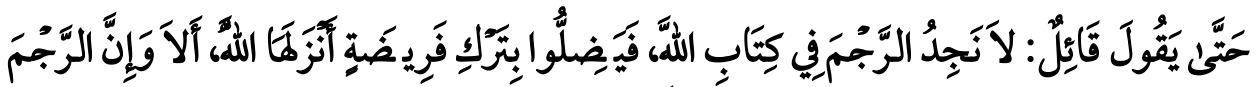

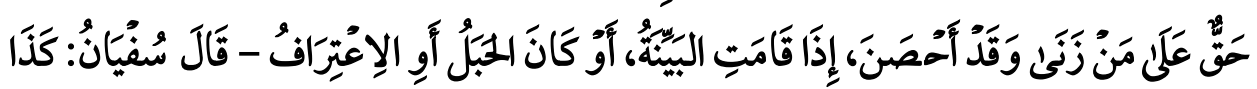

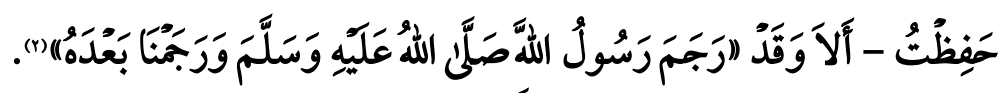
وجه الدلالة من الأثر الشريف:

يدل هذا الأثر الشريف على ثبوت الرجمفي حق الزاني المحصن، حيث أعلن سيدنا عمر بن اللطاب القول بالرجم وهو على المنبر، وسكت الصحابة وغيرهم من اللحاضرين عن خخالفته، والإنكار عليه، فكان ذلك بمثابة الإجماع منهم على ثبوته" (r). ثالثاً: من الإجماع:

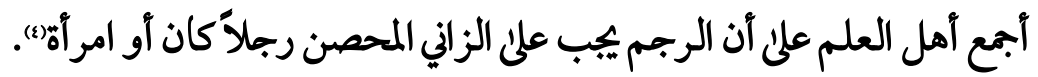
ب- أدلة وجوب الوسطية في حجم اللحجارة التي يرجم بها الزاني المحصن رجلا كان أو أو أوسي

(') بدر الدين العيني - عمدة القاري شرحصحيح البخاري،(ع / (ع)،بتصرف.

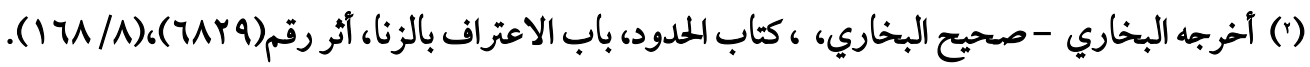

$$
\begin{aligned}
& \text { (r) النووي - المنهاج شرح صحيح مسلم،(11/ 191 )، بتصرف. } \\
& \text { (؛) النووي - المجموع شرح المهب؛، •r/ r/ ). }
\end{aligned}
$$


اسـتدل فقهاء الشــافعية علنئوجوب الوسـطية في حجم الحجارة التي يرجم بها الزاني المحصن رجلاً كان أو امرآة، بالمعقول: وذلك من أربعة وجوه:

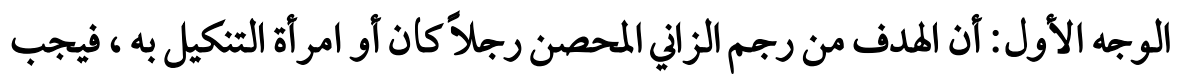
رجمه بحجارة معتدلة متوسطة الحجم لا بحصيات خفيفة، ليلا يطول تعذيبه، ولا بصخرات

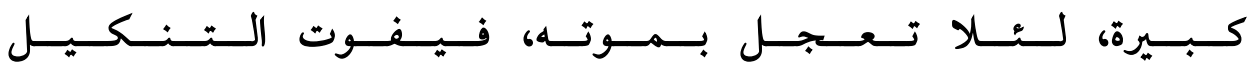
المقصود شرعاًا").

الوجه الثاني: أن الحجر الذي يرجم به الزاني المحصــن رجلاً كان أو إمرآة ييب أن يكون

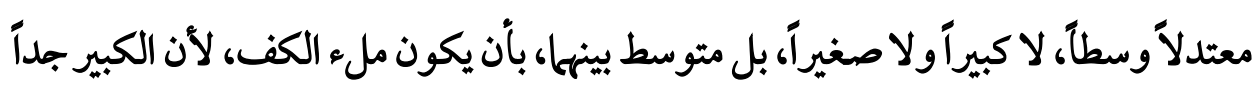

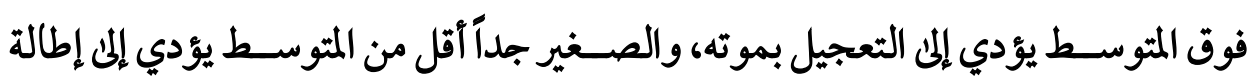
تعذيبه، وكلامما منوع شرعاً، فيجب مراعاة الو سط المعتدل في حجم الحجارة التي يرجم بها الزاني المحصن (1).

الوجه الثالث: أن موقف الراجم من الزاني المحصن لا بد آن يكون و سطاً معتدلاً، لأن

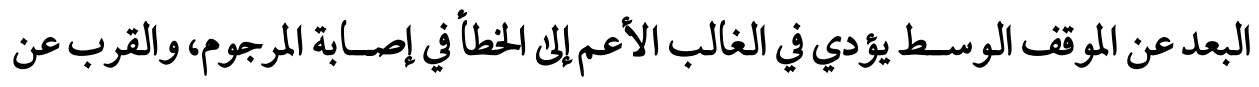

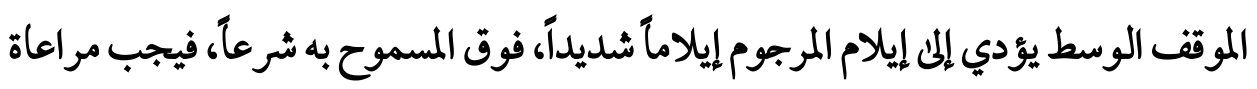
الوسط المعتدل في المسافة بين الراجم والمرجوم (r).

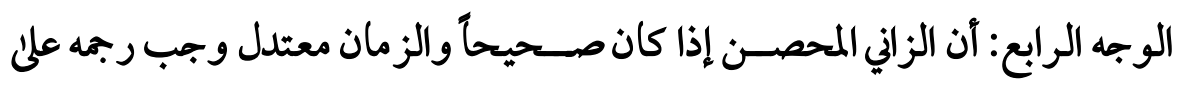

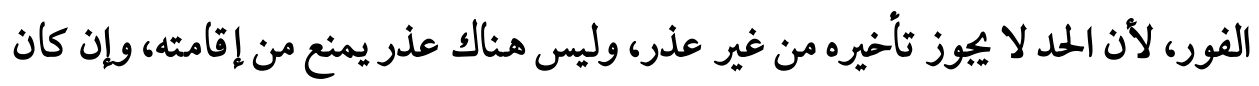

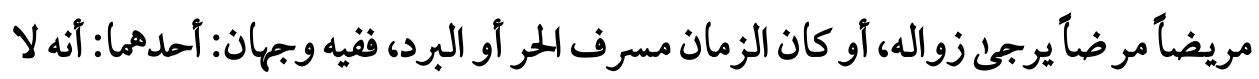

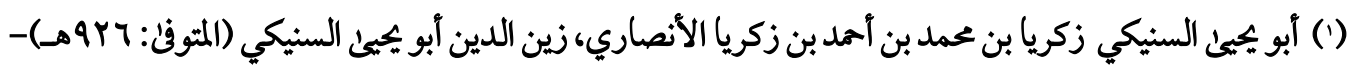

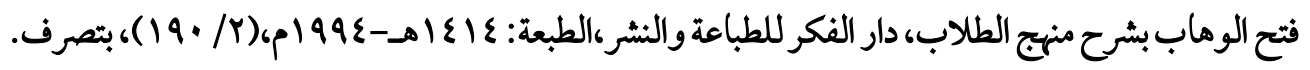

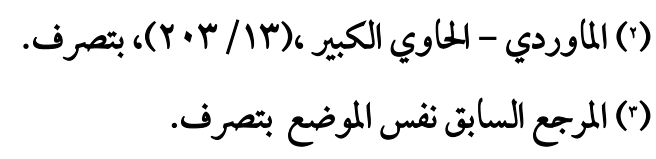


يؤجل رجمه، لأن القصد من الرجم قتله، فلا يمنع الحر والبردو المرض منه والثاني: أنه يؤخر،

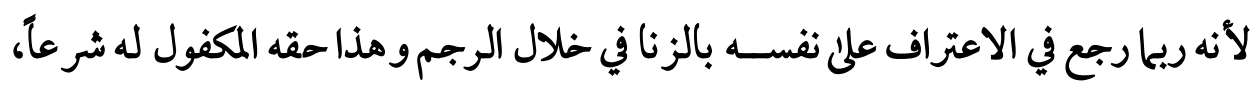
والحال أن الرجم قد آثر في جسمه، فيعين الحر والبرد والمرض علئ قتله زيادة على الحد المعتاد، وهو ما أرجحه، لأنه يجنح إلى الوسطية والاعتدال (1). 


\section{الفرعالثالث}

\section{الوبطية في رجم الزانية المحسنة}

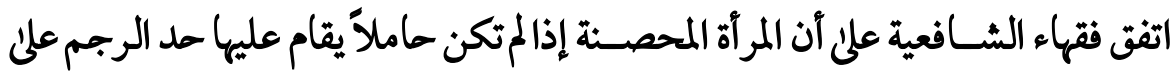

الفور (1)، واتفقوا على أنها إذا كانت حاملاًّ لا يقام عليها الحد حتى تضع حملها (r).

\section{الأدلة:}

استدل فقهاء الشافعية على أن المرآة الزانية المحصنة، إذا كانت حاملاًّا لا يقام عليها حد الأد

الرجم حتى تضع حملها، بالسنة النبوية المطهرة، والمعقول.

\section{أولاً: من السنة النبوية المطهرة:}

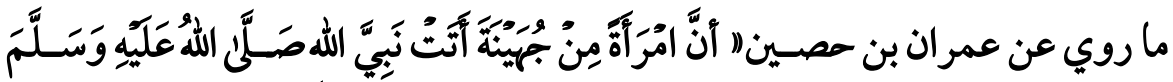

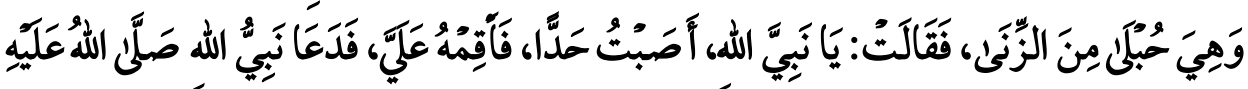

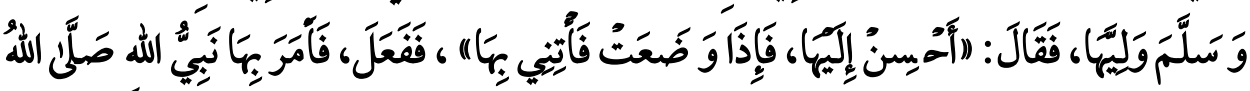

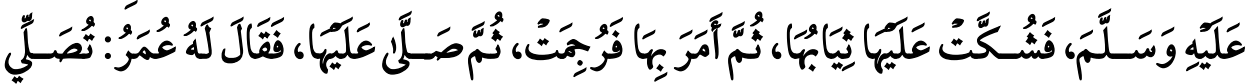

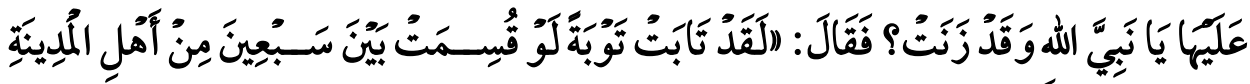

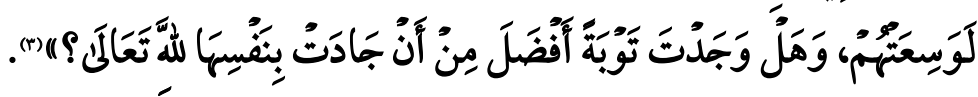

(') حيث جاء ما نصـه:" ويرجم المحصـن ... إلا أن تكون امرأة حبلن فتترك حتىل تضـع ويكفل ولدها"

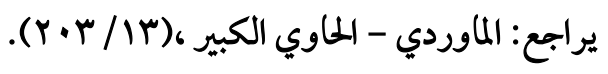

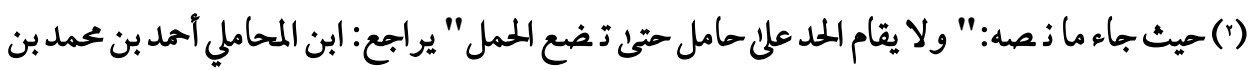

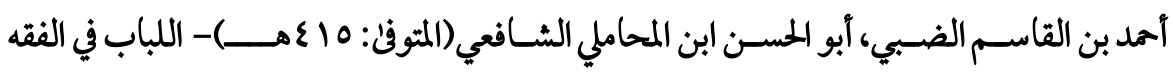

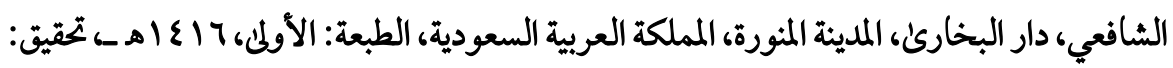

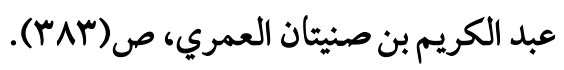

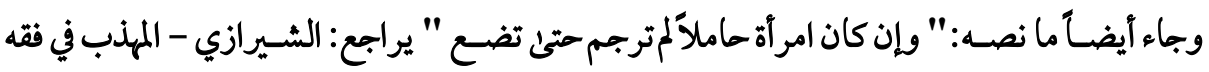

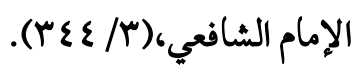

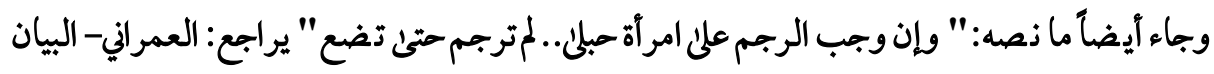

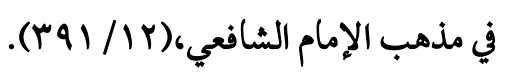

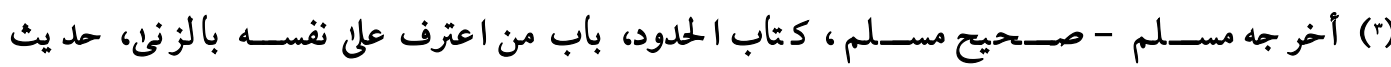

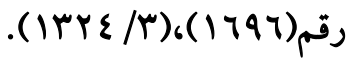


وجه الدلالة من الحديث الشريف:

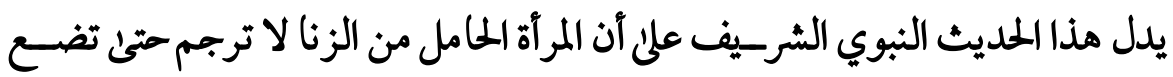

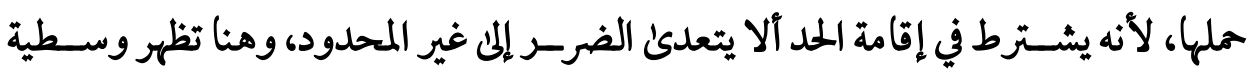

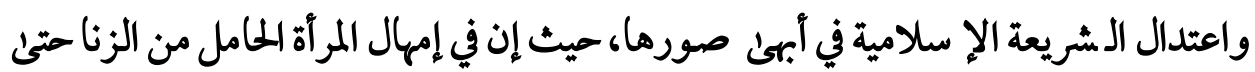
تضــ مملها محافظة على حياة الملنين من الملاك، وانتظار الوقت المناسـب لإقامة الحد مراعة لمقتضى اللحال (1) ثانياً: من المعقول: وذلك من ثلانة الكة وجوه:

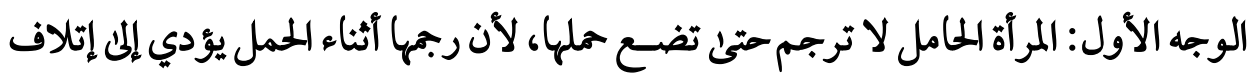
الجنين وهذا فيه ظلم بين للجنين واعتداء على حقه في الحياة، وهو أمر محرم شرعآم).

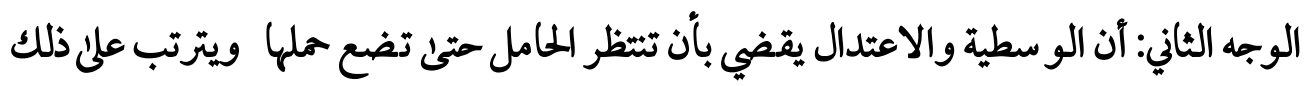
أمران: الأمر الأول: المحافظة على حياة المجنين من التلف وهو أمر واجب شرعاً.

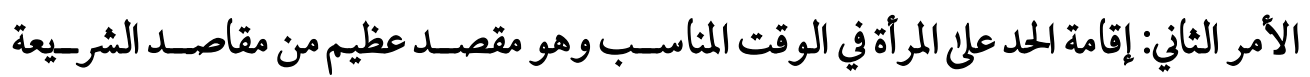
الإسلامية). (r) الوجه الثالث: إذالميوجد لرضاع الحمل بعد وضعه غير الأم يؤخر رجمها حتى ترضعه حولين

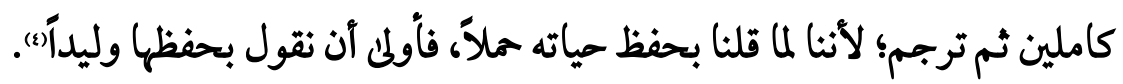

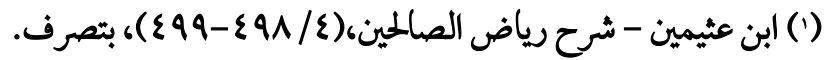

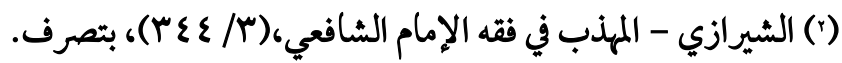

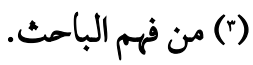

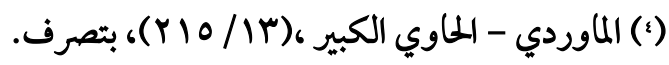




\section{الغاتة}

الحمد لله الذي بنعمته تتم الصلالحات، ويفضله تتحقق الغايات، وأصلي وأسلم علئ عبده النبي الأمي الذي بعثه الله رحمة للعالمين، أما بعد

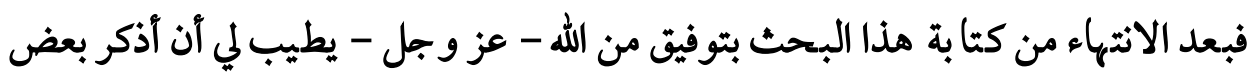
التنائج، والتوصيات التي توصلت إليها من خلال مذا البحث: أولأ؛ النتائج؛ قد ظهر لي من خلال هذا البحث العديد من التتائج أمها: ا - أن الإسلام يقدم المنهج الوسط في كل شأن من شئون الحياة. r- واقعية التشريع الإسلامي وارتباطه بالحوادث التي تقع.

ب- أن التراث الفقهي الإسـلامي يمتاز بالمرونة التي تجعله قادراً على التفاعل مع قضــايا الأمة الإسلامية، ووضع الحلول الناجعة لمشكلاتها بسهولة ويسر.

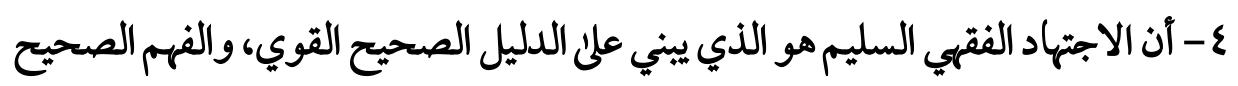
لهذا الدليل. ه- أن العلاقة بين الوسطية والاجتهاد الفقهي علاقة وثيقة وطيدة.

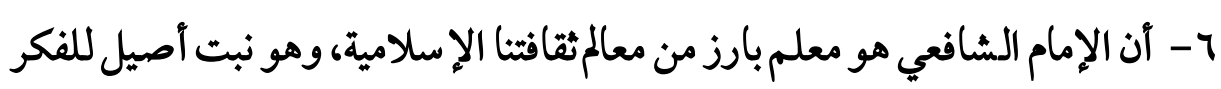
الإسلامي، وللعبقرية الإسلامية في الفقه والتشريع، وفي وضوح الفكرة وسمو التعبير عنها.

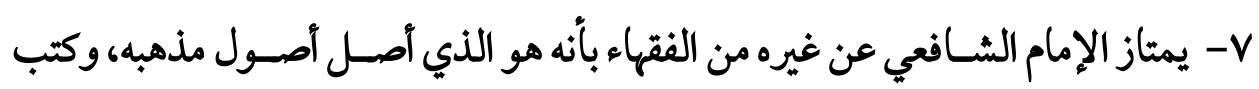
الكتب التي تعتبر مثنآلآلفقهه. 1- أن مذهب الإمام الثـافعي هو آقرب المذاهب الفقهية ارتباطاً بالدليل إذا عمل بقوله في

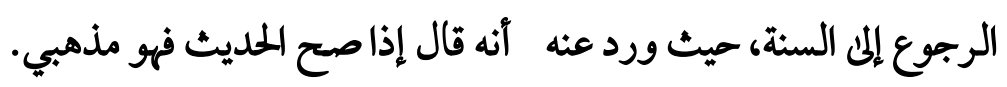
9- أن فقهاء الشافعية قد طبقوا فقه الأولويات حيث قدموا العبادات علئ المعاملات المات اهتحاما

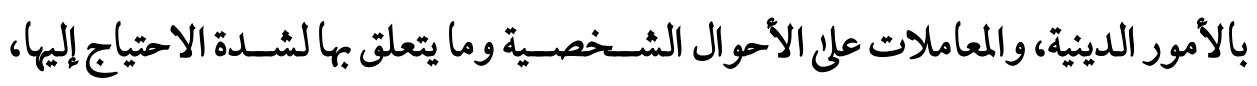


والأحوال الشخصية علئ الحدود؛ لأنها دونها في الحاجة، وأخروا الحدود لقلة وقوعها بالنسبة مله قلها.

\section{ثانيا ؛ التوصيات؛}

هناك العديد من التوصيات فييا يخص هذا البحث أهمها:

1- تصحيح المفاهيم الخاطئة فيما يتعلق بالمسائل الدينية الخطيرة.

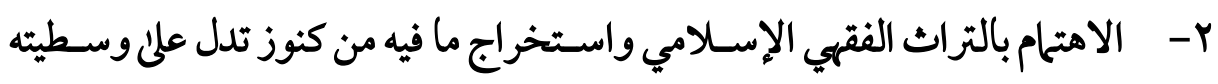

$$
\text { واعتداله في جميع بجالات الحياة. }
$$

r- - تناول مو ضوع الو سطية وعلاقتها بالاجتهاد الفقهي درا سة فقهية تطبيقية علي جميع

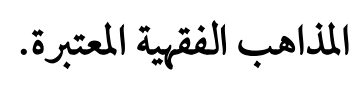

وأخر دعوانا أن الحمد لله رب العالمين 


\section{ههرس المصادروالمراجع}

القرآن الكريم:

أولاً: كتب التفسير وعلومهـ: الترين

ا - ابن المنذر أبو بكر محمد بن إبراهيم بن المنذر النيسابوري(المتوفف: 9 ابهـــ)- تفسير ابن

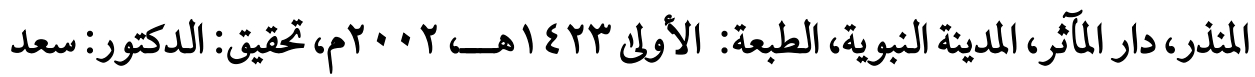
بن محمد السعد، تقديم: الأستاذ الدكتور: عبد الله بن عبد المحسن التركي. r- ابن جرير الطبري محمد بن جرير بن يزيد بن كثير بن غالب الآملي، أبو جعفر الطبري (المتوفى: · إهــــ) جامع البيان عن تأويل آي القرآن، الناشر: دار هجر للطباعة والنشر-

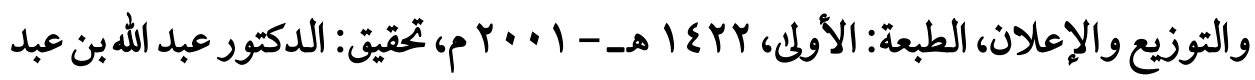
المحسن التركي. r- ابن عاشــور محمد الطاهر بن محمد بن محمد الطاهر بن عاثــور التونسي_(المتوفى : بهץ (هـ)- التحرير والتنوير، الدار التونسية للنشر، تونس، ع^ه اهـ. ع - د/ وهبة بن مـصطفى الزحيلي- التف سير المنير في العقيدة والششريعة والمنهج، دار الفكر المعاصر، دمشق، الطبعة : الثانية ، 11 ع أهـ 0 - د/ وهبة بن مصطفى الزحيلي- التفسير الو سيط للزحيلي، الناشر: دار الفكر ، دمشق،

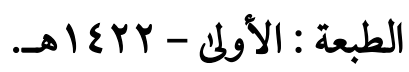
7- الدكتور محمد سيد طنطاوي- التفسير الوسيط للقرآن الكريم، دار نهضة مصر للطباعة والنشر والتوزيع، الفجالة، القاهرة، الطبعة: الأولى: 99 ام. -V الشافعي أبو عبد اللهمحمد بن إدريس بن العباس بن عثمان بن شافع بن عبد المطلب بن عبد مناف المطلبي القرثي المكي (المتوفن: ع · بهــ)- تفسير الإمام الشافعي، دار التدمرية،

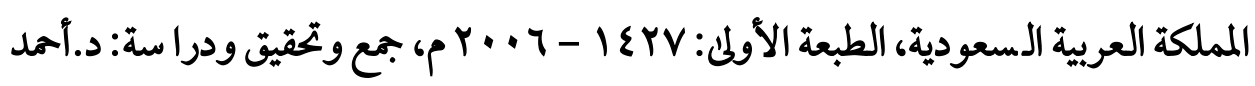
بن مصطفى الفرَّان (رسالة دكتوراه). 
1- القرطبي أبو عبد اللدحمد بن أحمد بن أبي بكر بن فرح الأنصاري الحزرجي شمس الدين

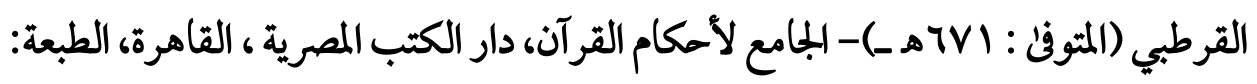

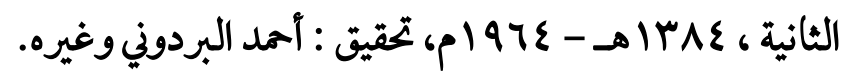

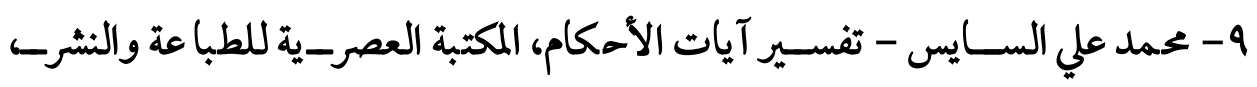

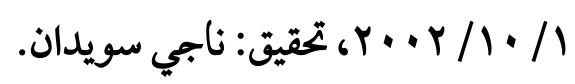

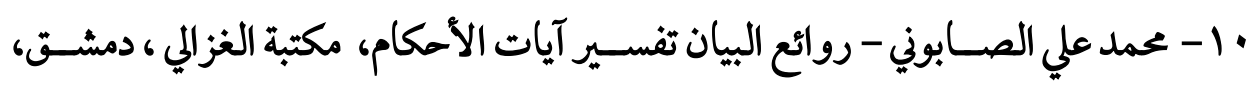

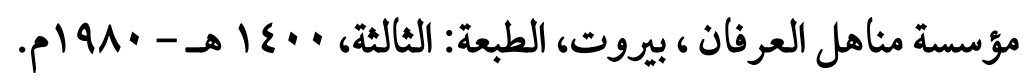

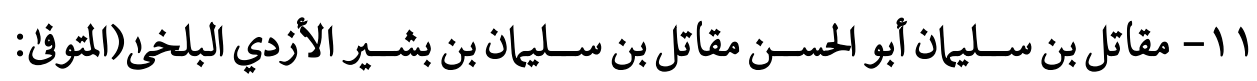

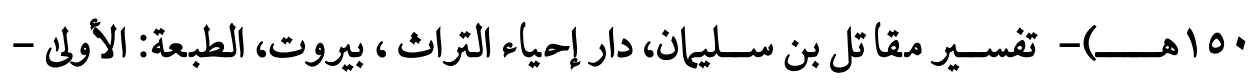
r r ا ا هـ،تحقيق: عبد الله محمود شحاته. ثانياً: كتب الحديث وملومه:

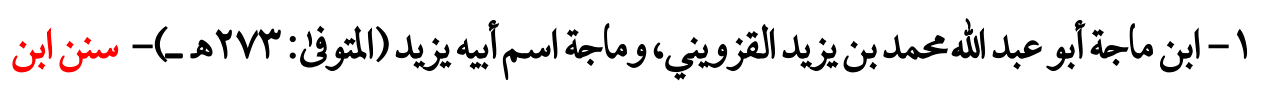
ماجه، دار إحياء الكتب العربية، فيصل عيسى البابي الملبي، تحقيق: محمد فؤاد عبد الباقي.

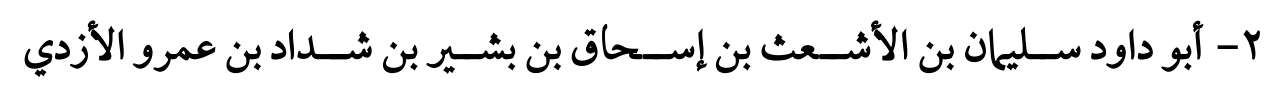

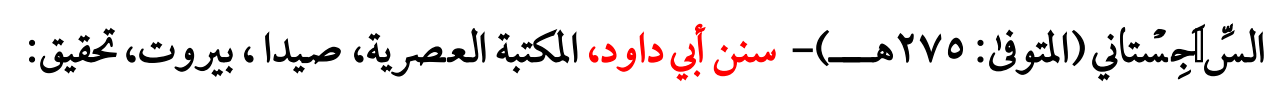
محمد محيي الدين عبد الحميد. ب- الإمام أحمد بن حنبل أبو عبد اللهأحمد بن محمد بن حنبل بن هلال بن أسد الشيباني(المتوفن:

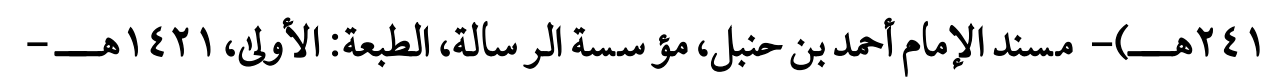

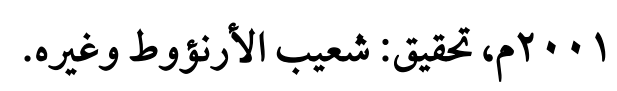
ع - البخاري محمد بن إسماعيل أبو عبدالله البخاري البعفي - صحيح البخاري، الناشر : دار

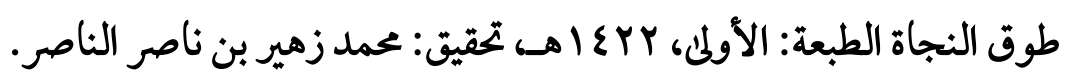

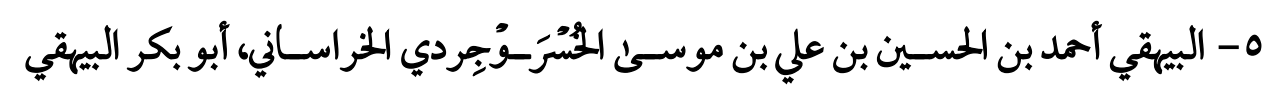




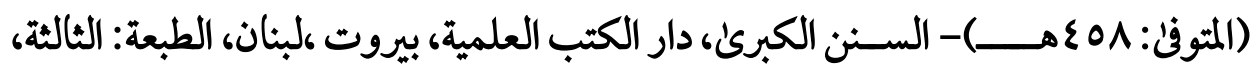

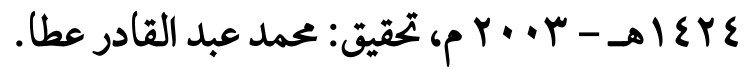
7 - اللحاكم أبو عبد الله الحاكم محمد بن عبد الله بن محمد بن حمدويه بن نُعيم بن الحكم الضسبي الطهاني النيسابوري المعروف بابن البيع (المتوفن: 0 • عـهــ- المستدرك على الصحيحين، دار الكتب العلمية ، بيروت، الطبعة: الأولى، || | | | هـ - - 99 (م، تحقيق: مصطفى عبدالقادر (b) -V الدارقطني أبو الحســن علي بن عمر بن أمد بن مهدي بن مسـعود بن النعان بن دينار البغدادي الدارقطني (المتوفن: ^^هــ)- سنن الدارقطني، مؤسسة الرسالة، بيروت ، لبنان، الطبعة: الأولم، ع ع ع أهـ - ع + . r م، تحقيق: شعيب الارنؤوط، وغيره. 1- الـشافعي أبو عبد الله محمد بن إدريس بن العباس بن عثمان بن شافع بن عبد المطلب بن عبد مناف المطلبي القرشي المكي (المتوفن: ع • بهـــــ المـــند، دار الكتب العلمية، بيروت،

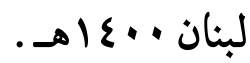

ه- الطبراني سـليان بن أحمد بن أيوب بن مطير اللخمي الثـــامي، أبو القاســم الطبراني (المتوفن: · · بهـ -) المعجم الكبير، مكتبة ابن تيمية ، القاهرة، الطبعة: الثانية، تحقيق: حمدي بن عبد المجيد السلفي. • 1 - عبد الرزاق أبو بكر عبد الرزاق بن همام بن نافع الحميري الياني الصـنعاني(المتوفن:

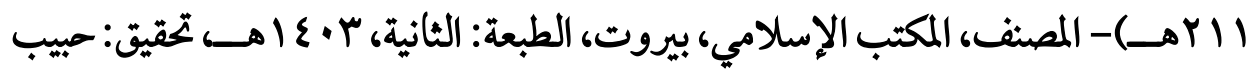

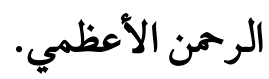
| 1 - مسلم بن الحجاج أبو الحسن القشيري النيسابوري(المتوفن: (ا7 بهـ)- صحيح مسلم، دار إحياء التراث العربي ، بيروت، تحقيق: محمد فؤاد عبد الباقي. r ا - النسائي أبو عبد الرحمن أحمد بن شعيب بن علي الخراساني، النسائي (المتوفن: ب • بهـ)-

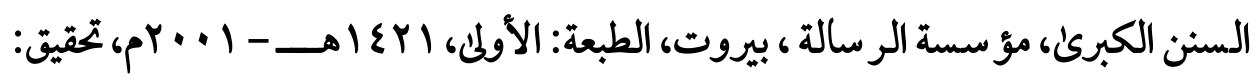


حسن عبد المنعم شلبي.

ما - ابن الجوزي جمال الدين أبو الفرج ع بد الرحمن بن علي بن محمد الجوزي(المتوفن: 9 0هـ - - كشف المشكل من حديث الصحيحين، دار الوطن ، الرياض، تحقيق: علي حسين البواب. ع ا - ابن حجر أممد بن علي بن حجر أبو الفضـل العسـقلاني الشـافعي- فتح الباري شرح صحيح البخاري، دار المعرفة ، بيروت، و I I ، تحقيق محمد فؤاد عبد الباقي وغيره. 10 - ابن رجب زين الدين عبد الرحمن بن أحمد بن رجب بن الحسن، الـسَلامي، البغدادي، ثم الدمشقي، الحنبلي (المتوفن: 90Vهـ)- فتح الباري شرح صحيح البخاري، الناشر: مكتبة

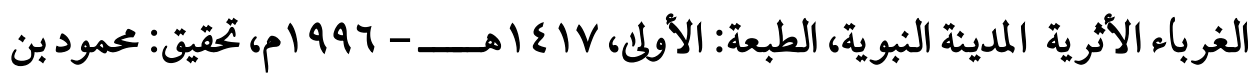
شعبان بن عبد المقصود. 17 - ابن عبد البر أبو عمر يوســف بن عبد الله بن محمد بن عبد البر بن عاصــم النمري

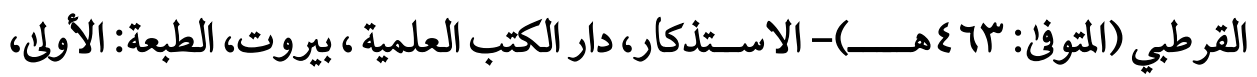

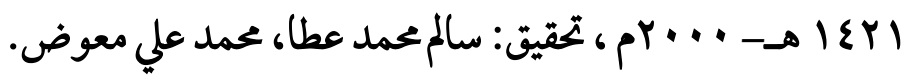
ا - ابن عبد البر أبو عمر يوسـف بن عبد الله بن محمد بن عبد البر بن عاصــم النمري

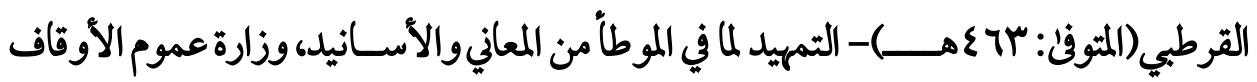
والشؤون الإسلامية ، المغرب ، I I I هـ ، تحقيق: مصطفى بن أحمد العلوي وغيره. 1| - ابن عثيمين محمد بن صـالح بن محمد العثيمين(المتوفن: إY ع ا هـــــ- شرح رياض

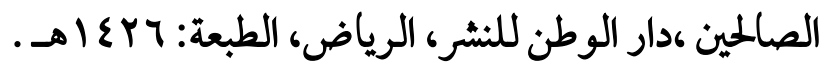
9 ا - ابن علان محمد علي بن محمد بن علان بن إبراهيم البكري الصديقي الشافعي(المتوفن: OV P I ا هـــ) - دليل الفالحين، دار المعرفة للطباعة والنشر والتوزيع، بيروت ، لبنان، الطبعة:

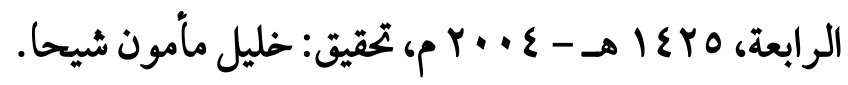
• r- أبو عبد الله، عبد الرحمن بن ناصر بن عبد الله بن ناصر بن حمد آل سـعدي(المتوفن: 


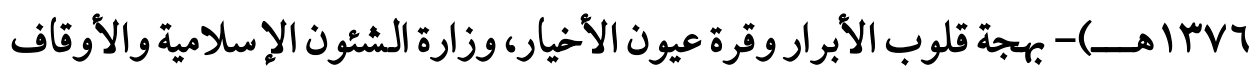
والدعوة والإرشاد، المملكة العربية السعودية، الطبعة: الرابعة، بrع اهــ.

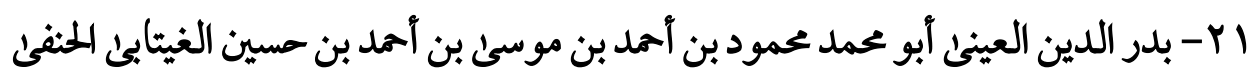

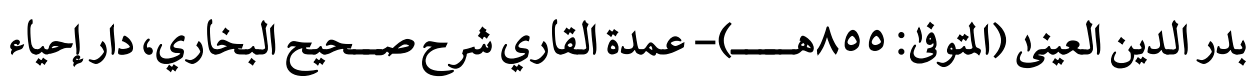

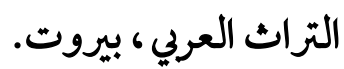

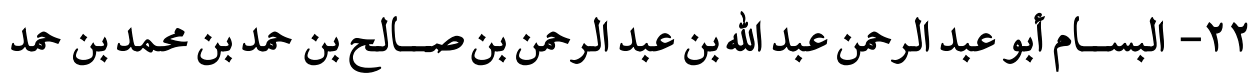

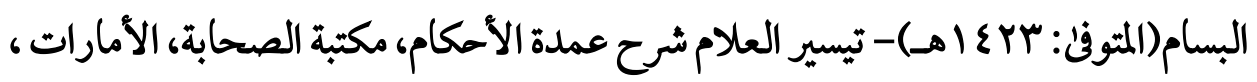

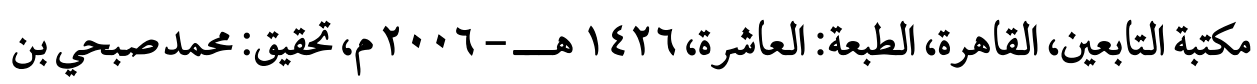
حسن حلاق. بr - اللخطابي أبو سـليان محد بن محمد بن إبراهيم بن اللخطاب البستي المعروف بللخطابي(المتوفن:

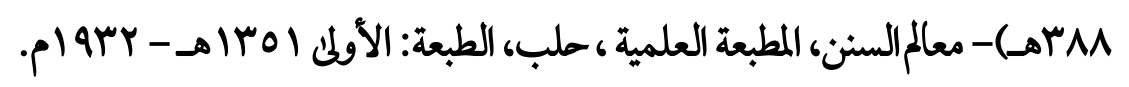

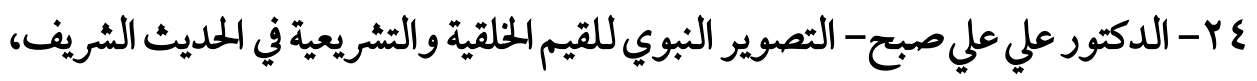

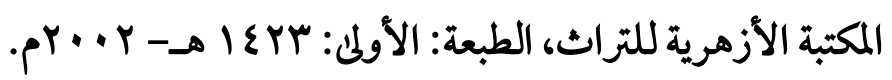

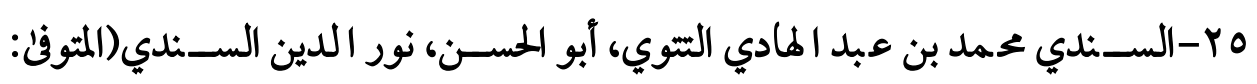

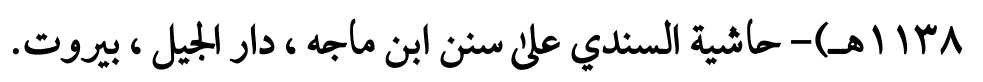

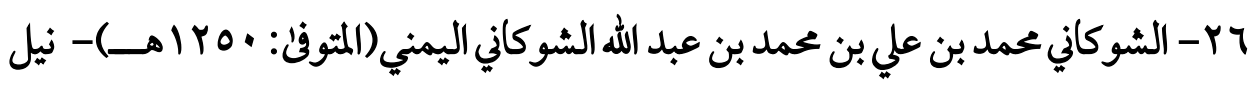

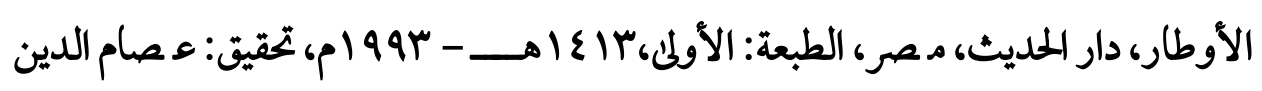
الصبابطي. الصنع - YV

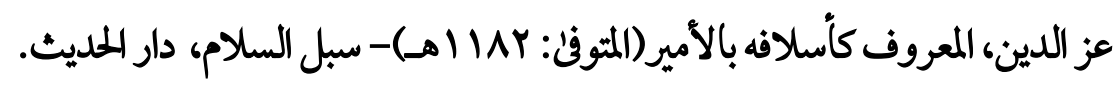

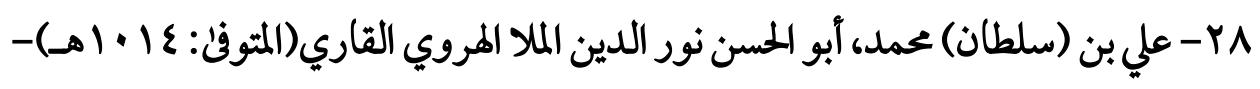

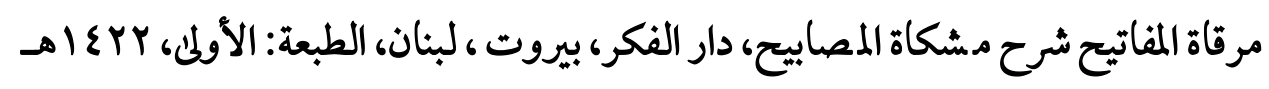


ه r- المباركفوري أبو الحســن عبيد الله بن محمد عبد السـلام بن خان محمد بن أمان الله بن

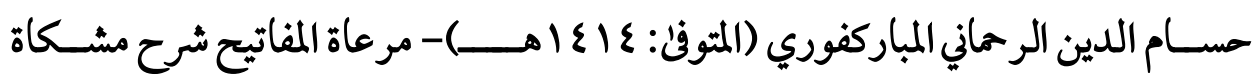
المصـابيح،إدارة البحوث العلمية والدعوة والإفتاء، الجامعة السـلفية ، بنارس المند،الطبعة:

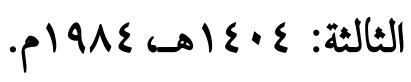
• بـ المناوي زين الدين محمد المدعو بعبد الرؤوف بن تاج العارفين بن علي بن زين العابدين

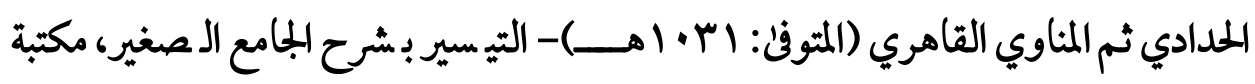

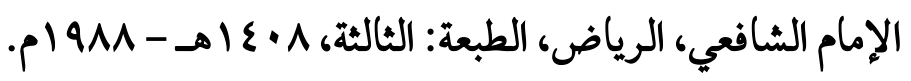
اب- المناوي زين الدين محمد المدعو بعبد الرؤوف بن تاج العارفين بن علي بن زين

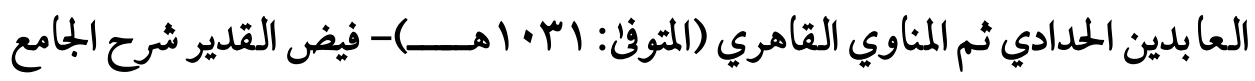

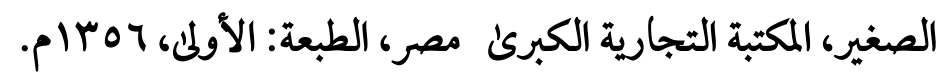

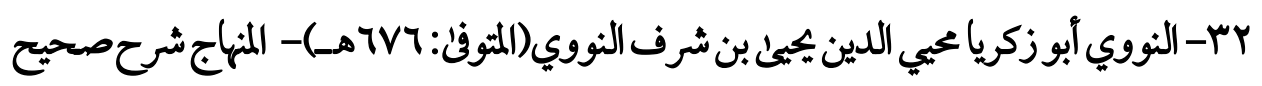

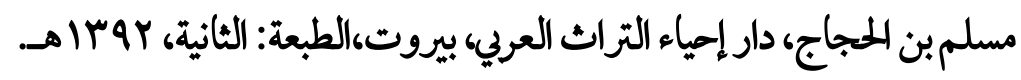
بـ- ابن الملقن سراج الدين أبو حفص عمر بن علي بن أحمد الششافعي المصري (المتوفن: ع •^هــــ- البدر المنير، الناشر: دار المجرة للنشر والتوزيع ، الرياض، السعودية، الطبعة:

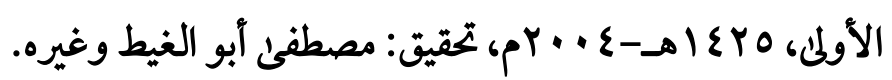
ع ؟ـ- ابن الملقن سراج الدين أبو حفص عمر بن علي بن أحمد الثـافعي المصرـي (المثوفن:

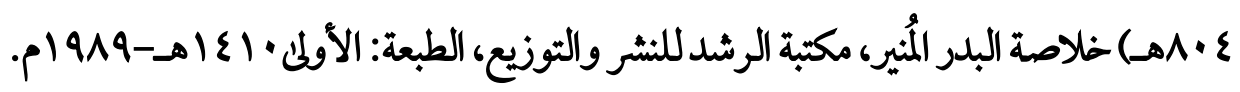
هب- ابن حجر العسقلاني أبو الفضل أحمد بن علي بن محمد بن أحمد بن حجر العسقلاني (المتوفن:

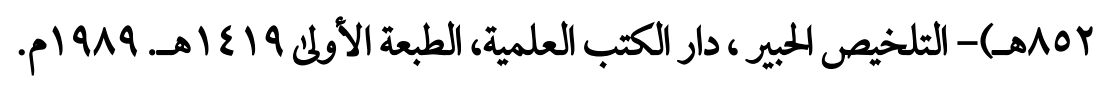
Tr- النووي أبو زكريا محيي الدين يجيل بن شرف النووي(المتوفن : TVTهـــ- خلاصة

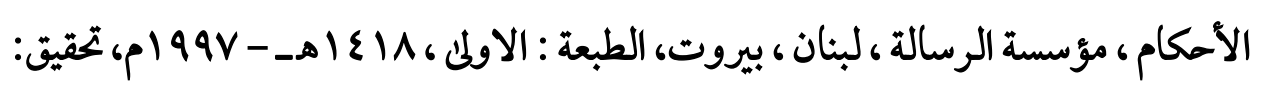


حسين إسماعيل الجمل.

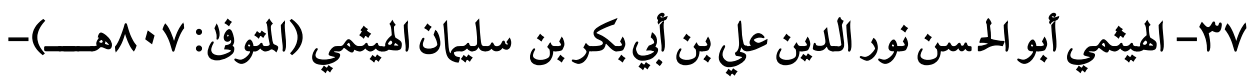

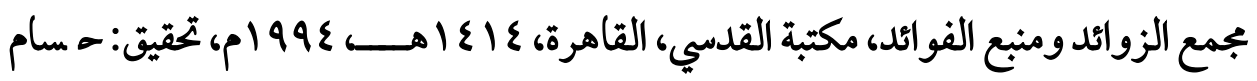
الدين القدسي. ثالثاً: كتب الفقه وأصوله وقواعده:

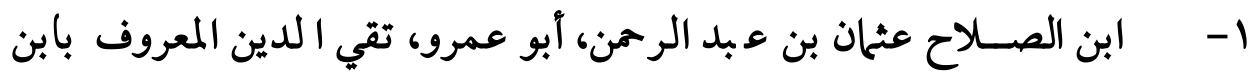

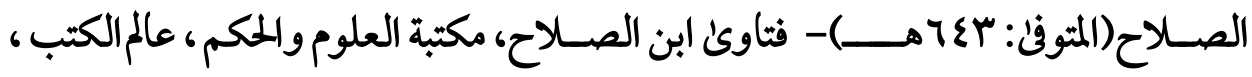

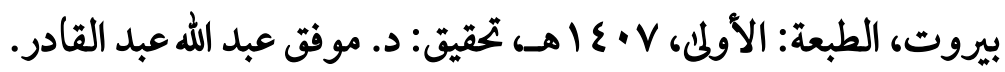

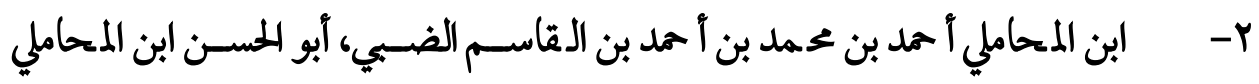
الشافعي (المثوفن: 10 عهــا - اللباب في الفقه الشافعي، دار البخارئ، المدينة المنورة، المملكة العريية السعودية، الطبعة: الأولى، 7 ( أ (هـ تحقيق: عبد الكريم بن صنيتان العمري.

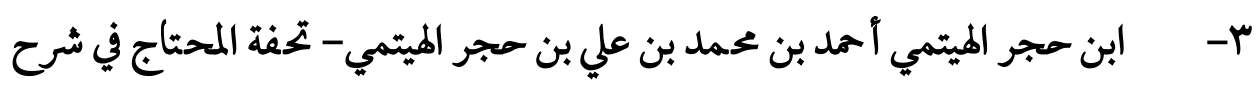

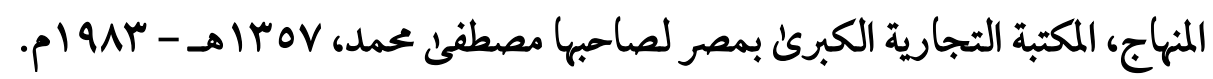

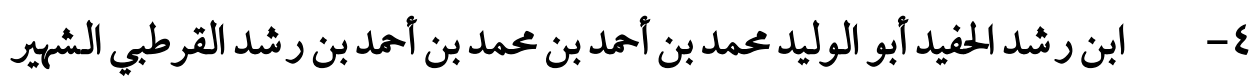

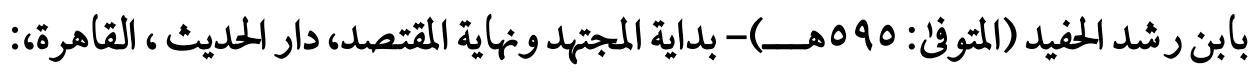

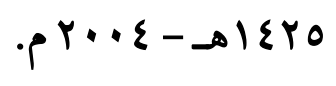

- - أبو شجاع أحمد بن الحسين بن أحمد، أبو شجاع، شهاب الدين أبو الطيب الأصفهاني (المتوفن: سوهـهـ) - متن أبي شجاع، عالم الكتب. 7- أبو مصعب محمد صبحي بن حسن حلاق- الإيضاحات العصرية للمقايس والمكاييل

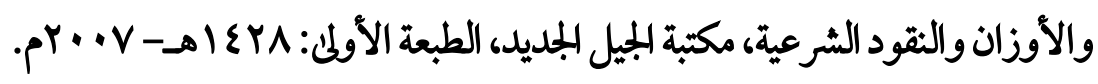

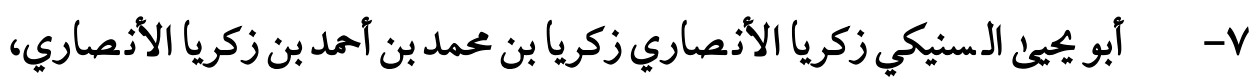

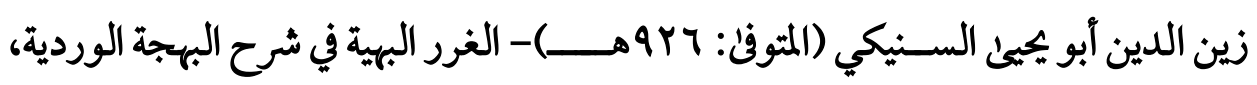


المطبعة الميمنية.

1- أبو يجيح السنيكي زكريا بن محمد بن أمد بن زكريا الأنصاري، زين الدين أبو يجيل السنيكي (المتوفن: 7 Y Y هـ)- فتح الوهاب بشرح منهج الطلاب، دار الفكر للطباعة والنشر، الطبعة: عاع اهـ- ع (99 ام.

9- أبو يجين السـيكي زكريا بن محمد بن زكريا الأنصـاري، زين الدين أبو يجين السـيكي (المتوفن: 7 9 هـ) - آسنى المطالب في شرح روض الطالب، دار الكتاب الإسلامي. • ا - الأســاذ الدكتور/ وهبة الزحيلي - الفقه الإســلامي وأدلته، دار الفكر، ســورية ،

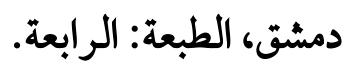
| 1 - إمام الحرمين عبد الملك بن عبد اللهبن يوسف بن محمد الجويني، أبو المعالي، ركن الدين، الملقب بإمام الحرمين (المتوفن: عV^هــ) - نهاية المطلب في دراية المذهب، دار المنهاج، الطبعة:

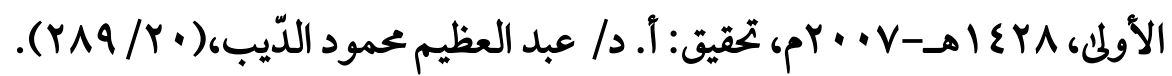

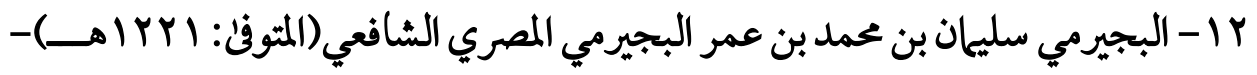
حاشية البجيرمي على الخطيب، دار الفكر، 0 (1ع (هـ - 990 (1)، (1V0) ). با - الحصــي أبو بكر بن محمد بن عبد المؤمن بن حريز بن معلنى الحسـيني الحصسـي، تقي

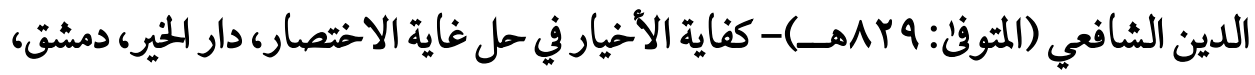
الطبعة: الأولنه، ع99 ام، تحقيق: علي عبد الحميد بلطجي وغيره. ع ا - اللخطيب ال شربيني شمس الدين، محمد بن أحمد الخطيب الشربيني الشافعي (المتوفن: 9VV $.0199 \varepsilon-ه \mid<10$ 0 - الخطيب الشر-بيني شـمس الدين، محمد بن أحمد الخطيب الشر-بيني الثـافعي(المتوفن: 9VV البحوث والدراسات - دار الفكر. 
17 - الدمياطي أبو بكر" المشههور بالبكري" بن محمد شـطا الدمياطي(المثوفن: بعد

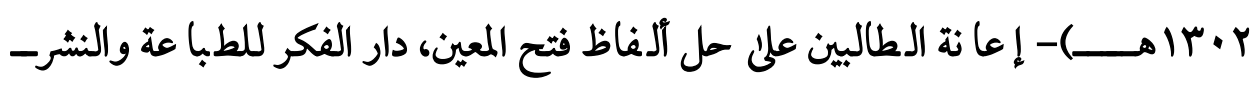

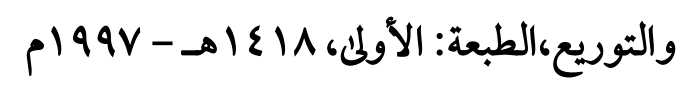

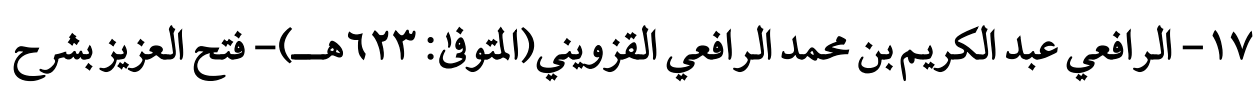

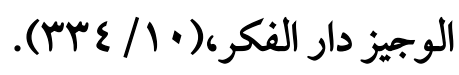

11 - الرملي شـمس الدين محمد بن أبي العباس أمد بن حمزة شـهاب الدين الرملي (المتوفن:

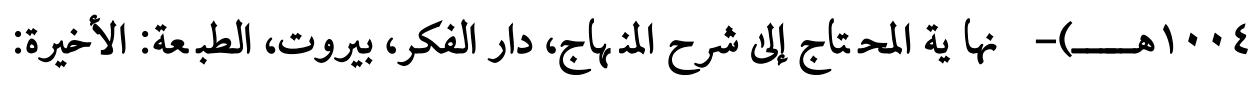

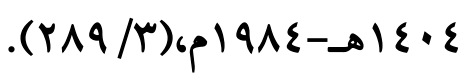

19 - سيد سابق(المتوفن: • ب ع (هـ) - فقه السنة، دار الكتاب العربي، بيروت، لبنان، الطبعة:

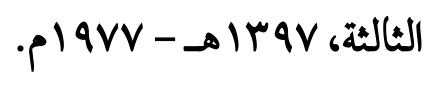

• . - الثافعي أبو عبد اللهمحمد بن إدريس بن العباس بن عثلان بن شافع بن عبد المطلب بن

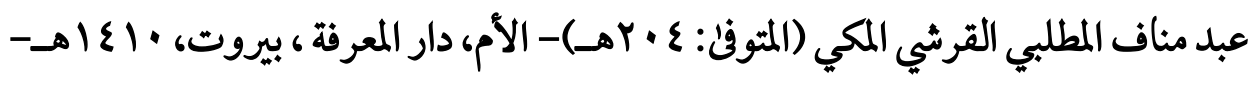
. $(r \Lambda \cdot / r)$ cp 199 .

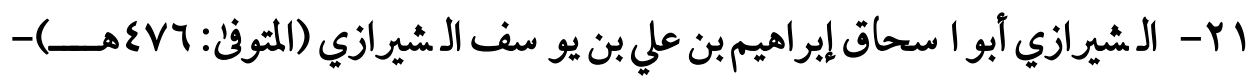
المذب في فقه الإمام الشافعي، دار الكتب العلمية.

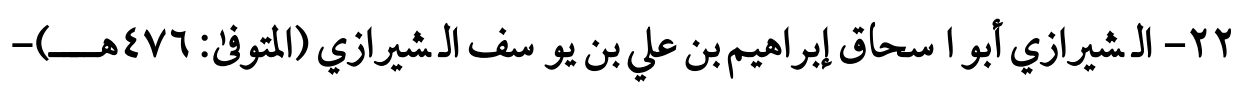
التبيه في الفقه الشافعي، عالم الكتب.

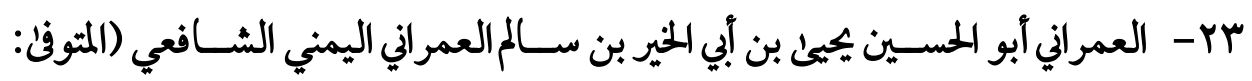

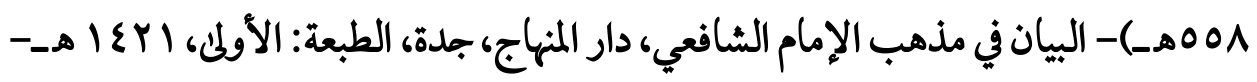

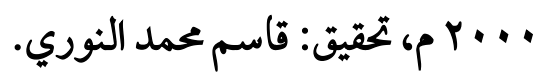

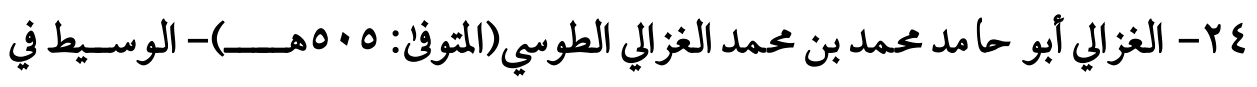

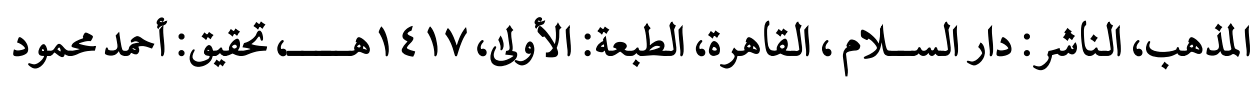


إبراهيم وغيره. ه - الغمراوي العلامة محمد الزهري الغمراوي (المتوفن: بعد Vrس اهـ)- السراج الوهاج دار المعرفة للطباعة والنشر، بيروت.

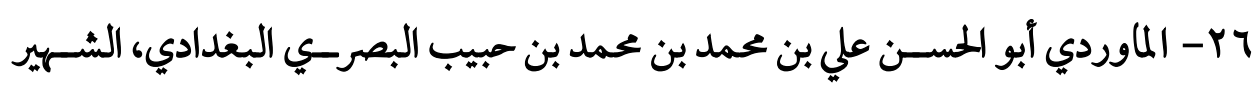

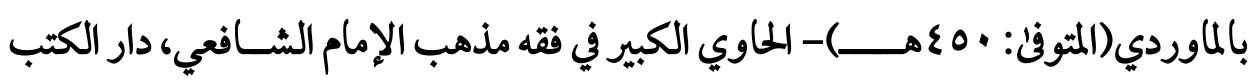

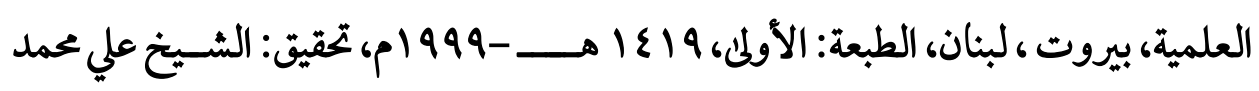
معوض وغيره.

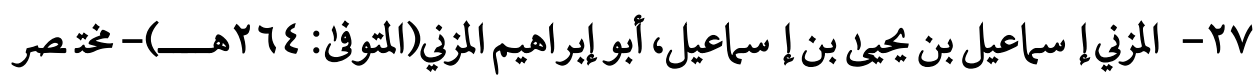

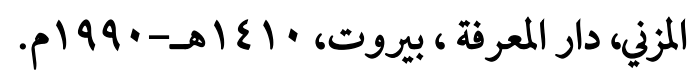
A - المنهاجي شـمس الدين محمد بن أحمد بن علي بن عبد الخالق، المنهاجي الأسـيوطي ثم القاهري الشافعي (المتوفن: • •1^هـــ)- جواهر العقود ومعين القضاة والموقعين والشهود، دار الكتب العلمية بيروت ، لبنان، الطبعة: الأولم، V | ع ا هـ - 1997 | متحقيق: مسعد عبد اللحميد محمد السعدني.

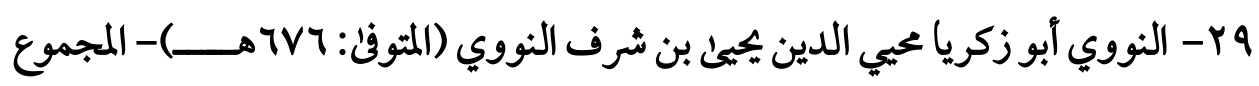
شرح المهذب، دار الفكر.

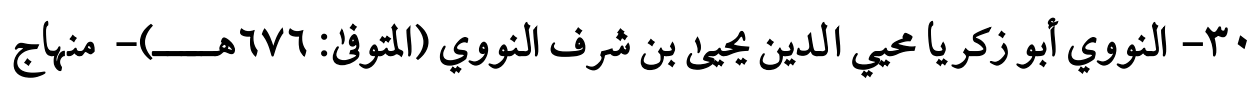

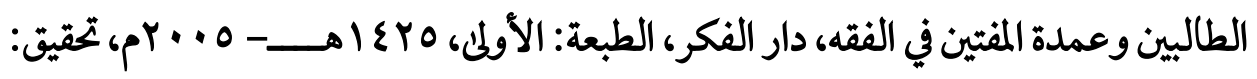
عوض قاسم أحمد عوض. ابـ- الهندي زين الدين أ حمد بن عبد العزيز بن زين الدين بن علي بن أ حمد المعبري المليباري المندي(المتوفن: 9AV هـ) - فتح المعين بشرح قرة العين، دار بن حزم، الطبعة: الأولى

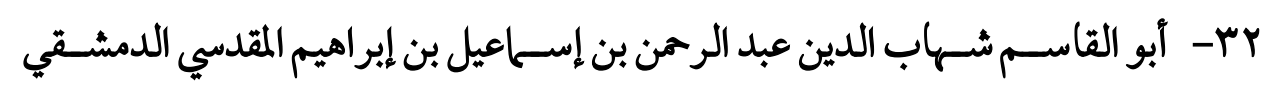

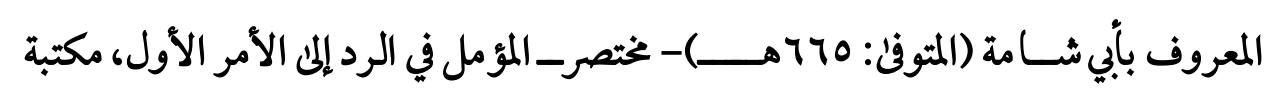


الصحوة الإسلامية - الكويت، سنة النشر: ب.ع (هـ، تحقيق:صلاح الدين مقبول أحمد.

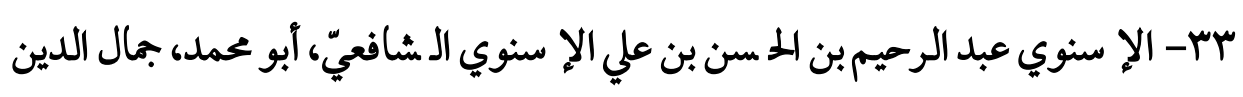

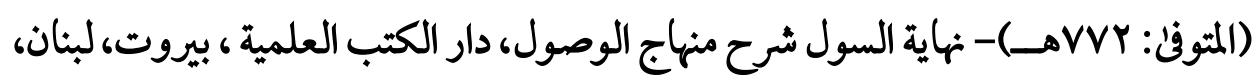

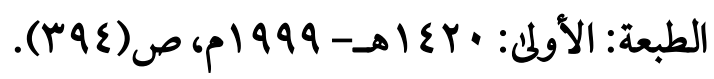

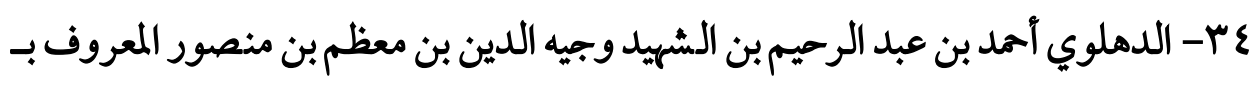

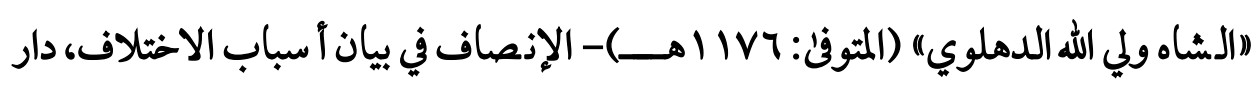
النفائس، بيروت، الطبعة: الثانية، ع • ع ( هـ، تحقيق: عبد الفتاح أبو غدة. هr- الشاطبي إبراهيم بن مو سلى بن محمد اللخمي الغرناطي الشهير بالشاطبي (المتوفن:

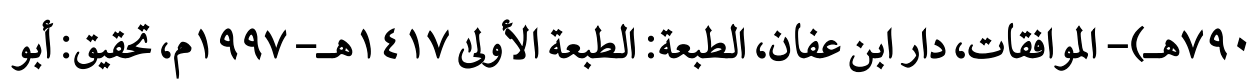
عبيدة مشهور بن حسن آل سلمان. جب- ابن بهادر الزركشي أبو عبد اللهبدر الدين محمد بن عبد اللهبن بهادر الزركشي (المتوفن:

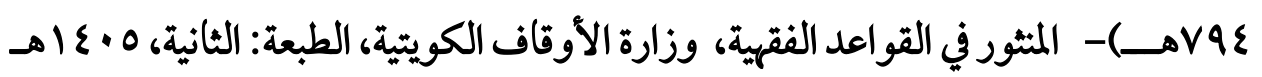
. $1910-$

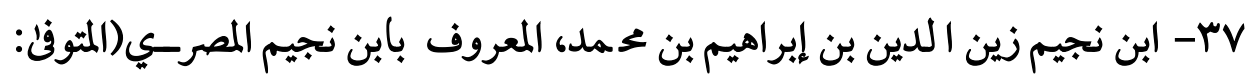

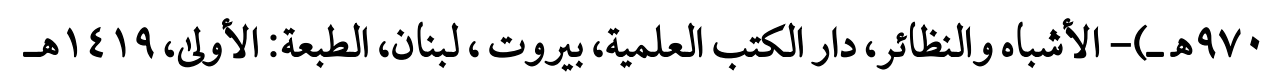
- 1999 199، تحقيق: الشيخ زكريا عميرات. Al- الدكتور محمد مصـطفى الزحيلي- القواعد الفقهية وتطبيقاتها في المذاهب الأربعة، دار

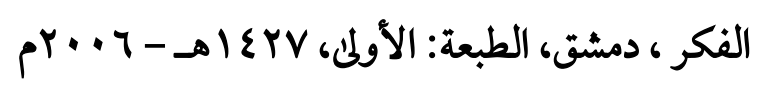

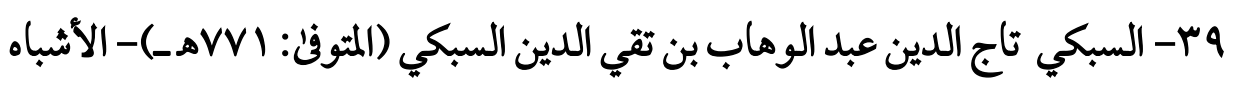

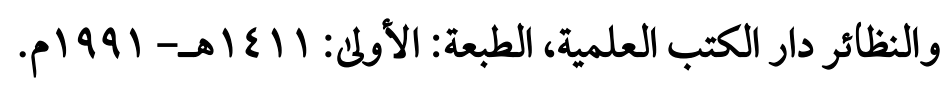

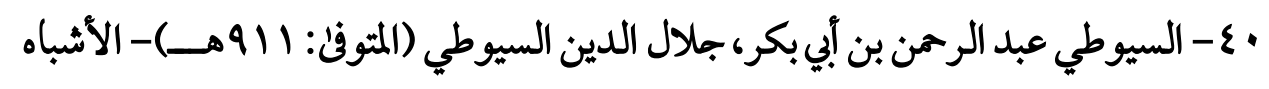

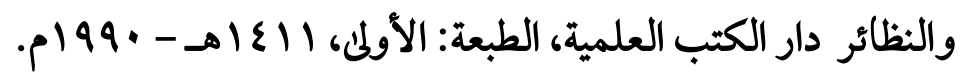




\section{رابعاً كتب اللغة والتراجم:}

ا - ابن الأثير بجد الدين أبو السـعادات المبارك بن محمد بن محمد بن محمد ابن عبد الكريم الثــيباني الجزري ابن الآثير (المتوفن: 7 • 7هــــــ- النهاية في غريب الحديث والأثر، المكتبة العلمية، بيروت، 99 ب أهـ - 9 ( ام، تحقيق: طاهر أحمد الزاوئ وغيره.

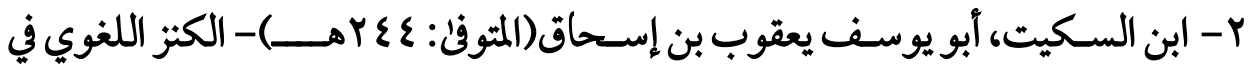
اللَّسن العربي، مكتبة المتنبي ، القاهرة، تحقيق: أوغست هفنر، r- ابن فارس أحمد بن فارس بن زكرياء القزويني الرازي، أبو الحسين(المتوفن: ه0هـــــ-

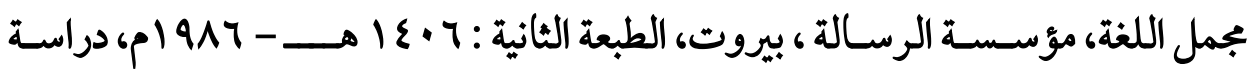
وتحقيق: زهير عبد المحسن سلطان. ع - ابن فارس أحمد بن فارس بن زكرياء القزويني الرازي، أبو الحسين(المتوفن: هوسهـــ-

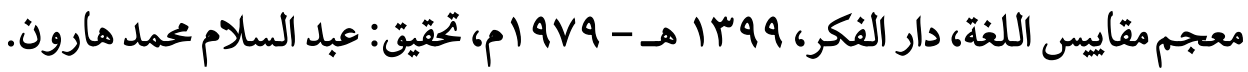
ه- ابن منظور محمد بن مكرم بن على، أبو الفضــل، جمال الدين ابن منظور الأنصــاري الرويفعى الإفريقى (المتوفن: IIهـ)- لسان العرب، دار صادر ، بيروت، الطبعة: الثالثة: ع.

ج- الأزهري محمد بن أحمد بن الأزهري المروي، أبو منصور (المتوفن: · VIهـ - تهذيب اللغة، دار إحياء التراث العربي، بيروت، الطبعة: الأولم، ا + +. بم، تحقيق: محمد عوض مرعب. V- الجوهري أبو نصر إسماعيل بن حماد الجوهري الفارابي (المتوفن: سه بهـ)- الصحاح تاج

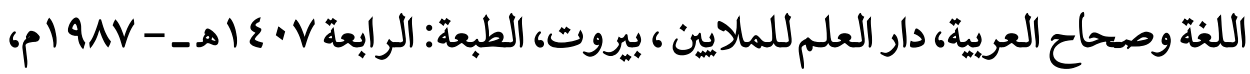
تحقيق: أحمد عبد الغفور عطار.

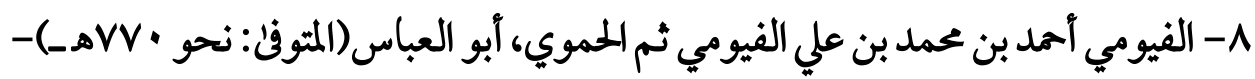
المصباح المنير في غريب الشرح الكبير، المكتبة العلمية ، بيروت. 9- القاضي عبد النبي بن عبد الر سول الأحمد نكري(المتوفن: ق ب ا هـــ)- دستور العلم)ء 6 


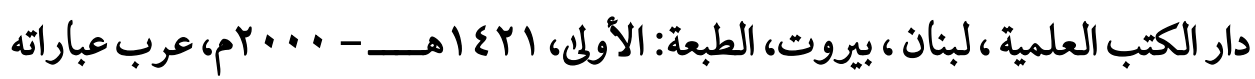

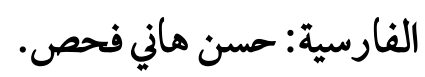

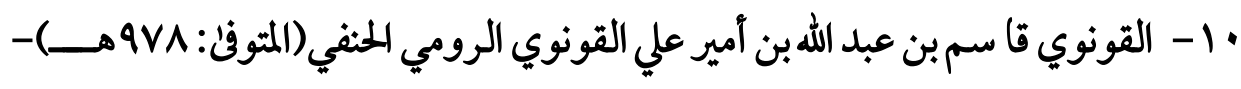

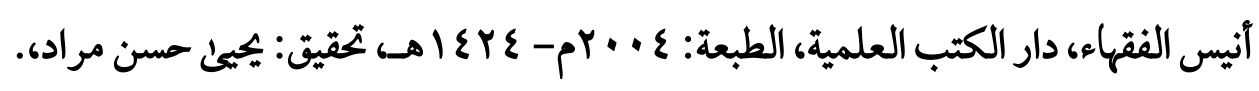

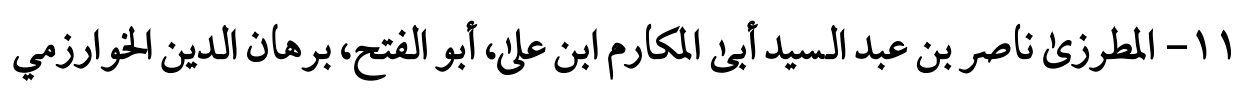
المطرزئ(المتوفن: · لآهـ)- المغرب دار الكتاب العربي.

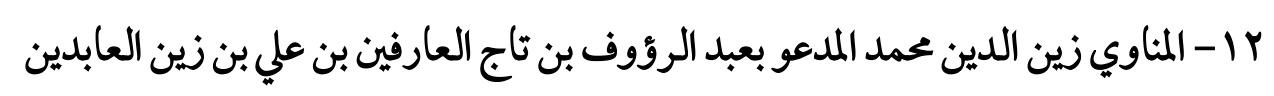

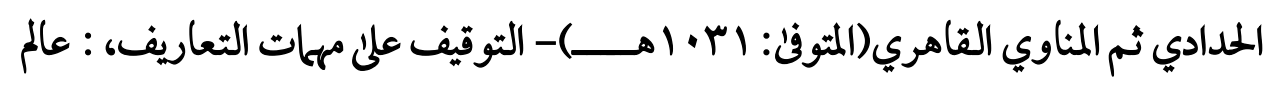

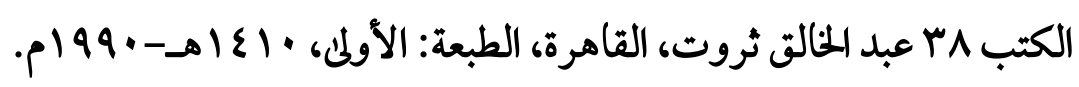

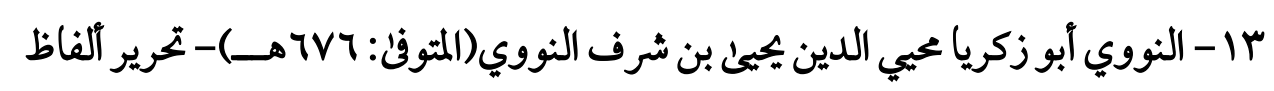

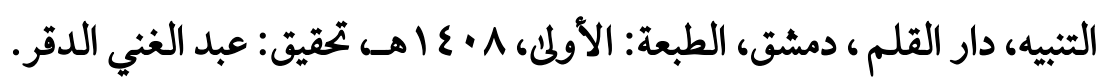

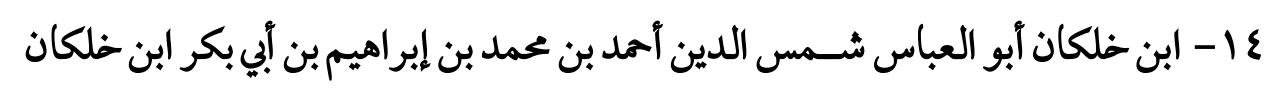

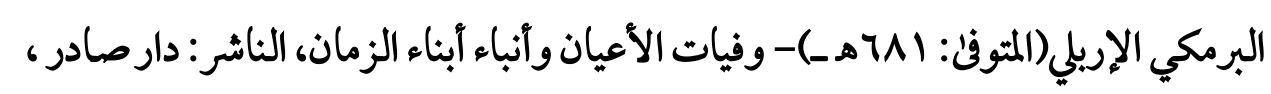

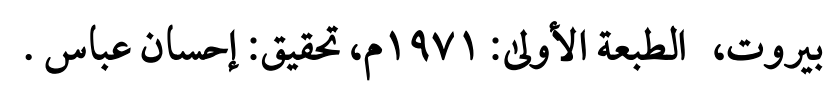

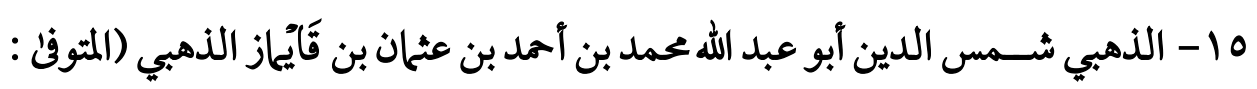

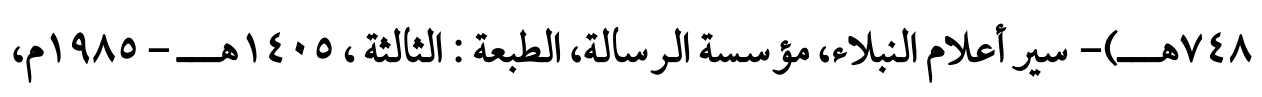
تحقيق: بجموعة من المحققين بإشراف الشيخ شعيب الأرناؤوط.

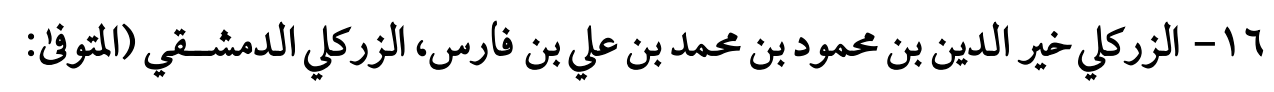

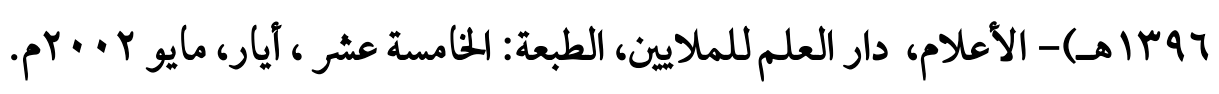


$-111 \varepsilon-$ 